\title{
USE OF A FISH TRANSPORTATION BARGE FOR INCREASING RETURNS OF STEELHEAD IMPRINTED FOR HOMING
}

Final Report

By

Jerrel R. Harmon

and

Emil Slatick

For

U.S. Department of Energy

Bonneville Power Administration

Division of Fish and Wildlife

P.O. Box 3621

Portland, Oregon 97208

Project 82-2

Contract DE-A179-83BP39643

Coastal Zone and Bstuarine Studies Division

Northwest Fisheries Science Center

National Marine Fisheries Service

National Oceanic and Atmospheric Administration

2725 Montlake Boulevard East

Seattle, Washington 98112-2097

August 1989 


\section{ABSTRACT}

The objective of this 7-year National Marine Fisheries Service study, which began in 1982, was to determine if transporting juvenile steelhead (Oncorhynchus mykiss) by truck and barge from Dworshak National Fish Hatchery (NFH), on the Clearwater River, to a release site on the Columbia River below Bonneville Dam would result in increased returns of adults to the various fisheries and to the hatchery homing site.

During 1982 and 1983, over 500,000 marked juvenile steelhead were serially released as controls from the hatchery or barged as test fish to below Bonneville Dam. Recoveries of marked adults to various recovery sites are complete.

Fish released in 1983 showed a stronger homing ability and more rapid upstream migration than test fish released in 1982. Most adults from both control and test releases in 1983 and control releases in 1982 migrated a considerable distance upstream and overwintered in the Snake and Clearwater Rivers--behavior similar to Clearwater River fish previously transported from Lower Granite Dam. In contrast, many of the adults from test releases in $\mathbf{1 9 8 2}$ failed to migrate upstream during the fall, overwintered in the Columbia River, and migrated upstream the following spring.

Survival of control fish released at Dworshak NFH in late April 1982 was substantially higher than survival of those released in mid-May. Survival and homing of control fish released in late April and early May 1983 were over 10 times that for fish released in late May.

Return of adults from normal hatchery releases in 1982 was the highest ever observed at Dworshak NFH. The lower recovery rate from 1983 releases more nearly represented the typical return to the hatchery. Higher survival in 1982 may have resulted because an estimated $57 \%$ of the control fish were collected at the juvenile collector dams and received the survival enhancement of barging to below Bonneville 
Dam as part of the Corps of Engineers' transport operations. In contrast, only 29\% of the control fish were given that assist in 1983.

Survival of fish transported from the hatchery in 1983 was significantly enhanced as indicated by the approximate 4:1 transport to control ratio observed at Bonneville Dam and in the fall Zone 6 Tribal fishery near Bonneville Dam. Less survival enhancement was noted in returns from fish transported from the hatchery in 1982. This may have resulted because of the abnormally high rate of return of control fish resulting from the large numbers transported from Lower Granite Dam in 1982 as part of the Corps of Engineers' transport operations. Actual transport benefit may have been comparable since the rates of recovery of test fish at all sampling sites were similar for both 1982 and 1983 releases.

We concluded that fish which were transported to below Bonneville Dam in late April or early May had the highest returns and that transportation in future years during that time has the potential for increasing returns of Dworshak NFH steelhead to Columbia River fishing locations and to the hatchery. 
CONTENTS

PAGE

INTRODUCTION $\ldots \ldots \ldots \ldots \ldots \ldots \ldots \ldots \ldots \ldots \ldots \ldots$

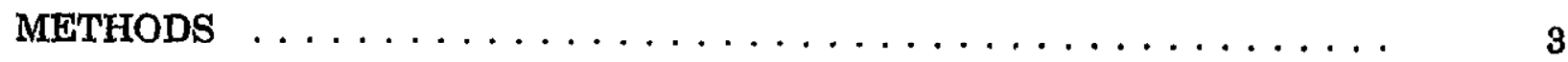

Juvenile Marking and Experimental Design . . . . . . . . . . . . 3

Juvenile Fish Health and Smoltification . . . . . . . . . .

Recapture of Smolts at Dams and in the Estuary . . . . . . . . . . 7

Adult Collection Facilities at Dams . . . . . . . . . . . . . . 8

Adult Recoveries in Fisheries and Hatcheries . . . . . . . . . . . . . 9

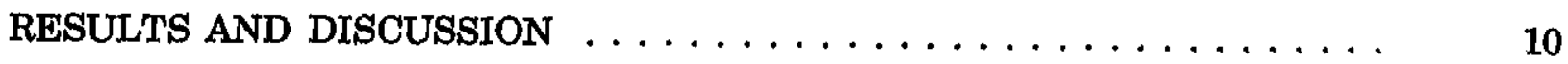

Juvenile Fish Health and Smoltification . . . . . . . . . . . 10

Recapture of Smolts at Dams and in the Estuary . . . . . . . . . . 11

Adult Recoveries $\ldots \ldots \ldots \ldots \ldots \ldots \ldots \ldots \ldots \ldots$

Survival and Homing of Control Groups . . . . . . . . . . 17

1982 releases $\ldots \ldots \ldots \ldots \ldots \ldots \ldots \ldots \ldots \ldots \ldots$

1983 releases $\ldots \ldots \ldots \ldots \ldots \ldots \ldots$

Survival and Homing of Test Groups ............... 21

1982 releases $\ldots \ldots \ldots \ldots \ldots \ldots \ldots \ldots \ldots \ldots \ldots \ldots$

1983 releases $\ldots \ldots \ldots \ldots \ldots \ldots \ldots \ldots \ldots \ldots \ldots \ldots$

Ocean Recoveries $\ldots \ldots \ldots \ldots \ldots \ldots \ldots \ldots \ldots \ldots$

SUMMARY AND CONCLUSIONS $\ldots \ldots \ldots \ldots \ldots \ldots \ldots \ldots$

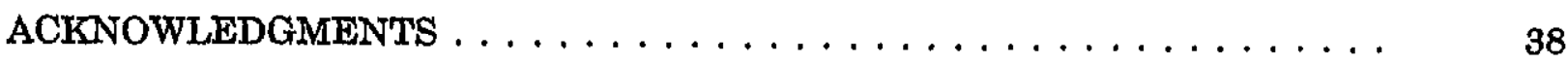

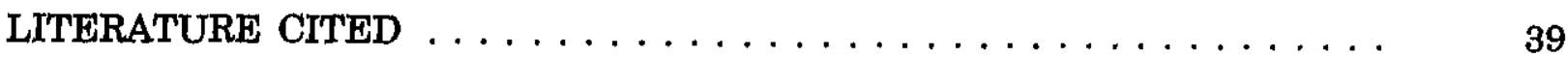

APPENDIX 1 - Data Summaries

APPENDIX 2 - A Report on the Health Status of Selected Groups of Brood Year 1981 Steelhead Trout (Salmo gairdneri)

Raised at the Dworshak National Fish Hatchery

APPENDIX 3 - A Report on the Health Status of Dworshak National Fish Hatchery Steelhead Trout (Salmo gairdneri) used in the National Marine Fisheries Service Transportation-Homing Study (Production Year 1982-1983) 


\section{INTRODUCTION}

The National Marine Fisheries Service (NMFS) conducted a 7-year study (1982-88) in cooperation with the Bonneville Power Administration (BPA) to determine if transporting juvenile steelhead (Oncorhynchus mykisa) smolts from Dworshak National Fish Hatchery (NFH), on the Clearwater River, past eight dams and reservoirs to a release point below Bonneville Dam on the Columbia River would increase returns of adults to the hatchery and various fisheries (Fig. 1).

Impetus for the study came from a test conducted in 1978 at Dworshak NFH in which substantially more adult steelhead returned to the hatchery and nearby sport fishing areas from juveniles that were trucked from the hatchery and then barged to release sites downstream from Bonneville Dam than returned from smolts trucked from the hatchery to below Bonneville Dam or released at the hatchery to migrate downriver on their own volition (Slatick et al. 1982).

Slatick's data suggested that transportation of juveniles from Dworshak NFH could enhance returns of adults to the hatchery and to the sport fishery in the Clearwater River; however, this supposition was based on only one release group at one time. Before implementing such a transportation program, management agencies wanted to know whether steelhead smolts transported throughout a 30- to 40-day period in April and May would return in greater numbers than nontransported smolts. The present study was designed to provide the needed information.

The primary objective of our study was to determine if steelhead reared and imprinted at Dworshak NFH; transported by truck to a transfer site near Lewiston, Idaho; transferred into a barge; and transported to a release site in the Columbia River downstream from Bonneville Dam would return as adults to the hatchery and to the various fisheries in greater numbers than fish released directly into the river at the hatchery. We also investigated the differences in survival and homing of fish in 


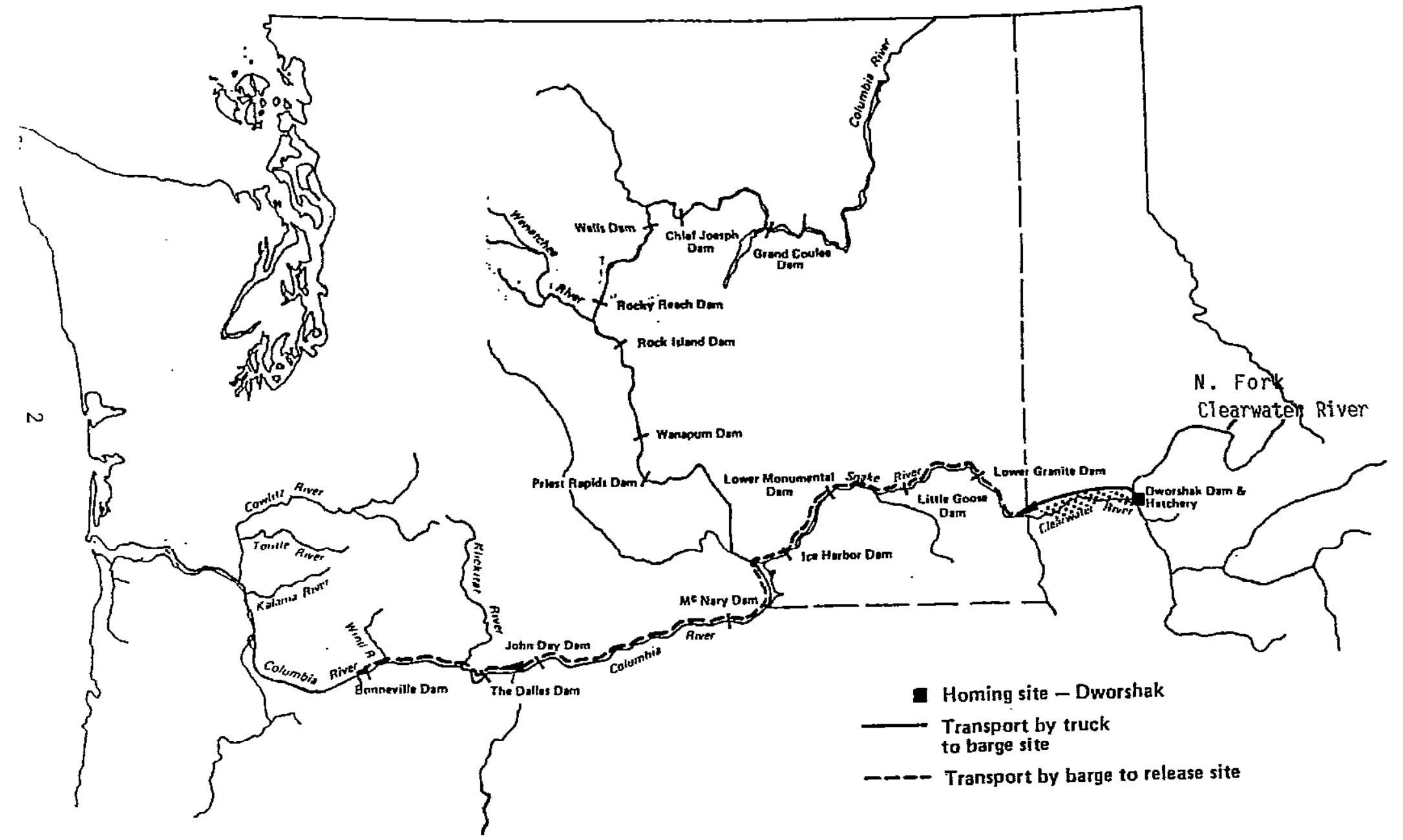

Figure 1.--Study area relevant to the 1982 and 1983 Transport-Homing Study at Dworshak Nationa1 Fish Hatchery. 
relation to the time of release. The physiological condition of the smolts at the time of release was also monitored.

\section{METHODS}

\section{Juvenile Marking and Experimental Design}

From 23 February to 12 March 1982 we marked eight geparately identifiable groups of about 30,000 steelhead each (five test and three control groups) (Table 1). Two treatment groups were released with the first control group on 19 April. Treatment and control groups were also released on 30 April and 19 May. A final treatment group was released on 31 May. In the interest of marking fewer fish and to avoid an artificially late release at the hatchery, no control group was released with the last test. All fish (progeny of Egg Take \#8 in spring 1981) were taken from eight ponds in System II (a reuse water system) at Dworshak NFH. In total, 252,079 steelhead were injected with a coded magnetic wire tag (CWT) and marked with an adipose fin excision. The fish were also externally marked with a freeze brand so their progress as juveniles and as returning adults could be monitored at key sampling sites along their migration route without sacrificing the fish to read the CWTs.

Test and control groups (except T1A) were reared on reuse water in System II at $8.9^{\circ} \mathrm{C}$ until 15 April, when the water temperature was reduced to ambient $\left(5.6^{\circ} \mathrm{C}\right)$ for 5 days. On 20 April, System II was switched from reuse to raw North Fork Clearwater River water at $5.6^{\circ} \mathrm{C}$.

Fish for Test T1A were reared on reuse water until 13 April when they were pumped from the reuse water pond $\left(8.9^{\circ} \mathrm{C}\right)$ in System II to raw North Fork Clearwatex River water $\left(4.4^{\circ} \mathrm{C}\right)$ in a pond in System III. They were then held for 6 days before transport on 19 April to a barge at Lewiston. Pumping of this test group to an alternate pond duplicated the successful test treatment in the 1978 Dworshak NFH experiment (Slatick et al. 1982). 
Table 1.--Juvenile steelhead marked in 1982 at Dworshak National Fish Hatchery.

\begin{tabular}{|c|c|c|c|c|c|c|}
\hline Treatment & $\begin{array}{l}\text { Coded wire } \\
\text { tag code }\end{array}$ & Brand & $\begin{array}{l}\text { Marked } \\
\text { fish } \\
\text { released }\end{array}$ & $\begin{array}{l}\text { Unmarked } \\
\text { fish } \\
\text { released }\end{array}$ & $\begin{array}{l}\text { Date released } \\
\text { from } \\
\text { hatchery }\end{array}$ & Treatment \\
\hline $\begin{array}{l}\text { Control } \\
\text { (C1) }\end{array}$ & $28-6-6$ & LAK-8 & 29,888 & 5,888 & $19 \mathrm{Apr}$ & $\begin{array}{l}\text { Releaged as normal hatchery production } \\
\text { into the Clearwater River }\end{array}$ \\
\hline Test (TI) & $28 \cdot 6 \cdot 8$ & RALm4 & 33.012 & 5,207 & $19 \mathrm{Apr}$ & $\begin{array}{l}\text { Trucked from hatchery to Clearwater } \\
\text { River near Lewiston ID, held in barge } \\
\text { for approx. } 16 \text { hours, and barged for } \\
\text { release below Bonneville Dam. }\end{array}$ \\
\hline Test (T1A) & $29.6-7$ & RAL-3 & 32,185 & 4,237 & $19 \mathrm{Apr}$ & $\begin{array}{l}\text { Pumped from System II to raw water in } \\
\text { another raceway and held for } 6 \text { days. } \\
\text { Then trucked from the hatchery to } \\
\text { Clearwater River near Lewiaton, ID, held } \\
\text { in barge approx. } 16 \text { hours, and barged } \\
\text { for releage below Bonneville Dam. }\end{array}$ \\
\hline $\begin{array}{l}\text { Control } \\
\text { (C2) }\end{array}$ & $28-16-4$ & LAK-2 & 31,048 & 3,094 & $30 \mathrm{Apr}$ & $\begin{array}{l}\text { Releaged as normal hatchery } \\
\text { production into the Clearwater River. }\end{array}$ \\
\hline Test (T2) & $28-16-5$ & RAL-2 & 32,811 & 3,776 & $30 \mathrm{Apr}$ & $\begin{array}{l}\text { Trucked from hatohery to Clearwater } \\
\text { River near Lewiston, ID, held in barge } \\
\text { for approx. } \mathbf{1 6} \text { hours, and barged for } \\
\text { release below Bonneville Dam. }\end{array}$ \\
\hline $\begin{array}{l}\text { Control } \\
\text { (C3) }\end{array}$ & $28-16-2$ & LAK-1 & 31,714 & 3,629 & 19 May & $\begin{array}{l}\text { Releaged as normal hatchery } \\
\text { production into the Clearwater River. }\end{array}$ \\
\hline Test (TB) & $23-16-3$ & RAL-1 & 29,456 & 3,686 & 19 May & $\begin{array}{l}\text { Trucked from hatchery to Clearwater } \\
\text { River near Lewiston, ID, held in barge } \\
\text { for approx. } 16 \text { hours, and barged for } \\
\text { release below Bonneville Dam. }\end{array}$ \\
\hline \multirow[t]{2}{*}{ Test (T4) } & $28-16-1$ & RAL-1 & 31,915 & 3.051 & 31 May & $\begin{array}{l}\text { Trucked from hatchery to Clearwater } \\
\text { River near Lewiston, ID, held in barge } \\
\text { for approx. } 16 \text { hours, and barged for } \\
\text { releage below Bonneville Dam. }\end{array}$ \\
\hline & & COTAL & 252,079 & 32,513 & & \\
\hline
\end{tabular}


Test groups were pumped directly into 3,500mgallon fish transport trucks, equipped with oxygen, refrigeration, and recirculation systems, and transported to Lewiston, on the Clearwater River (approximately 40 miles downstream). They were then loaded into a 110,000-gallon fish transport barge equipped with a pumping system which drew water from the river (pass-through system) and held in Clearwater River watex for approximately 16 hours. The barge then traveled downstream with stops at Lower Granite, Little Goose, and McNary Dams to load fish as part of the transport program operated by the U.S. Army Corps of Engineers (COE) (Fig. 1) (Basham et al. 1983). Fish were released during darkness into the Columbia River downstream from Bonneville Dam at Skamania Light [River Mile (RM) 140].

During 1983, eight separate groups of steelhead (about 30,000 per groupm251,491 total) were marked as in 1982 (Table 2). Marked fish were from eight ponds in System II. Fish from these ponds were progeny of fish spawned during a 2-week period in spring 1982 (Egg Takes 5 and 6).

Prior to 1981, the normal hatchery production smolts were pumped from the hatchery into the North Fork of the Clearwater River. In 1981, approximately 50\% of the hatchery production was pumped to the North Fork while the other $50 \%$ was released by gravity flow to the main stem of the Clearwater River. After 1981, all hatchery production (except experimental fish) was released by gravity flow to the main stem of the Clearwater River.

Due to the low number of 1-ocean age steelhead that returned to Dworshak NFH in spring 1983 (from 1981 smolt releases), there was a concern that some of the fish released in the main stem may have bypassed the hatchery and strayed upstream. After consultation with appropriate fisheries agencies, BPA, and statisticians, we pumped one of our originally scheduled barged groups of marked fish to the North Fork as a second control group in the second serial release (a control group was also released into the main stem of the Clearwater River). Reducing the number of serial 
Table 2.--Juvenile steelhead marked in 1983 at Dworshak National Fish Hatchery.

\begin{tabular}{|c|c|c|c|c|c|c|}
\hline Treatment & $\begin{array}{l}\text { Coded wire } \\
\text { tag code }\end{array}$ & Brand & $\begin{array}{c}\text { Marked } \\
\text { fish } \\
\text { released }\end{array}$ & $\begin{array}{l}\text { Unmarked } \\
\text { fluh } \\
\text { released }\end{array}$ & $\begin{array}{l}\text { Date released } \\
\text { from } \\
\text { hatchery }\end{array}$ & Treatment \\
\hline $\begin{array}{l}\text { Control } \\
\text { (C1) }\end{array}$ & $23-16-38$ & LAW-1 & 38,178 & 113 & $20 \mathrm{Apr}$ & $\begin{array}{l}\text { Released as normal hatohery production into } \\
\text { the mainstem Clearwater River. }\end{array}$ \\
\hline Tent (T1) & $28-16-40$ & RAF-1 & 30,341 & 165 & $20 \mathrm{Apr}$ & $\begin{array}{l}\text { Trucked from hatchery to Clearwater River } \\
\text { near Lewiston ID, held in barge for approx. } \\
16 \text { hours, and barged for release below } \\
\text { Bonneville Dam. }\end{array}$ \\
\hline Test (T1A) & 28-16-39 & RAZ-1 & 28,658 & 138 & $20 \mathrm{Apr}$ & $\begin{array}{l}\text { Pumped to another pond and held for } \\
7 \text { daye; then truaked from the hatchery } \\
\text { to Clearwater River near Lewigton, ID; } \\
\text { held in barge approx. } 16 \text { hours; and } \\
\text { barged for release below Bonneville Dam. }\end{array}$ \\
\hline $\begin{array}{l}\text { Control } \\
\text { (C2) }\end{array}$ & $28-16-16$ & LAW-2 & 32,236 & 8,128 & 3 May & $\begin{array}{l}\text { Released as normal hatchery production into } \\
\text { the Clearwater River. }\end{array}$ \\
\hline $\begin{array}{l}\text { Control } \\
\text { (C2A) }\end{array}$ & 28-16-10 & RAF.3 & 31,956 & 1,978 & 9 May & $\begin{array}{l}\text { Released into the North Fork Clearwater } \\
\text { River. }\end{array}$ \\
\hline Test (T2) & 28-16-17 & RAF-2 & 92,456 & 2,242 & 3 May & $\begin{array}{l}\text { Trucked from hatchery to Clearwater River } \\
\text { near Lewloton, ID, held in barge for approx. } \\
16 \text { hour, and barged for releage below } \\
\text { Bonnerille Dam. }\end{array}$ \\
\hline $\begin{array}{l}\text { Control } \\
\text { (C3) }\end{array}$ & $23-16-20$ & RAF-4 & 80,751 & $21 \theta$ & 25 May & $\begin{array}{l}\text { Released as normal hatohery produotion into } \\
\text { the Clearwater River. }\end{array}$ \\
\hline Teat (T3) & $28-16-18$ & LAW-3 & 31,906 & 2.708 & 24 May & $\begin{array}{l}\text { Trucked from hatchery to Clearwater River } \\
\text { near Lewiston, ID, held in brage for } \\
\text { approx. } 16 \text { 'hours, and barged for release } \\
\text { below Bonneville Dam. }\end{array}$ \\
\hline \multicolumn{3}{|c|}{ TOTAL } & 251,491 & 15,081 & & \\
\hline
\end{tabular}


releases from four to three resulted in slightly longer intervals between releases to bracket the original time frame. Release dates were 20 April and 3 and 24-25 May (Table 2).

Test and control groups were reared on reuse water in System II at $8.9^{\circ} \mathrm{C}$. On 6 April 1983, the water was changed from reuse to raw North Fork Clearwater River water at $4.4^{\circ} \mathrm{C}$. Fish from Test T1A were pumped to another pond in System II on 13 April 1983 and held for 7 days before transport.

Test groups were loaded and transported in the same sequence as in 1982.

Juvenile Fish Health and Smoltification

During 1982, the general health and status of smoltification of the experimental groups were monitored from mid-March until their release from the hatchery. This portion of the project was carried out by the University of Idaho (UI), Moscow, Idaho (Appendix 2).

During 1983, the general health and status of smoltification of the experimental groups were monitored from March until their release from the hatchery. This portion of the project was carried out by the U.S. Fish and Wildlife Service (USFWS), Ahsahka, Idaho (Appendix 3).

Recapture of Smolts at Dams and in the Estuary

Following release from the barge or the hatchery, juveniles were recovered at dams or in the estuary while enroute to the ocean. Other research projects provided smolt recovery data at dams (Sims et al. 1983) and from the estuary (Dawley et al. 1983, 1984). These data provided the means to estimate the numbers of experimental fish passing dams or collected at dams and transported in the COE operation. 


\section{Adult Collection Facilities at Dams}

Since August 1983, we monitored adult steelhead returning to 1) the adult collection facilities at Bonneville, McNary, and Lower Granite Dams; 2) the sport fishery on the Columbia, Snake, and Clearwater Rivers; 3) the Zone 6 and Clearwater River Indian fisheries; and 4) the Dworshak NFH homing site.

Adult collection facilities at Bonneville and McNary Dams on the Columbia River and Lower Granite Dam on the Snake River were operated during the fall from 1983 through 1987. The sampling site at Lower Granite Dam was also monitored during the spring, since many Dworshak NFH steelhead overwinter in the Snake River below Lower Granite Dam before continuing their migration to the Clearwater River. At Bonneville and McNary Dams, the sampling sites were located in the north fishways only, therefore less than 25\% of the Snake River steelhead population was sampled. At Lower Granite Dam, virtually the entire Snake River run was sampled.

These in-river collection facilities provided separation of tagged fish from the untagged adult population. Fish entering the trapping area passed over a false weir and slid downward through a detection coil into a smooth horizontal trough. If the fish was tagged, the magnetic field was interrupted and a signal transmitted to a solenoid indirectly operating a gate that shunted tagged fish to a holding area (Durkin et al. 1969; Ebel 1974). Fish that were not tagged were automatically diverted back to the main fishway. Tagged fish were removed from the holding area with a dipnet, anesthetized in a tank, measured, jaw tagged, and identified by brand. By reading the freeze brand applied when the fish were juveniles, fish from individual treatment groups were identified. Fish were then allowed to recover in fresh water before release. These fish were recovered in the various fisheries and at Dworshak NFH (Gilbreath et al. 1976; Slatick 1976). Some fish were recovered more than once; recaptured fish were included in all data summaries (e.g., at Lower Granite Dam and Dworshak NFH). 


\section{Adult Recoveries in Fisheries and Hatcheries}

Sampling in the sport and Indian fisheries began during fall 1983 and continued through 1987. Recoveries were also monitored at Dworshak NFH each spring from 1983 through 1987.

The area with the greatest fishing pressure (Clearwater River and the Snake River near its confluence with the Clearwater River) received the majority of our sampling effort in the sport fishery. Recoveries from sport fishermen were in the form of jaw tags and fish snouts containing coded wire tags.

Most recoveries from the Columbia River Zone 6 fall and winter Indian fishery came from sampling by the Oregon Department of Fish and Wildlife and the Washington Department of Wildlife. We also received recoveries from tribal members fishing the Clearwater River in Idaho.

Adult steelhead entered Dworshak NFF through a fish ladder and were held in adult holding ponds until maturation. Generally, hatchery personnel checked each fish weekly. Mature fish were killed, spawned, and checked for CWTs. All snouts from tagged fish were retained for extraction and decoding of the CWT.

We used discrete multivariate analysis to statistically compare test and control treatments (Bishop et al. 1975). In this procedure, the treatments were structured in contingency tables. The G-statistic was used to test for significance which was established at $\mathrm{P}<0.05$, df $=1$ (Sokal and Rohlf 1981).

In this report, treatment benefit (barge transport) is expressed by test to control (T/C) ratios of adult recoveries at any site. Further, survival enhancement is based on T/C ratios of adult recoveries in the lower river (Bonneville Dam and the Zone 6 Tribal fishery) (e.g., if the $T / C$ ratio was 3:1, survival of transported fish was considered to be three times that of control fish). The lower river sites were used as a maximum survival index because adverse effects to the population such as fishing harvest and homing disruptions due to transport would be minimal at that point in their upstream 
migration. The proportion of fish in each test release that did not receive a homing imprint is based on the difference in the T/C ratios between fish returning to the lower river and fish returning to successive sampling sites on their return trip to the hatchery. Thus, if the T/C ratio was 3:1 at Bonneville Dam and 1:1 at the hatchery, $67 \%$ of the test fish were considered to have failed to receive an adequate homing imprint to enable them to return to the hatchery.

T/C ratios stated must be considered minimum benefits because an estimated 57 and $29 \%$ of the control releases in 1982 and 1983, respectively, received additional benefit from another transportation program. Each year since 1981, the COE has operated a smolt transport program whereby fish are collected at Lower Granite, Little Goose, and McNary Dams and subsequently transported to below Bonneville Dam. The fish are released at the same site we used in the experiment (RM 140).

\section{RESULTS AND DISCUSSTON}

\section{Juvenile Fish Health and Smoltification}

The investigators from the UI concluded, based on physical, physiological, and histopathological observations, that "there was no reason to assume that the fish sampled from 1982 releases were anything other than clinically healthy" (Appendix 2).

Juvenile smoltification analyses based on gill $\mathrm{Na}^{+}-\mathrm{K}^{+}$ATPase levels were also reviewed in the UI report. Unfortunately, two sample groups of tissue were treated erroneously, resulting in questionable data which compromises conclusions drawn from $\mathrm{Na}^{+}-\mathrm{K}^{+}$ATPase studies in 1982.

In 1983 , based on the same physical, physiological, and histopathological observations as in 1982, investigators from the USFWS concluded that the fish in all groups were in good health and well advanced in smoltification at time of release. The major difference between groups was a higher incidence of gill and nasal epithelial hyperplasia in fish examined from late April to early May. Fish examined in mid to 
late May were normal. In early April, hatchery management switched from reuse water to raw water with a reduced temperature; this may have aided in the repair of the damaged tissue.

Gill $\mathrm{Na}^{+}-\mathrm{K}^{+}$ATPase activity increased during the monitoring period from 2 March to 24 May 1983 (Fig. 2). The last control group (C3) was used as a baseline for comparison with test and other control releases. The G-statistic with significance established at $P<0.05, \mathrm{df}=1$ was used for statistical comparisons. Release Groups T1A, C2, C2A, and T3 showed no significant differences from the baseline level. Levels for Groups C1 and T2 were significantly lower, and the level from Group T1 was significantly higher, than baseline levels.

Although statistical tests in three groups showed deviation from baseline $\mathrm{Na}^{+}-\mathrm{K}^{+}$ ATPase levels, releases of control and test groups occurred during the period of high $\mathrm{Na}^{+}-\mathrm{K}^{+}$ATPase activity--within the range expected at Dworshak NFH. We should point out that although $\mathrm{Na}^{+}-\mathrm{K}^{+}$ATPase activity was still elevated when groups C3 and T3 were released, the activity was definitely declining. Direct observations and analyses conducted by the physiologist and hatchery pathologist suggested that all groups were well smolted. The report on fish health and smoltification for 1983 is presented in Appendix 3.

Recapture of Smolts at Dams and in the Estuary

Sims et al. (1983) estimated that a high percentage of the control releases reached Lower Granite Dam in 1982, and that they were subsequently transported (Table 3). For the three control releases, estimated survival of steelhead to Lower Granite Dam was near 100\%, and 57\% were transported from Lower Granite, Little Goose, or McNary Dams. Survival of the nontransported controls to John Day Dam was only $2.6 \%$, based on estimated passage of 2,390 fish at John Day Dam out of the 39,497 marked fish that were not collected and transported (Table 3). The apparent 


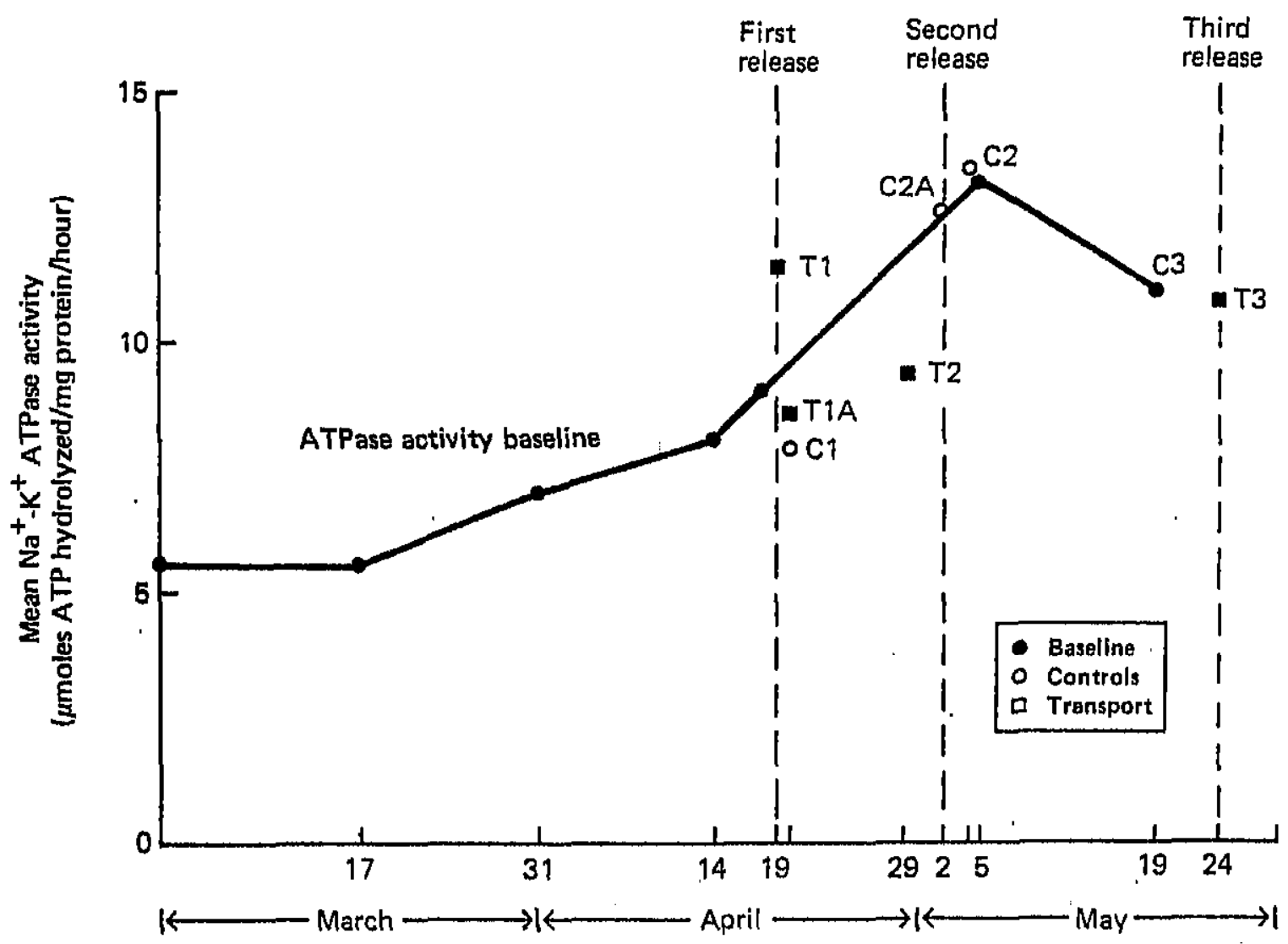

Figure 2.--Na ${ }^{+}-\mathrm{K}^{+}$ATPase activity for test steelhead reared at Dworshak National Fish Hatchery and released in 1983. Control group (C3) was used as a baseline for comparison with transport and other control groups on release dates. 
Table 3.--Estimated numbers of marked steelhead from control releases at Dworshak National Fish Hatchery that were either transported or migrated downriver of their own volition and survived to John Day Dam in 1982 (Sims et al. 1983).

\begin{tabular}{|c|c|c|c|c|c|c|}
\hline \multirow[b]{2}{*}{ Control } & \multirow{2}{*}{$\begin{array}{l}\text { Tag } \\
\text { code }\end{array}$} & \multirow{2}{*}{$\begin{array}{l}\text { Number } \\
\text { released }\end{array}$} & \multicolumn{2}{|c|}{$\begin{array}{c}\text { Collected } \\
\text { and transported" }\end{array}$} & \multicolumn{2}{|c|}{$\begin{array}{l}\text { Volitional migrants } \\
\text { at John Day Dam }\end{array}$} \\
\hline & & & Number & Percent & Number & Percent \\
\hline$c-1$ & $23-6-6$ & 29,838 & 19,559 & 65.6 & 1,000 & 3,4 \\
\hline$c-2$ & $23-16-4$ & 31,048 & 14,986 & 48.3 & 595 & 1.9 \\
\hline$C-3$ & $23-16-2$ & 31,714 & 18,558 & 58.5 & 795 & 2.5 \\
\hline Combined & - & 92,600 & 53,103 & 57.3 & 2,390 & 2.6 \\
\hline
\end{tabular}

- Transported from Lower Granite, Little Goose, or MoNary Dams to a release site in the Columbia River below Bonneville Dam. 
low survival of controls to John Day Dam coupled with the large number of controls that received the benefits of transportation, means that most of the controls that returned as adults were most likely those previously transported as juveniles during the program operated by the COE.

During 1983, 37,244 (29.1\%) fish from the control releases were transported from Lower Granite, Little Goose, or McNary Dams, and 13,477 (14.8\%) of the controls survived to John Day Dam (Table 4). The number of fish from control releases estimated to have reached the lower river in each year was comparable--55,493 in 1982 and 50,721 in 1983.

A summary of recoveries from estuary sampling in 1982 at Jones Beach, Oregon, is presented in Table 5. Dawley et al. (1983) indicated that recoveries of fish from test and control releases of the third and fourth groups (released on 19 and 31 May) were substantially higher than from the earlier releases on 19 and 30 April.

Recoveries from estuary sampling in 1983 at Jones Beach showed a similar pattern (Table 5). Dawley et al. (1984) stated that recoveries were also highest from the later releases. For the last release (24 and 25 May), recoveries were substantially higher from the test group than from the control group, whereas recovery of test and controls were similar in the first and second treatment groups.

The data from estuary sampling show no correlation with subsequent adult recoveries. Data from adult recoveries show substantially higher returns from smolts released in late April and early May. Adult recoveries from the last releases (late May) were dismal. These data are analyzed and discussed in more detail below.

\section{Adult Recoveries}

There were 12,066 recoveries from 1982 and 1983 test and control releases, including 7,324 fish from 1982 releases and 4,742 fish from 1983 releases. A summary of recoveries for each experimental group is presented in Appendix Tables 1-1 through 
Table 4.--Estimated numbers of marked steelhead from control releases at Dworshak National Fish Hatchery that were either transported or migrated downriver of their own volition and survived to John Day Dam in 1983 (Sims et al. 1983).

\begin{tabular}{|c|c|c|c|c|c|c|}
\hline \multirow[b]{2}{*}{ Control } & \multirow{2}{*}{$\begin{array}{l}\text { Tag } \\
\text { code }\end{array}$} & \multirow{2}{*}{$\begin{array}{l}\text { Number } \\
\text { released }\end{array}$} & \multicolumn{2}{|c|}{$\begin{array}{c}\text { Collected } \\
\text { and transported }\end{array}$} & \multicolumn{2}{|c|}{$\begin{array}{c}\text { Survival of } \\
\text { controls } \\
\text { to John Day Dam }\end{array}$} \\
\hline & & & Number & Percent & Number & Percent \\
\hline$C-1$ & $23-16-38$ & 33,178 & 9,304 & 28.0 & 5,864 & 24.6 \\
\hline $\mathrm{C}-2$ & $23-16-16$ & 32,236 & 8,181 & 25.4 & 2,155 & 9.0 \\
\hline$C-2 A$ & $23-16-19$ & 31,956 & 9,719 & 30.4 & 1,716 & 7.7 \\
\hline$c-3$ & $23-16-20$ & 30,751 & 10,040 & 32.6 & 3,742 & 18.1 \\
\hline Combined & - & 128,121 & 37.244 & 29.1 & 13,477 & 14.8 \\
\hline
\end{tabular}

Transported from Lower Granite, Little Goose, or McNary Dams to a release site in the Columbia River below Bonneville Dam. 
Table 5.--Marked steelhead from Dworshak National Fish Hatchery that were recovered at Jones Beach, Oregon, in the Columbia River estuary in 1982 and 1983.

\begin{tabular}{|c|c|c|c|c|}
\hline Treatment & $\begin{array}{l}\text { Coded wire } \\
\text { tag code }\end{array}$ & $\begin{array}{l}\text { Number } \\
\text { recovered" }\end{array}$ & $\begin{array}{c}\text { Percent } \\
\text { recapture } \\
\text { of juvenile } \\
\text { released }\end{array}$ & $\begin{array}{l}\text { Date of } \\
\text { median } \\
\text { recapture }\end{array}$ \\
\hline \multicolumn{5}{|l|}{1982 Releases } \\
\hline $\begin{array}{l}\text { Control (C1) } \\
\text { Test (T1) } \\
\text { Tegt (T1A) }\end{array}$ & $\begin{array}{l}23-6-6 \\
23-6-8 \\
23-6-7\end{array}$ & $\begin{array}{l}14 \\
23 \\
25\end{array}$ & $\begin{array}{l}0.05 \\
0.07 \\
0.08\end{array}$ & $\begin{array}{l}11 \text { May } \\
24 \text { Apr } \\
25 \text { Apr }\end{array}$ \\
\hline $\begin{array}{l}\text { Control (C2) } \\
\text { Test (T2) }\end{array}$ & $\begin{array}{l}23-16-4 \\
23-16-5\end{array}$ & $\begin{array}{l}22 \\
14\end{array}$ & $\begin{array}{l}0.07 \\
0.04\end{array}$ & $\begin{aligned} 20 & \text { May } \\
5 & \text { May }\end{aligned}$ \\
\hline $\begin{array}{l}\text { Control (C3) } \\
\text { Test (T3) }\end{array}$ & $\begin{array}{l}23-16-2 \\
23-16-3\end{array}$ & $\begin{array}{r}112 \\
69\end{array}$ & $\begin{array}{l}0.35 \\
0.23\end{array}$ & $\begin{array}{l}29 \text { May } \\
23 \text { May }\end{array}$ \\
\hline Test (T4) & $23-16-1$ & 126 & 0.40 & 4 Jun \\
\hline \multicolumn{5}{|l|}{1983 Releases } \\
\hline $\begin{array}{l}\text { Control (C1) } \\
\text { Test (T1) } \\
\text { Test (T1A) }\end{array}$ & $\begin{array}{l}23-16-38 \\
23-16-40 \\
23-16-39\end{array}$ & $\begin{array}{l}68 \\
76 \\
56\end{array}$ & $\begin{array}{l}0.21 \\
0.25 \\
0.20\end{array}$ & $\begin{array}{l}15 \text { May } \\
25 \text { Apr } \\
25 \text { Apr }\end{array}$ \\
\hline $\begin{array}{ll}\text { Control } & \text { (C2) } \\
\text { Control } & \text { (C2A) } \\
\text { Test (T2) }\end{array}$ & $\begin{array}{l}23-16-16 \\
23-16-19 \\
23-16-17\end{array}$ & $\begin{array}{r}88 \\
95 \\
100\end{array}$ & $\begin{array}{l}0.27 \\
0.30 \\
0.31\end{array}$ & $\begin{aligned} 18 & \text { May } \\
21 & \text { May } \\
7 & \text { May }\end{aligned}$ \\
\hline $\begin{array}{l}\text { Control (C3) } \\
\text { Test (T3) }\end{array}$ & $\begin{array}{l}23-16-20 \\
23-16-18\end{array}$ & $\begin{array}{l}142 \\
249\end{array}$ & $\begin{array}{l}0.46 \\
0.78\end{array}$ & $\begin{aligned} 5 & \text { Jun } \\
28 & \text { May }\end{aligned}$ \\
\hline
\end{tabular}

N Numbers adjusted for catch effort. 
1-8 (1982 releases) and 1-9 through 1-16 (1983 releases). The total number of fish and the percent return of adults from juvenile releases are not directly comparable between sampling sites because of different sampling rates. However, T/C ratios are directly comparable between experimental groups within and among sampling sites.

Survival and Homing of Control Groups

1982 releaseg--Table 6 shows the percentage of adults captured at Bonneville, McNary, and Lower Granite Dams; in the Indian and sport fisheries; and at the Dworshak NFH homing site from juveniles released as controls from Dworshak NFH in 1982.

Adults sampled at Bonneville Dam indicate that fish released from the second control group (30 April) had a higher recovery (0.71\%) than fish released from either the first control group (19 April, 0.57\%) or the third control group (19 May, 0.42\%) (Table 6).

Control fish intercepted in the Indian fishery had the same recovery $(0.52 \%)$ from the first and second releases. Recoveries from the third release were much lower $(0.37 \%)$.

The sampling rate at McNary Dam was low; therefore, the number of recoveries were much lower than from the Indian fishery. Recoveries from the first group were highest $(0.07 \%)$, whereas recoveries from the second and third control groups were 0.03 and $0.04 \%$, respectively.

Recoveries at Lower Granite Dam of the first control release were slightly higher (1.64\%) than the second release (1.61\%) and considerably higher than the third release (1.04\%). All fish passing Lower Granite Dam were sampled, and the overall higher recoveries reflect this higher sampling rate. 
Table 6.--Comparison of adult steelhead from three groups of juveniles released into the main stem of the Clearwater River from Dworshak National Fish Hatchery in 1982.

\begin{tabular}{lccc}
\hline $\begin{array}{l}\text { Recovery } \\
\text { locations }\end{array}$ & $\begin{array}{c}\text { Percent of juveniles recovered as adults } \\
\text { release }\end{array}$ \\
\hline Bonneville Dam & 0.57 & $\begin{array}{c}\text { 30 April } \\
\text { release }\end{array}$ & $\begin{array}{c}19 \text { May } \\
\text { release }\end{array}$ \\
Indian fishery & 0.53 & 0.71 & 0.42 \\
McNary Dam & 0.07 & 0.52 & 0.37 \\
Lower Granite Dam & 1.64 & 0.03 & 0.04 \\
Sport fishery & 0.39 & 1.61 & 1.04 \\
Dworshak Hatchery & 0.68 & 0.43 & 0.19 \\
\hline
\end{tabular}

- Results are not comparable between sites because of differences in sampling rate. 
Most of the control fish recovered in the sport fishery were caught in the Snake and Clearwater Rivers. The second control group showed the highest return (0;43\%). Recoveries from the first and third control groups were 0.39 and $0.19 \%$, respectively.

At the Dworshak NFH homing site, returns of control fish were highest for the second release $(0.82 \%)$. Returns from the first and third control groups were 0.68 and $0.40 \%$, respectively.

These data indicate that adult survival from control releases of the first two groups (19 and 30 April) were significantly higher $(P<0.05, \mathrm{df}=1)$ than survival of the third release on 19 May. It should be noted that these recoveries are not indicative of survival of fish passing downstream through the dam complex in 1982 because an estimated $57 \%$ of the fish released as controls had the benefit of transportation from either Lower Granite, Little Goose, or McNary Dams to below Bonneville Dam as part of the COE annual transport program (Harmon and Slatick 1983).

Juvenile sampling in the estuary in 1982 and 1983 indicated the highest recovery from the late May release (Harmon and Slatick 1983, 1984). This suggests that conditions in the estuary or ocean, or the physiological condition of the fish, were not as good in late May as they were earlier in the year. The recovery rate may not be directly indicative of survival because it is possible that late arriving fish moved slower through the estuary due to lower river flows and were caught in larger numbers.

1983 releases--Table 7 shows adult recoveries to the various sites from control releases in 1983. Recoveries were similar from fish released on 20 April and 3 May. However, as with 1982 releases, the recoveries from the last release (25 May) were much lower at all sites.

Two control groups were released at different locations on 3 May to verify that the normal hatchery release site (Clearwater River) for the past several years had not 
Table 7.-.Comparison of adult steelhead from four groups of juveniles released into the main stem or the North Fork of the Clearwater River from Dworshak National Fish Hatchery in 1983.

\begin{tabular}{llccc}
\hline $\begin{array}{l}\text { Recovery } \\
\text { locations }\end{array}$ & $\begin{array}{l}\text { Percent of juveniles recovered as aduits } \\
\text { release }\end{array}$ & $\begin{array}{c}\text { 3 May } \\
\text { release } \\
\text { (Clearwater R.) }\end{array}$ & $\begin{array}{c}\text { 3 May } \\
\text { release } \\
\text { (North Fork) }\end{array}$ & $\begin{array}{c}25 \text { May } \\
\text { release }\end{array}$ \\
\hline Bonneville Dam & 0.13 & 0.07 & 0.10 & 0.01 \\
Indian fishery & 0.19 & 0.13 & 0.24 & 0.01 \\
MoNary Dam & 0.02 & 0.00 & 0.00 & 0.00 \\
Lower Granite Dam & 0.64 & 0.59 & 0.59 & 0.06 \\
Sport fishery & 0.17 & 0.13 & 0.17 & 0.02 \\
Dworshak NFH & 0.29 & 0.28 & 0.30 & 0.02 \\
\hline
\end{tabular}

aesults are not comparable between sites because of differences in sampling rate at each recovery site. 
adversely impacted survival or homing. Recoveries from releases in the Clearwater River and the North Fork Clearwater River showed no significant differences at any site. The nearly identical recoveries to the hatchery $(0.28$ vs $0.30 \%)$ indicate the mainstem release site was as effective as the North Fork release site.

The return of adults to the hatchery from the 20 April and 3 May releases was about $0.3 \%$, similar to the 0.15 to $0.29 \%$ return from smolts released at the hatchery between 1978 and 1981 (W. Miller ${ }^{1}$ ). This was less than half that recorded at the hatchery in 1982. The record high return from 1982 releases was probably a result of the 1) unusually high smolt survival [nearly $100 \%$ survival from the hatchery to Lower Granite Dam in 1982, compared to about 50\% in most years (D. Park $\left.{ }^{2}\right)$, 2) added downriver survival resulting from the increased transportation, and 3) possibly higher ocean survival.

Survival and Homing of Test Groups

1982 releases--Recoveries of test fish to Bonneville Dam varied depending on the time of release of the juveniles. Test to control ratios were 0.8:1 for Test T1 and 0.7:1 for Test T1A released on 19 April (Table 8). In contrast, test fish released on 30 April and 19 May had significantly higher returns than the corresponding controls, indicating better survival of test fish as shown by $\mathrm{T} / \mathrm{C}$ ratios of 1.4:1 and 2.5:1, respectively $(P<0.01, \mathrm{df}=1)$. Returns of test fish released 31 May were poorest, as reflected by a test to control ratio of $0.5: 1$ (test fish were compared to control fish in the third release).

\footnotetext{
${ }^{1}$ W. Miller, U.S. Fish and Wildlife Service, Dworshak Fisheries Assistance Office, Ahsahka, ID 83520. Pers. commun., 1986.

${ }^{2}$ D. Park, National Marine Fisheries Service, Northwest Fisheries Center, 2725 Montlake Blvd. E., Seattle, WA 98112. Pers. commun., 1986.
} 
Table 8.-Recoveries of adult steelhead at Bonneville, McNary, and Lower Granite Dams from juveniles released in spring 1982 from Dworshak National Fish Hatchery.

\begin{tabular}{|c|c|c|c|c|c|c|c|c|c|c|c|c|c|c|c|c|c|}
\hline \multirow[b]{4}{*}{ Treatment } & \multirow{4}{*}{$\begin{array}{l}\text { Date } \\
\text { juveniles } \\
\text { released }\end{array}$} & \multirow{4}{*}{$\begin{array}{l}\text { Number } \\
\text { juveniles } \\
\text { released }\end{array}$} & \multirow{2}{*}{\multicolumn{3}{|c|}{ Bonneville Dam" }} & \multirow{2}{*}{\multicolumn{3}{|c|}{ HcFary Dam" }} & \multicolumn{9}{|c|}{ Lower Granite Dan" } \\
\hline & & & \multirow{2}{*}{\multicolumn{2}{|c|}{ Total }} & \multirow{3}{*}{$\begin{array}{c}\text { Test to } \\
\text { control } \\
\text { ratio }\end{array}$} & & & & \multirow{2}{*}{\multicolumn{2}{|c|}{$\begin{array}{l}\text { Fall retur } \\
\text { Total }\end{array}$}} & & \multirow{2}{*}{\multicolumn{2}{|c|}{ Potal }} & & \multirow{2}{*}{\multicolumn{2}{|c|}{ Totai }} & ms \\
\hline & & & & & & \multicolumn{2}{|c|}{ Total } & \multirow{2}{*}{$\begin{array}{l}\text { Test to } \\
\text { control } \\
\text { ratio }\end{array}$} & & & \multirow{2}{*}{$\begin{array}{l}\text { rest to } \\
\text { control } \\
\text { ratio }\end{array}$} & & & \multirow{2}{*}{$\begin{array}{l}\text { Test to } \\
\text { control } \\
\text { ratio }\end{array}$} & & & \multirow{2}{*}{$\begin{array}{l}\text { Test to } \\
\text { control } \\
\text { ratio }\end{array}$} \\
\hline & & & Number & Percent & & Number & Percent & & Nomber & Percent & & Number & Percent: & & Number & Percent & \\
\hline Control (C1) & $19 \mathrm{Apr}$ & 29,838 & 171 & 0.57 & & 20 & 0.07 & & 387 & 1.30 & & 102 & 0.34 & & 489 & 1.64 & \\
\hline Test (TI) & 19 Арт & 33,012 & 146 & 0.44 & $0.8=1 *$ & 54 & 0.16 & $2.4: 1 * \star$ & 48 & 0.15 & $0.1: 1 * \star$ & 160 & 0.49 & $1.4: 1 \pm *$ & 208 & 0.63 & $0.4: 1 * *$ \\
\hline Test. (T1A) & $19 \mathrm{APr}$ & 32,185 & 122 & 0.38 & $0.7: 1 \pm \star$ & 24 & 0.07 & $1.1=1 \mathrm{~ns}$ & 35 & 0.11 & $0.1=1 * *$ & 112 & 0.35 & $1.0=1 * \star$ & 127 & 0.46 & $0.3=1 * *$ \\
\hline Control (C2) & 30 Apr & 31,048 & 220 & 0.71 & & 10 & 0.03 & & 362 & 1.17 & & 138 & 0.44 & & 500 & 1.61 & \\
\hline Test (T2) & 30 ApI & 32,911 & 322 & 0.98 & $1.4: 1 \pm *$ & 48 & 0.15 & $4.6: 1 \star \star$ & 128 & 0.39 & $0.3: 1 \star \star \star$ & 285 & 0.87 & $2.0: 1 \star \star \star$ & 413 & 1.26 & $0.8: 1 * *$ \\
\hline Control (C3) & 19 May & 31,714 & 133 & 0.42 & & 14 & 0.04 & & 259 & 0.82 & & 71 & 0.22 & & 330 & 1.04 & \\
\hline Test (T3) & 19 May & 29,456 & 313 & 1.06 & $2.5: 1 * \star$ & 37 & 0.13 & $2.9: 1 \star \star$ & 62 & 0.21 & $0.3: 1 \star \star \star$ & 228 & 0.77 & $3.5: 1 * \pm$ & 290 & 0.99 & $1.0=1 \mathrm{~ns}$ \\
\hline Test (T4) & 31 May & 31,915 & 61 & 0.19 & $0.5: 1^{b * *}$ & $\underline{17}$ & 0.05 & $1.2: 1^{b} \mathrm{~ns}$ & 11 & 0.03 & $0.0: 1^{b t t}$ & 69 & 0.22 & $1.0=1^{b} n s$ & 80 & 0.25 & $0.2: 1^{b * k}$ \\
\hline Totals & & 252,079 & 1,488 & & & 224 & & & 1,292 & & & 1,165 & & & 2,457 & & \\
\hline
\end{tabular}

Sampling intensity differed between sites; therefore, only test to control ratios should be used for comparisons.
bince no control group was released with Test T4, it was compared to control c3 to obtain the test to control ratio.

ns = Honsignificant

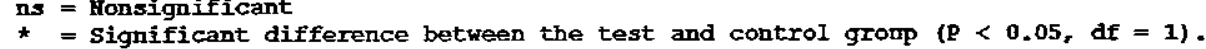

${ }_{* *}=$ Significant difference between the test and control group ( $(\mathrm{P}<0.01$, df $=1$ ). 
Recoveries from McNary Dam showed T/C ratios of 2.4:1 and 1.1:1 for the first release, 4.6:1 for the second release, 2.9:1 for the third release, and 1.2:1 for the last release (Table 8).

Returns of test fish to Lower Granite Dam during fall and spring were significantly different. The return of control fish during fall was significantly higher than test fish from each of the four release dates $(P<0.01, \mathrm{df}=1)$, which is reflected in low $\mathrm{T} / \mathrm{C}$ ratios ranging from $0.04: 1$ to $0.3: 1$. In contrast, spring returns show higher $T / C$ ratios for each release. Ratios ranged from 1.0:1 to $3.5: 1$, with the second and third groups showing significantly higher benefits of $1.9: 1$ and $3.5: 1$, respectively $(P<0.01, d f=1)$. Combined fall and spring recoveries at Lower Granite Dam show T/C ratios of 0.4:1 and 0.3:1 for the first release, $0.8: 1$ for the second release, 1.0:1 for the third release, and 0.2:1 for the fourth release (Table 8). Poorer survival of the control group probably accounted for the higher $\mathrm{T} / \mathrm{C}$ ratio for the third release group. The difference between recoveries in fall and spring at Lower Granite Dam was caused by a delay in migration of many test fish that overwintered in the Columbia River. Approximately $25 \%$ of the control fish were recovered in spring 1982 . In 1983, when only half as many control fish were transported around the dams, about $12 \%$ were recovered in spring. This suggests that transportation of juvenile steelhead from Dworshak NFH caused delay in migration of adults on their upstream migration. Our findings agree closely with those of Park (1985). In Park's analysis of steelhead returns following transportation at Little Goose and Lower Granite Dams, he observed that delays in the adult migration were likely attributable to Dworshak NFH fish in the transported populations. The cause of delay in upstream migration of transported Dworshak NFH steelhead is unclear, but it may relate to the relatively close proximity of the hatchery on the Clearwater River to downstream collection points. 
Adult recoveries in the fall Zone 6 Indian fishery were very similar to recoveries at Bonneville Dam (Tables 8 and 9). Control recoveries from the first release are slightly higher than recoveries from the corresponding test releases, with $\mathrm{T} / \mathrm{C}$ ratios of 0.8:1 for the first test and $0.8: 1$ for test T1A. However, test recoveries from the second and third releases were significantly higher than control recoveries $(P<0.01, d f=1$ ), and showed benefits of $1.8: 1$ and 1.9:1, respectively. The late release (Test T4) had the poorest return, and the $\mathrm{T} / \mathrm{C}$ ratio of $0.5: 1$ indicated significantly more controls returned. than did the test fish.

Recoveries in the winter Zone 6 fishery show that many test fish, but few control fish, overwintered in the lower Columbia River. Test to control ratios ranged from 5.4:1 to $18.3: 1$. In contrast, most of the control fish from each release seemed to have moved through the Columbia River during fall and overwintered in the Snake and Clearwater Rivers, and therefore were unavailable to the winter Indian fishery in the Columbia River. This was confirmed by the large numbers of control fish from each group that were recaptured in fall at Lower Granite Dam (Table 8) and in the sport fishery on the Snake and Clearwater Rivers (Table 10).

Recoveries in the sport fishery varied, but generally fewer test fish arrived at upstream locations. Recovery data are divided into the following areas: Columbia River below the Snake River, Columbia River above the Snake River, Snake River, and Clearwater River (Table 10). The recoveries were low on the Columbia River below the Snake River; test to control ratios ranged from 0.7:1 to 2.7:1. Only one fish was recovered in the Columbia River upstream from the mouth of the Snake River, indicating minimal straying.

The recoveries in the Snake and Clearwater Rivers were substantially higher than for the Columbia River, reflecting both the more intensive sport fishery and the proximity to the homing site. However, in most cases significantly more controls than test fish returned to the Snake River $(P<0.01$, $\mathrm{df}=1$ ), causing low $\mathrm{T} / \mathrm{C}$ ratios ranging 
Table 9.-Recoveries of adult steelhead in the fall and winter Zone 6 and Clearwater River Indian fisheries from juveniles released in spring 1982 from Dworshak National Fish Hatchery.

\begin{tabular}{|c|c|c|c|c|c|c|c|c|c|c|c|c|c|c|c|c|c|}
\hline \multirow[b]{3}{*}{ Treatment } & \multirow{3}{*}{$\begin{array}{l}\text { Date } \\
\text { juveniles } \\
\text { released }\end{array}$} & \multirow{3}{*}{$\begin{array}{l}\text { Number } \\
\text { juveniles } \\
\text { released }\end{array}$} & \multicolumn{3}{|c|}{ Fall Zone 6} & \multicolumn{3}{|c|}{ Winter Zone 6} & \multicolumn{3}{|c|}{ Ceremonial } & \multicolumn{3}{|c|}{ Clearwater $\mathrm{R}$. } & \multicolumn{3}{|c|}{ Total } \\
\hline & & & \multicolumn{2}{|c|}{ Total } & \multirow{2}{*}{$\begin{array}{l}\text { Test to } \\
\text { control } \\
\text { ratio }\end{array}$} & \multicolumn{2}{|c|}{ Total } & \multirow{2}{*}{$\begin{array}{l}\text { Test to } \\
\text { control } \\
\text { ratio }\end{array}$} & \multicolumn{2}{|c|}{ Total } & \multirow{2}{*}{$\begin{array}{l}\text { Test to } \\
\text { control } \\
\text { ratio }\end{array}$} & \multicolumn{2}{|c|}{ Total } & \multirow{2}{*}{$\begin{array}{l}\text { Test to } \\
\text { control } \\
\text { ratio }\end{array}$} & \multicolumn{2}{|c|}{ Total } & \multirow{2}{*}{$\begin{array}{l}\text { Test to } \\
\text { control } \\
\text { ratio }\end{array}$} \\
\hline & & & Number & Percent & & Number & Percent & & Number & Percent & & Number & Percent & & Nutnber & Percent & \\
\hline Control (C1) & 19 Apr & 29,838 & 138 & 0.46 & & 4 & 0.01 & & 1 & & & 14 & 0.05 & & 157 & 0.53 & \\
\hline Test (T1) & 19 Apr & 33,012 & 130 & 0.39 & $0.9:$ Ins & 23 & 0.07 & $5.4: 1-$ & 0 & & & 5 & 0.02 & $0.3: 1 \star$ & 158 & 0.48 & $0.9: \operatorname{lns}$ \\
\hline Test (TIA) & $19 \mathrm{Apr}$ & 32,185 & 125 & 0.39 & $0.8: 1 n s$ & 24 & 0.08 & $5.8: 1-$ & 3 & 0.01 & $3.10: 1$ & 5 & 0.02 & $0.3=1 *$ & 157 & 0.49 & $0.9: \ln s$ \\
\hline Control (C2) & $30 \mathrm{ApI}$ & 31,048 & 140 & 0.45 & & 10 & 0.03 & & 0 & & & 11 & 0.04 & & 161 & 0.52 & \\
\hline Test (T2) & 30 Apr & 32,911 & 268 & 0.81 & $1.8: 1 * \star$ & 94 & 0.26 & $8.0: 1 \star \star$ & 6 & 0.02 & & 10 & 0.03 & $0.8=105$ & 368 & 1.12 & $2.2: 1^{\star \star}$ \\
\hline Control (C3) & 19 May & 31,714 & 105 & 0.33 & & 4 & 0.01 & & 0 & & & 9 & 0.03 & & 118 & 0.37 & \\
\hline Test (T3) & 19 May & 29,456 & 184 & 0.63 & $1.9: 1 \star \star$ & 72 & 0.24 & $18.8: 1-$ & 9 & 0.03 & & 9 & 0.03 & $1.1:$ Ins & 274 & 0.93 & $2.5: 1 * *$ \\
\hline Test (T4) & 31 MaY & 31,915 & 54 & 0.17 & $0.5: 1^{* * *}$ & 14 & 0.04 & $3,4: 1^{2}--$ & $\underline{0}$ & & & $\underline{2}$ & 0.01 & $0.2: 1^{*}-$ & 70 & 0.219 & $0.59: 1^{4 \star \star}$ \\
\hline Totals & & 252,079 & 1,144 & & & 235 & & & 19 & & & 65 & & & 1,463 & & \\
\hline
\end{tabular}

- Since no control group was released with Test T4, it was compared to control C3 to obtain the test to control ratio.

$n s=$ Nonsignificant

$\star=$ Significant difference between the test and control groap (P $<0.05$, df $=1)$.

-- = Insufficient recoveries for statistical analysis. 
Table 10.--Recoveries of adult steelhead in the sport fishery in the Columbia, Snake, and Clearwater Rivers from juveniles released in spring 1982 from Dworshak National Fish Hatchery.

\begin{tabular}{|c|c|c|c|c|c|c|c|c|c|c|c|c|c|c|c|c|c|}
\hline \multirow[b]{3}{*}{ Treatment } & \multirow{3}{*}{$\begin{array}{l}\text { Date } \\
\text { juveniles } \\
\text { released }\end{array}$} & \multirow{3}{*}{$\begin{array}{l}\text { Number } \\
\text { juveniles } \\
\text { released }\end{array}$} & \multicolumn{3}{|c|}{$\begin{array}{c}\text { Columbia R. below } \\
\text { Snake R. }\end{array}$} & \multicolumn{3}{|c|}{$\begin{array}{c}\text { Columbia R. above } \\
\text { Snake R. }\end{array}$} & \multicolumn{3}{|c|}{ Snake R. } & \multicolumn{3}{|c|}{ Clearwater $\mathrm{R}$. } & \multicolumn{3}{|c|}{ Total } \\
\hline & & & \multicolumn{2}{|c|}{ Total } & \multirow{2}{*}{$\begin{array}{l}\text { Test to } \\
\text { control } \\
\text { ratio }\end{array}$} & \multicolumn{2}{|c|}{ Total } & \multirow{2}{*}{$\begin{array}{l}\text { Test to } \\
\text { control } \\
\text { ratio }\end{array}$} & \multicolumn{2}{|c|}{ TotaI } & \multirow{2}{*}{$\begin{array}{l}\text { Test to } \\
\text { control } \\
\text { ratio }\end{array}$} & \multicolumn{2}{|c|}{ Total } & \multirow{2}{*}{$\begin{array}{l}\text { Test to } \\
\text { control } \\
\text { ratio }\end{array}$} & \multicolumn{2}{|c|}{ Total } & \multirow{2}{*}{$\begin{array}{l}\text { Test to } \\
\text { control } \\
\text { ratio }\end{array}$} \\
\hline & & & Number & Percent & & Number & Percent & & Number & Percent & & Number & Percent & & Number & Percent & \\
\hline Control (C1) & 19 Apr & 29,838 & 8 & 0.03 & & 1 & 0.00 & & $4 I$ & 0.14 & & 67 & 0.23 & & 117 & 0.39 & \\
\hline Test (T1) & 19 Apr & 33,012 & 6 & 0.02 & $0.7:$ Ins & 0 & 0.00 & & 12 & 0.04 & $0.3=1 * t$ & 4 & 0.01 & $0.1: 1--$ & 22 & 0.07 & $0.2: 1 \star \star$ \\
\hline Test (TIA) & $19 \mathrm{Apr}$ & 32,185 & 9 & 0.03 & $1.0: 1 n s$ & 0 & 0.00 & & 8 & 0.03 & $0.2: 1 * \star$ & 9 & 0.03 & $0.1: 1 * \star$ & 26 & 0.08 & $0.2: 1 \star \star *$ \\
\hline Control (C2) & $30 \mathrm{Apr}$ & 31,048 & 6 & 0.02 & & 0 & 0.00 & & 60 & 0.19 & & 67 & 0.22 & & 133 & 0.43 & \\
\hline Test (T2) & $30 \mathrm{Apr}$ & 32.911 & 17 & 0.05 & $2.7: 1 \star$ & 0 & 0.00 & & 27 & 0.08 & $0.4: 1 * \star$ & 14 & 0.04 & $0.2: 1 * \star$ & 58 & 0.18 & $0.4: 1 * \star$ \\
\hline Control (C3) & 19 May & 31,714 & 4 & 0.01 & & 0 & 0.00 & & 20 & 0.06 & & 36 & 0.11 & & 60 & 0.19 & \\
\hline Test (x3) & 19 May & 29,456 & 9 & 0.03 & $2.4: 1--$ & 0 & 0.00 & & 11 & 0.04 & $0.6: 1 \mathrm{~ns}$ & 6 & 0.02 & $0.2=1 * \star$ & 26 & 0.09 & $0.5: 1 * \star$ \\
\hline Test (T4) & 31 May & 31,915 & 3 & 0.01 & $0.7: 1^{-}$ & $\underline{0}$ & 0.00 & & 7 & 0.02 & $0.4: 1^{4 \star}$ & 1 & 0.00 & & 11 & 0.03 & $0.2: 1^{* * *}$ \\
\hline Totals & & 252,079 & 62 & & & 1 & & & 186 & & & 204 & & & 453 & & \\
\hline
\end{tabular}

- Since no control group was released with Test-T4, it was corpared to Control c3 to obtain the test to control ratio.

ns = Nonsignificant.

* = Significant difference between the test and control group $(R<0.05, d f=1)$

$\star *$ = Significant difference between the test and control group $(\mathrm{P}<0.01, \mathrm{df}=1)$.

- = Insufficient recoveries for statistical analysis. 
from 0.2:1 to 0.6:1; even lower T/C ratios were observed on the Clearwater River (0.03:1 to $0.2: 1$ ). Many control fish arrived in the Snake and Clearwater Rivers during fall (fishing intensity and harvest is greatest during fall and winter), whereas most test fish arrived during spring the following year. Therefore, more fish from control groups were in the Snake and Clearwater Rivers for a longer period of time than test fish, making them more available to the sport fishery, and resulting in lower $\mathrm{T} / \mathrm{C}$ ratios.

Adult returns of test fish to the Dworshak NFH homing site were usually lower than returns from control releases (Table 11). Except for the third release (19 May), significantly more control fish were recovered from each release group $(P<0.01$, $\mathrm{df}=1$ ), resulting in low $\mathrm{T} / \mathrm{C}$ ratios of $0.6: 1$ and $0.5: 1$ for the first releases, $0.8: 1$ for the second release, and 1.4:1 for the third release. Because of the transportation program at the collector dams, the large number of controls that received the survival benefit similar to test fish, was probably a substantial factor in the low T/C ratios observed at the hatchery.

1983 releases--Recoveries of test fish at Bonneville Dam were substantially higher than controls, resulting in high T/C ratios for all releases (Table 12). Test to control ratios of 3.1:1 and 4.3:1 for the first releases (20 April), 5.9:1 for the second release (5 May), and 5.4:1 for the third release (24-25 May), demonstrate significant survival enhancement of fish transported from Dworshak NFH $(P<0.01, d f=1)$.

Recoveries at McNary Dam also showed high T/C ratios for the first release (7.9:1 and 8.3:1). No $\mathrm{T} / \mathrm{C}$ ratios are shown for the second and third releases because no controls were recaptured from those groups. Even so, test recoveries appeared favorable for the second release, although only four recoveries were recorded for the third release.

Test to control ratios of recoveries at Lower Granite Dam during spring were much higher than ratios during fall (Table 12). T/C ratios ranged from 1.3:1 to 1.8:1 
Table 11.--Returns of adult steelhead to the Dworshak National Fish Hatchery homing site from juveniles released there in spring 1982.

\begin{tabular}{|c|c|c|c|c|c|}
\hline \multirow[b]{2}{*}{ Treatment } & \multirow[b]{2}{*}{$\begin{array}{l}\text { Date } \\
\text { juveniles } \\
\text { released }\end{array}$} & \multirow[b]{2}{*}{$\begin{array}{l}\text { Number } \\
\text { juvenileg } \\
\text { released }\end{array}$} & \multicolumn{3}{|c|}{ Total adult recoveries } \\
\hline & & & Number & Percent & $\begin{array}{c}\text { Test to } \\
\text { control ratio }\end{array}$ \\
\hline Control (C1) & 19 Apr & 29,838 & 203 & 0.68 & \\
\hline Tegt (TI) & 19 Apr & 33,012 & 125 & 0.38 & $0.6: 1 * *$ \\
\hline Test (T1A) & 19 Apr & 32,185 & 107 & 0.33 & $0.5: 1 * *$ \\
\hline Control (C2) & 30 Apr & 31,048 & 255 & 0.82 & \\
\hline Test (T2) & 30 Apr & 32,911 & 208 & 0.63 & $0.8: 1 * *$ \\
\hline Control (C3) & $19 \mathrm{May}$ & 31,714 & 128 & 0.40 & \\
\hline Test (T3) & $19 \mathrm{May}$ & 29,456 & 170 & 0.58 & $1.4: 1 * \star$ \\
\hline$\cdot$ & & & . & & \\
\hline Test (T4) & 31 May & 31,915 & 43 & 0.14 & $0.3: 1^{\star * *}$ \\
\hline Total & & 252,079 & 1,239 & & \\
\hline
\end{tabular}

- Since no control group was released with Test (T4), it was compared to Control (C3) to obtain the test to control ratio.

** - Slgnificant difference between the test and control group $(P<0.01$, df -1$)$. 
Table 12.-Recoveries of adult steelhead at Bonneville, McNary, and Lower Granite Dams from juveniles released in spring 1983 from Dworshak National Fish Hatchery.

\begin{tabular}{|c|c|c|c|c|c|c|c|c|c|c|c|c|c|c|c|c|c|}
\hline \multirow[b]{3}{*}{ Treatment } & \multirow{3}{*}{$\begin{array}{l}\text { Date } \\
\text { juveniles } \\
\text { released }\end{array}$} & \multirow{3}{*}{$\begin{array}{l}\text { Number } \\
\text { juveniles } \\
\text { released }\end{array}$} & \multicolumn{3}{|c|}{ Bonneville Dam } & \multicolumn{3}{|c|}{ MCNacy Dam } & \multicolumn{9}{|c|}{ Lower Granite Dam } \\
\hline & & & \multicolumn{2}{|c|}{ Total } & \multirow{2}{*}{$\begin{array}{l}\text { Test to } \\
\text { control } \\
\text { ratio }\end{array}$} & \multicolumn{2}{|c|}{ Total } & \multirow{2}{*}{$\begin{array}{l}\text { Test to } \\
\text { control } \\
\text { ratio }\end{array}$} & \multicolumn{2}{|c|}{$\begin{array}{l}\text { Fall retw } \\
\text { gotal }\end{array}$} & \multirow{2}{*}{$\begin{array}{l}\text { ns } \\
\text { Test to } \\
\text { control } \\
\text { ratio }\end{array}$} & \multicolumn{2}{|c|}{$\begin{array}{l}\text { Spring ret } \\
\text { Iotal }\end{array}$} & \multirow{2}{*}{$\begin{array}{l}\text { irns } \\
\text { Test to } \\
\text { control } \\
\text { ratio }\end{array}$} & \multicolumn{2}{|c|}{$\begin{array}{l}\text { Total ret } \\
\text { Total }\end{array}$} & \multirow{2}{*}{$\begin{array}{l}\text { urns } \\
\text { Test to } \\
\text { control } \\
\text { ratio }\end{array}$} \\
\hline & & & Number & Percent & & Number & Percent & & Number & Percent & & Number & Percent & & Number & Percent & \\
\hline Control (C1) & $20 \mathrm{ApI}$ & 33,178 & 43 & 0.13 & & 7 & 0.02 & & 195 & 0.59 & & 18 & 0.05 & & 213 & 0.64 & \\
\hline Test (T1) & $20 \mathrm{Apr}$ & 30,341 & 123 & 0.41 & $3.1: 1 * \star$ & 50 & 0.17 & $7.9: 1 * \star$ & 234 & 0.77 & $1.3: 1 * \star$ & 183 & 0.60 & $11.2: 1 * \star$ & 417 & 1.37 & $2.1: 1 \star \star$ \\
\hline Test. (TIA) & 20 Ap $x$ & 28,658 & 161 & 0.56 & $4.3: 1 * \star$ & 50 & 0.17 & $8.3: 1 * \star$ & 230 & 0.80 & $1.4: 1 * *$ & 195 & 0.68 & $12.6: 1 * \star$ & 425 & 1.48 & $2.3: 1 * *$ \\
\hline Control (C2) & 5 May & 32,236 & 23 & 0.07 & & 0 & 0.00 & & 162 & 0.50 & & 29 & 0.09 & & 191 & 0.59 & \\
\hline Control (C2A) & 5 May & 31,956 & 31 & 0.10 & & 1 & 0.00 & & 162 & 0.51 & & 26 & 0.08 & & 188 & 0.59 & \\
\hline Test (T2) & 5 May & 32,465 & 136 & 0.42 & $5.9: 1 * *$ & 42 & 0.13 & & 259 & 0.80 & $1.6: 1 \star \star$ & 188 & 0.58 & $6.4=1 * \star$ & 447 & 1.38 & $2.3: 1 * *$ \\
\hline Control (C3) & 25 May & 30,751 & 2 & 0.01 & & 0 & 0.00 & & 17 & 0.06 & & 1 & 0.00 & & 18 & 0.06 & \\
\hline Test (T3) & 24 May & 31,906 & 12 & 0.04 & $5.4: 1-$ & 4 & 0.01 & & 32 & 0.10 & $1.8: 1 *$ & 13 & 0.04 & $13.7: 1 * \star$ & 45 & 0.14 & $2.4: 1 * \star$ \\
\hline Totals & & 251,491 & 531 & & & 154 & & & 1,291 & & & 653 & & & 1,944 & & \\
\hline
\end{tabular}

* = Significant difference between the test and control group $(\mathrm{P}<0.05$, df $=1$ ).

* = Significant difference between the test and control group $(\mathrm{P}<0.01$, df $=1)$ 
for fall recoveries. As with 1982 recoveries, much higher $\mathrm{T} / \mathrm{C}$ ratios (ranging from 6.4:1 to 13.7:1) were recorded in spring, indicating that many test fish arrived somewhat later than control fish to Lower Granite Dam because of a delay in migration. When fall and spring recoveries were combined, all three releases showed significantly higher recoveries from the test groups than from control groups $(P<0.01, d f=1)$. Test to control ratios were 2.1:1 and 2.3:1 for the first releases, 2.3:1 for the second release, and 2.4:1 for the third release.

All T/C ratios except Test $\mathrm{T} 2$ and T3 at McNary Dam indicated treatment benefits at each of the in-river sampling sites. High T/C ratios at lower-river sampling sites (Bonneville and McNary Dams) coupled with lower ratios during fall and higher ratios during spring at Lower Granite Dam indicate some homing impairment, although much less than in the 1982 groups. In contrast to 1982, all T/C ratios indicated benefits of barge treatment as far upstream as Lower Granite Dam.

Recoveries in the fall and winter Zone 6 Indian fishery exhibited a sharp contrast to recoveries in this fishery from 1982 releases. Test to control ratios in the fall Zone 6 Indian fishery from 1983 releases were similar to those observed at Bonneville Dam (3.5:1 and 4.4:1 for the first releases, 5.2:1 for the second release, and 4.7:1 for the third release) (Table 13). In the winter Zone 6 Indian fishery, only 61 fish were recovered from releases in 1983 compared to 235 fish from the 1982 releases. In contrast to 1982 when many fish overwintered in the Columbia River, fish from the 1983 releases migrated upstream with minimal delay and overwintered in the Snake and Clearwater Rivers.

Nez Perce Tribal fisherman harvested 166 jaw-tagged steelhead that were released in 1983 from the Clearwater River (Table 13). Test to control ratios were 3.1:1 for the first releases and 5.0:1 for the second release. Only one test fish was recovered from the third release. 
Table 13.-Recoveries of adult steelhead in the fall and winter Zone 6, ceremonial, and Clearwater River Indian fisheries from juveniles released in spring 1983 from Dworshak National Fish Hatchery.

\begin{tabular}{|c|c|c|c|c|c|c|c|c|c|c|c|c|c|c|c|c|c|}
\hline \multirow[b]{3}{*}{ Treatment } & \multirow{3}{*}{$\begin{array}{l}\text { Date } \\
\text { juveniles } \\
\text { released }\end{array}$} & \multirow{3}{*}{$\begin{array}{l}\text { Number } \\
\text { juveniles } \\
\text { released }\end{array}$} & \multicolumn{3}{|c|}{ Fall zone 6} & \multicolumn{3}{|c|}{ Finter Zone 6} & \multicolumn{3}{|c|}{ Ceremonial } & \multicolumn{3}{|c|}{ Clearwater R. } & \multicolumn{3}{|c|}{ Total } \\
\hline & & & \multicolumn{2}{|c|}{ Totai } & \multirow{2}{*}{$\begin{array}{l}\text { Test to } \\
\text { control } \\
\text { Iatio }\end{array}$} & \multicolumn{2}{|c|}{ Total } & \multirow{2}{*}{$\begin{array}{l}\text { Test to } \\
\text { control } \\
\text { ratio }\end{array}$} & \multicolumn{2}{|c|}{ Total } & \multirow{2}{*}{$\begin{array}{l}\text { Test to } \\
\text { control } \\
\text { ratio }\end{array}$} & \multicolumn{2}{|c|}{ Total } & \multirow{2}{*}{$\begin{array}{l}\text { Test to } \\
\text { contxol } \\
\text { ratio }\end{array}$} & \multicolumn{2}{|c|}{ Total } & \multirow{2}{*}{$\begin{array}{l}\text { Test to } \\
\text { control } \\
\text { ratio }\end{array}$} \\
\hline & & & Number & Percent & & Number & Percent & & Number & Percent & & Number & Percent & & Number & Percent & \\
\hline Control (C1) & $20 \mathrm{API}$ & 33,178 & 48 & 0.14 & & 0 & & & 0 & & & 16 & 0.05 & & 64 & 0.19 & \\
\hline Test (T1) & $20 \mathrm{Apr}$ & 30,341 & 151 & 0.50 & $3.5: 1^{\star \star}$ & 12 & 0.04 & & 0 & & & 45 & 0.15 & $3.1: 1 \star \star$ & 208 & 0.69 & $3.6: 1^{* \star}$ \\
\hline Test (T1A) & $20 \mathrm{API}$ & 28,658 & 182 & 0.64 & $4.4: 1 \star \star$ & 16 & 0.06 & & 1 & 0.00 & & 42 & 0.15 & $3.1: 1 \star \star \star$ & 241 & 0.84 & $4.4: 1 \pm \star \star$ \\
\hline Control (C2) & 3 May & 32,236 & 34 & 0.11 & & 1 & 0.00 & & 0 & & & 8 & 0.03 & & 43 & 0.13 & \\
\hline Control (C2A) & 3 May & 31,956 & 61 & 0.19 & & 2 & 0.01 & & 0 & & & 13 & 0.04 & & 76 & 0.24 & \\
\hline Test (T2) & 3 May & 32,465 & 176 & 0.54 & $5.2: 1 \star \star$ & 27 & 0.08 & $27.7: 1--$ & 0 & & & 41 & 0.13 & $5.4: 1 * \star$ & 244 & 0.75 & $5.7: 1 * \star$ \\
\hline Control (C3) & 25 May & 30,751 & 3 & 0.01 & & 0 & & & 0 & & & 0 & & & 3 & 0.01 & \\
\hline Test (T3) & 24 May & 31,906 & 15 & 0.05 & $4.7: 1--$ & $\underline{3}$ & 0.01 & & $\underline{0}$ & & & 1 & 0.00 & & 19 & 0.06 & $6.0: 1--$ \\
\hline Totals & & 251,491 & 670 & & & 61 & & & 1 & & & 166 & & & 898 & & \\
\hline
\end{tabular}

$\star \star=$ Significant difference between the test and control group $(P<0.01$, df $=1$ ).

-- Insufficient recoveries for statistical analysis. 
Recoveries in the sport fishery suggested a delay in migration of test fish, resulting in lower $\mathrm{T} / \mathrm{C}$ ratios at upstream sampling points. Of the 403 fish total, 198 were recovered in the Clearwater River, 140 in the Snake River, and 65 in the Columbia River downstream from its confluence with the Snake River (Table 14). No fish were recovered from the Columbia River above the Snake River, indicating no straying to the upper Columbia River. Test to control ratios from the Columbia River below the Snake River ranged from 4.4:1 to $11.8: 1$ for the first two releases. No recoveries were made from the third release. Test to control ratios were lower in the Snake River, ranging from $1.6: 1$ to $1.8: 1$. Further reduced T/C ratios were observed upstream in the Clearwater River. Test to control ratios ranged from 1.0:1 to 1.3:1 for the first two releases, whereas the third release showed a $\mathrm{T} / \mathrm{C}$ ratio of $0.3: 1$, with only nine fish recaptured.

Test to control ratios to Dworshak NFH were 2.0:1 and 2.1:1 for the first releases, 1.9:1 for the second release, and 2.9:1 for the third release (Table 15). These are comparable to $\mathrm{T} / \mathrm{C}$ ratios at Lower Granite Dam, indicating minimal homing impairment for fish recovered between these sites. These ratios are very encouraging-showing a significantly higher return of test fish than control fish in each release group $(\mathrm{P}<0.01, \mathrm{df}=1)$.

Returns to the Dworshak NFH homing site showed a substantial benefit from barge treatment and $\mathrm{T} / \mathrm{C}$ ratios were consistent, suggesting that twice as many adults may return to the homing site than would be expected if they were released at the hatchery, if juveniles are transported in years such as 1983 when inriver survival was relatively low.

The higher T/C ratios from the 1983 releases to all recovery sites indicate that these fish had a higher survival benefit from transportation from Dworshak NFH than did those from the 1982 release. In fact, while not measurable, benefits may have been 
Table 14.--Recoveries of adult steelhead in the sport fishery in the Columbia, Snake, and Clearwater Rivers from juveniles released in spring 1983 from Dworshak National Fish Hatchery.

\begin{tabular}{|c|c|c|c|c|c|c|c|c|c|c|c|c|c|c|c|c|c|}
\hline \multirow[b]{3}{*}{ Treatment } & \multirow{3}{*}{$\begin{array}{l}\text { Date } \\
\text { juveniles } \\
\text { released }\end{array}$} & \multirow{3}{*}{$\begin{array}{l}\text { Number } \\
\text { juveniles } \\
\text { released }\end{array}$} & \multicolumn{3}{|c|}{$\begin{array}{c}\text { Columbia R. below } \\
\text { Snake R. }\end{array}$} & \multicolumn{3}{|c|}{$\begin{array}{c}\text { Columbia R. above } \\
\text { Snake R. }\end{array}$} & \multicolumn{3}{|c|}{ Snake R. } & \multicolumn{3}{|c|}{ Clearrater R. } & \multicolumn{3}{|c|}{ Total } \\
\hline & & & \multicolumn{2}{|c|}{ Total } & \multirow{2}{*}{$\begin{array}{l}\text { Test to } \\
\text { control } \\
\text { ratio }\end{array}$} & \multicolumn{2}{|c|}{ Total } & \multirow{2}{*}{$\begin{array}{l}\text { Test to } \\
\text { control } \\
\text { ratio }\end{array}$} & \multicolumn{2}{|c|}{$\frac{\text { Snake K }}{\text { Total }}$} & \multirow{2}{*}{$\begin{array}{l}\text { Test to } \\
\text { control } \\
\text { ratio }\end{array}$} & \multicolumn{2}{|c|}{$\begin{array}{l}\text { Clearkacer } \\
\text { Total } \\
\end{array}$} & \multirow{2}{*}{$\begin{array}{l}\text { Test to } \\
\text { control } \\
\text { ratio }\end{array}$} & \multicolumn{2}{|c|}{ Total } & \multirow{2}{*}{$\begin{array}{l}\text { Test to } \\
\text { control } \\
\text { ratio }\end{array}$} \\
\hline & & & Number & Percent & & Number & Percent & & Number & Percent & & Number & Percent & & Number & Percent & \\
\hline Control (C1) & $20 \mathrm{ApI}$ & 33,178 & 3 & 0.01 & & & 0 & & 21 & 0.06 & & 34 & 0.10 & & 58 & 0.18 & \\
\hline Test (TI) & 20 Apr & 30,341 & 12 & 0.04 & $4.4: 1-$ & & 0 & & 30 & 0.10 & $1.6=1 \mathrm{~ns}$ & 41 & 0.14 & $1.3=\ln 3$ & 83 & 0.27 & $1.6: 1 *$ \\
\hline Test (TIA) & $20 \mathrm{Apr}$ & 28,658 & 21 & 0.07 & $8.1: 1-$ & & 0 & & 33 & 0.12 & $1.8: 1 \mathrm{~ns}$ & 28 & 0.10 & $1.0: 1 \mathrm{~ns}$ & 82 & 0.29 & $1.6: 1^{\star \star}$ \\
\hline Control (C2) & 3 May & 32,236 & 2 & 0.01 & & & 0 & & 12 & 0.04 & & 28 & 0.09 & & 42 & 0.13 & \\
\hline Control (C2A) & 3 May & 31,956 & 4 & 0.01 & & & 0 & & 21 & 0.07 & & 29 & 0.09 & & 54 & 0.17 & \\
\hline Test (T2) & 3 May & 32,465 & 23 & 0.07 & $11.8: 1-$ & & 0 & & 21 & 0.07 & $1.8=1 \mathrm{~ns}$ & 29 & 0.09 & $1.0: 1 \mathrm{~ns}$ & 73 & 0.23 & $1.7=1 * \star$ \\
\hline Control (C3) & 25 May & 30,751 & 0 & & & & 0 & & 0 & 0.00 & & 7 & 0.02 & & 7 & 0.02 & \\
\hline Test (T3) & 24 May & 31,906 & $\underline{0}$ & & & & $\underline{0}$ & & $\underline{2}$ & 0.01 & & $\underline{2}$ & 0.01 & $0.3: 1--$ & 4 & 0.01 & $0.6=1-1$ \\
\hline Totals & & 251,491 & 65 & & & & 0 & & 140 & & & 198 & & & 403 & & \\
\hline
\end{tabular}

\footnotetext{
ns $=$ Nonsignificant.

$*$ = Significant difference between the test and control group $(P<0.05$, df $=1$ )

$\star \star=$ Significant difference between the test and control group $(P<0.01$, df $=1)$.

$--=$ Insufficient recoveries for statistical analysis.
} 
Table 15.--Returns of adult steelhead to the Dworshak National Fish Hatchery homing site from juveniles released there in spring 1983.

\begin{tabular}{|c|c|c|c|c|c|}
\hline \multirow[b]{2}{*}{ Treatment } & \multirow[b]{2}{*}{$\begin{array}{l}\text { Date } \\
\text { juveniles } \\
\text { released }\end{array}$} & \multirow[b]{2}{*}{$\begin{array}{l}\text { Number } \\
\text { juveniles } \\
\text { released }\end{array}$} & \multicolumn{3}{|c|}{ Total adult recoveries } \\
\hline & & & Number & Percent & $\begin{array}{l}\text { Test to } \\
\text { control } \\
\text { ratio }\end{array}$ \\
\hline Control. (C1) & 20 Apr & 33,178 & 95 & 0.29 & \\
\hline Test (T1) & 20 Apr & 30,341 & 170 & 0.56 & $2.0: 1 * *$ \\
\hline Tegt (TIA) & $20 \mathrm{Apr}$ & 28,658 & 171 & 0.60 & $2.1: 1 * *$ \\
\hline Control (C2) & 3 May & 32,236 & 90 & 0.28 & \\
\hline Control (C2A) & 3 May & 31,956 & 97 & 0.30 & \\
\hline Test (T2) & 3 May & 32,465 & 173 & 0.53 & $1.9: 1 * *$ \\
\hline Control (C3) & 25 May & 30,751 & 7 & 0.02 & \\
\hline Test (T3) & 24 May & 31,906 & 21 & 0.07 & $2.9: 1 * *$ \\
\hline Total & & 251,491 & 812 & & \\
\hline
\end{tabular}


similar between the two years if the downstream treatment of controls during the two years had been constant.

Each year, two test groups (T1 and T1A) were evaluated during the first release. As previously mentioned, T1A was pumped to an alternate pond to duplicate the successful test treatment used by Slatick et al. (1982). Adult returns from both release years indicate no difference between the test treatments. Therefore, holding fish in an alternate pond appears unnecessary for imprinting Dworshak NFH steelhead.

\section{Ocean Recoveries}

Five marked Dworshak NFH steelhead were recovered by the foreign high seas fishery in the western North Pacific Ocean (Fig. 3). Four of the fish were from 1982 and 1983 test groups while one control was recovered from a 1982 release. The farthest western recovery was at lat. $42^{\circ} \mathrm{N}$, long. $167^{\circ} \mathrm{E}$ on $1 \mathrm{July}$ 1983. These fish were recovered between 1 July and 3 August after spending 14 to 15 months at sea. These high-sea recoveries support Okazaki's (1986) hypothesis that the inland steelhead populations of North America exhibit remarkable westward extensions which reach as far as long. $160^{\circ} \mathrm{E}$ in summer. Okazaki defines the inland group as being from the Fraser and Columbia River drainages east of the Cascade Mountains. 


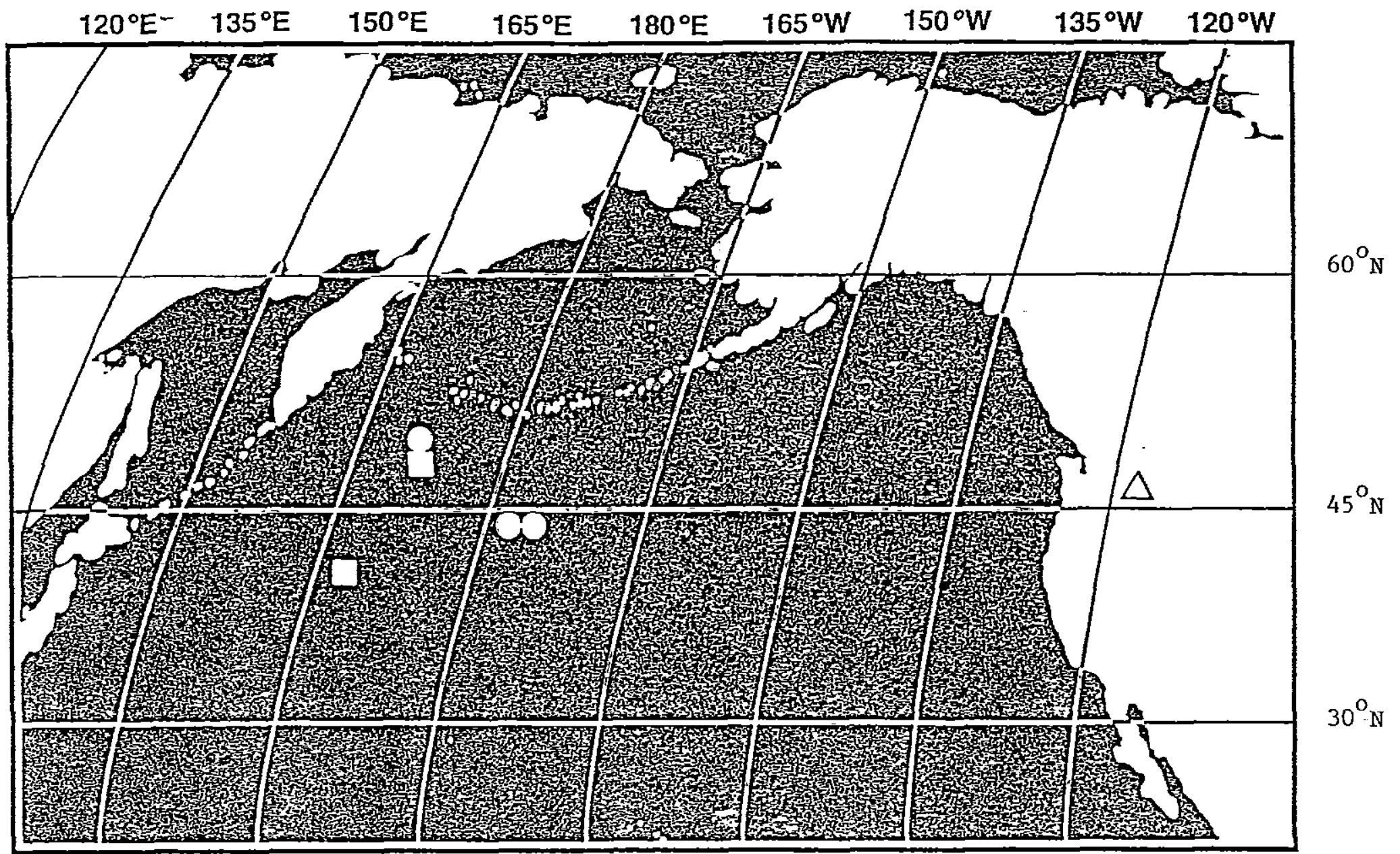

Figure 3.--Distribution of ocean recoveries of coded-wire-tagged steelhead from homing

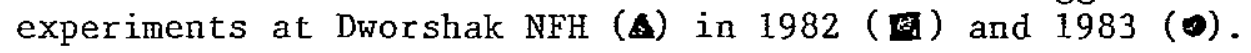




\section{SUMMARY AND CONCLUSIONS}

1. Eight groups of approximately 30,000 juvenile steelhead each were marked in both 1982 and 1983 (500,000 total) at Dworshak NFH. Fish were marked with coded wire tags, excised adipose fins, and brands and either released as smolts from the Dworshak NFH homing site or trucked to a barge at Lewiston, Idaho, and then barged and released below Bonneville Dam on the Columbia River. Smolts were monitored at Little Goose, McNary, and John Day Dams on the Snake and Columbia Rivers and in the estuary. Adults were subsequently recovered at Lower Granite, McNary, and Bonneville Dams, in the Indian (Zone 6 and Clearwater River) and sport fisheries, and at Dworshak NFH.

2. Fish were examined before release to define general health and the degree of smoltification. In both years fish appeared to be in good health and $\mathrm{Na}^{+}-\mathrm{K}^{+}$ATPase activity was within the range expected.

3. Smolts monitored at dams and in the estuary provided data on downstream migration. Many control fish released directly from Dworshak NFH in 1982 and 1983 received the benefit of transportation from the collector dams (57 and 29\%, respectively).

4. Survival of control groups released in April 1982 was excellent to all recovery sites. The adult recovery was approximately $1.6 \%$ at Lower Granite Dam and a record high $0.8 \%$ at Dworshak NFH. (The return of about $0.3 \%$ from 1983 releases of control fish represents a more normal return rate when compared to past hatchery records). The unusually high survival from 1982 releases was probably a combination of high smolt survival to the collector dams, an added benefit from $57 \%$ of the control fish being transported from the collector dams to below Bonneville Dam, and excellent ocean survival. Little survival enhancement was noted, probably because of the abnormally high recoveries of control fish. 
5. Many adults from test releases in $\mathbf{1 9 8 2}$ exhibited a delay in upstream migration to the Snake and Clearwater Rivers in fall.

6. There was a significant benefit from transporting fish from the hatchery in $\mathbf{1 9 8 3}$ as indicated by the high $T / C$ ratios at most major sampling sites. Homing was less impaired from 1983 releases as indicated by higher $\mathrm{T} / \mathrm{C}$ ratios at the hatchery and fewer fish (especially test fish) taken in the Zone 6 winter Indian fishery than from the 1982 release.

7. Dworshak NFH steelhead returns were highest when fish were released in late April or early May; barging during that period has the potential for substantially increasing returns of Dworshak NFH steelhead to all recovery sites.

8. There were five recoveries in July and August in the western North Pacific Ocean. These fish had spent 14 to 15 months at sea.

\section{ACKNOWLEDGMENTS}

Support for this research came from the Pacific Northwest's electrical ratepayers through the Bonneville Power Administration. The U.S. Army Corps of Engineers provided the fish barges for transporting smolts, and supported adult collection facilities at dams on the Columbia and Snake Rivers. The U.S. Fish and Wildlife Service at Dworshak National Fish Hatchery assisted in the marking and transportation of smolts as well as in the recovery of adults. Assistance in adult recoveries was also provided by the Oregon Department of Fish and Wildlife, Washington Department of Wildlife, and the Idaho Department of Fish and Game. 


\section{LITERATURE CITED}

Basham, L. R., M. R. Delarm, S. W. Petit, J. B. Athearn, and J. V. Barker.

1983. Fish transportation oversight team annual report - FY1982́ transport operations on the Snake and Columbia Rivers. NOAA Technical Memorandum, NMFS F/NWR5, 74 p. plus Appendix.

Bishop, Y. M. M., S. E. Fienberg, and P. W. Holland.

1975. Discrete multivariate analysis. The MIT Press, Cambridge, Mass. 557 p.

Dawley, E. M., R. D. Ledgerwood, T. H. Blahm, R. A. Kirn, and A. E. Rankin.

1983. Migrational characteristics and survival of juvenile salmonids entering the Columbia River estuary in 1982. Report to the Bonneville Power Administration, Contract DE-A179-82-BP30578, 49 p. plus Appendix. Available from Northwest Fisheries Center, 2725 Montlake Blvd. E., Seattle, WA 98112-2097.

Dawley, E. M., R. D. Ledgerwood, T. H. Blahm, R. A. Kirn, and A. E. Rankin. 1984. Migrational characteristics and survival of juvenile salmonids entering the Columbia River estuary in 1983. Report to the Bonneville Power Administration, Contract DE-A179-82-BP30578, 88 p. plus Appendix. Northwest Fisheries Center, 2725 Montlake Blvd. E., Seattle, WA 98112-2097.

Durkin, J. T., W. J. Ebel, and J. R. Smith.

1969. A device to detect magnetized wire tags in migrating adult coho salmon. J. Fish. Res. Board Can. 26:3083-3088.

Ebel, W. J.

1974. Marking fishes and invertebrates. III. Coded wire tag useful in automatic recovery of chinook salmon and steelhead trout. Mar. Fish. Rev. 36(7):10-13.

Gilbreath, L. G., L. R. Basham, and E. Slatick.

1976. Distribution, age, and size of tagged adult steelhead trout in the Snake River drainage. Mar. Fish. Rev. 39(6):14-18.

Harmon, J. R., and E. Slatick.

1983. Use of a fish transportation barge for increasing returns of steelhead imprinted for homing. Report to Bonneville Power Administration, Contract DE-A179-83-BP39643, 13 p. plus Appendix. Northwest Fisheries Center, 2725 Montlake Blvd. E., Seattle, WA 98112-2097.

Harmon, J. R., and E. Slatick.

1984. Use of a fish transportation barge for increasing returns of steelhead imprinted for homing. Report to Bonneville Power Administration, Contract DE-A179-83-BP39643, 17 p. plus Appendix. Northwest Fisheries Center, 2725 Montlake Blvd. E., Seattle, WA 98112-2097.

Okazaki, T.

1986. Studies of closely related species Salmo gairdneri and Salmo mykiss; their distribution and migration in the North Pacific and systematics. Far Seas Fish. Res. Lab, Shimizu, Japan, Bull. 23:1-66. 
Park, D. L.

1985. A review of smolt transportation to bypass dams on the Snake and

Columbia Rivers. Part II of comprehensive report of juvenile salmonid

transportation. U.S. Army Corps of Engineers, Walla Walla District, Walla Walla, WA, p. 2-1 to 2-65.

Sims, C. W., R. C. Johnsen, D. A. Brege, and A. Giorgi.

1983. Migrational characteristics of juvenile salmon and steelhead trout in the Columbia River system, 1982. Report to the U.S. Army Corps of Engineers, Contract DAC57-80-F0394, 35 p. plus Appendix. Northwest Fisheries Center, 2725 Montlake Blvd. E., Seattle, WA 98112-2097.

Slatick, E.

1976. Comparative retention of dart and jaw tags on chinook salmon and steelhead trout tagged on their spawning migration. Mar. Fish. Rev. 38(7):24-26.

Slatick, E., L. G. Gilbreath, J. R. Harmon, and K. A. Walch.

1982. Imprinting salmon and steelhead trout for homing, 1981. Report to the Bonneville Power Administration, Contract DE-A179-81-BP-BP27981, 52 p. plus Appendix. Northwest Fisheries Center, 2725 Montlake Blvd. E., Seattle, WA 98112-2097.

Sokal, R. R., and F. J. Rohlf.

1981. Biometry. W. H. Freeman, San Francisco, California. 859 p. 
APPENDIX 1

Data Summaries 
Appendix Table 1-1.--Summary of adult steelhead marked as juveniles at Dworshak National Fish Hatchery in 1982 .

1982 DWORSHAK - CONTROL (C1)

STEELHEAD

Release date: 4-19-82

Number juyeniles released: 29,838

Marks used - Brand: LAK-3 CWT: 23-6-6

Recovery Area

Adult Trapping Facilities

Bonneville

McNary

Lower Granite

River Sport

Columbia $R$. below Snake $R$.

Columbia R. above Snake R.

Snake R.

Clearwater $R$.

Indian Fishery

Fall Zone 6

138

Winter Zone 6

Clearwater

Ceremonial

Dworshak Hatchery

Other Hatcheries

Stream Survey

Ocean Fishery

4

14

1

203

0

3
No. of Returns Percent Return

171

0.573

20

0.067

489

1.639

8

0.027

1

0.003

41

0.137

67

0.225

0.462

0.013

0.047

0.003

0.680

0.0

0.010

Totals $\frac{1}{1,161}$

$\frac{0.003}{3.891}$ 
Appendix Table 1-2.--Summary of adult steelhead marked as juveniles at Dworshak National Fish Hatchery in 1982 .

\section{DWORSHAK - TEST (T1)}

STEELHEAD

Release date: 4-19-82

Number juveniles released: $33,0.12$

Marks used - Brand: RAL-4 CWT: 23-6-8

Recovery Area

Adult Trapping Facilities

Bonnevilie

McNary

Lower Granite

River Sport

Columbia $R$. below Snake R.

Columbia R. above Snatre R.

Snake $\mathbb{R}$.

Clearwater R.

Indian Fishery

Fal1 Zone 6

130

Winter Zone 6

Clearwater

Ceremonial

Dworshak Hatchery

Other Hatcheries

Stream Survey

Ocean Fishery
146

54

208

0

12

4

0.442
0.164
0.630

0.018

0.0

0.036

0.012

No of Returns Percent Return

$\begin{array}{cl}23 & 0.070 \\ 5 & 0.015 \\ 0 & 0.0\end{array}$

$\begin{array}{rrl}125 & 0.379 \\ 0 & 0.0 \\ 1 & 0.003 \\ \text { Totals } \quad \frac{0}{714} & \frac{0.0}{2.163}\end{array}$


Appendix Table 1-3.--Summary of adult steelhead marked as juveniles at Dworshak National Fish Hatchery in 1982 .

\section{DWORSHAK - TEST (TIA)}

STEELHEAD

Release date: 4-19-82

Number juveniles released: 32,185

Marks used - Brand: RAL-3 CWT: 23-6-7

Recovery Area

Adult Trapping Facilities

Bonnevilie

MoNary

Lower Granite
122

0.379

24

147
Percent Return

River Sport

Columbia R. below Snake R.

0.028

Columbia R. above Snake R.

0.0

Snake $R$.

8

0.025

Clearwater R.

9

0.028

Indian Fishery

Fall Zone 6

125

0.388

Winter Zone 6

24

0.075

Clearwater

5

0.016

Ceremonial

3

0.009

Dworshak Hatchery

107

0.332

Other Hatcheries

2

0.006

Stream Survey

2

0.006

Ocean Fishery

Totals $\frac{0}{587}$

$\frac{0.0}{1.824}$ 
Appendix Table 1-4.--Summary of adult steelhead marked as juveniles at Dworshak National Fish Hatchery in 1982 .

1982 DWORSHAK - CONTROL (C2)

STEELHEAD

Release date: $\quad 4-30-82$

Number juveniles released: 31,048

Marks used - Brand: LAK-2 CWT: 23-16-4

\section{Recovery Area}

No. of Returns Percent Return

Adult Trapping Facilities

Bonneville

220

0.709

MoNary

10

0.032

Lower Granite

500

1.610

River Sport

Columbia R. below Snake R.

6

0.019

Columbia $R$. above Snake $R$.

0

0.0

Snake R.

60

0.193

Clearwater $R$.

67

0.216

Indian Fishery

Fall Zone 6

140

0.451

Winter Zone 6

10

0.032

Clearwater

11

0.035

Ceremonial

$$
0
$$

0.0

Dworshak Hatchery

255

0.821

Other Hatcheries

1

0.003

Stream Survey

0

0.0

Ocean Fishery

Totals $\frac{0}{1,280}$

$\frac{0.0}{4.123}$ 
Appendix Table 1-5.--Summary of adult steelhead marked as juveniles at Dworshak National Fish Hatchery in 1982 .

\section{DWORSHAK - TEST (T2)}

STEELEEAD

Release date: 4-30-82

Number juveniles released: 32,911

Marks used - Brand: RAL-2 CWT: 23-16-5

Recovery Area

Adult Trapping Facilities

Bonneville

McNary

Lower Granite

River Sport

Columbia $R$. below Snake $R$.

Columbia R. above Snake R.

Snake R.

Clearwater $R$.

Indian Fishery

Fall Zone 6

268

Winter Zone 6

Clearwater

Ceremonial

Dworshak Hatchery

Other Hatcheries

Stream Survey

Ocean Fishery

0

27

14
322

0.978

48

0.146

413

1.255

Percent Return

0.052

0.0

0.082

0.043

\begin{tabular}{|c|c|c|}
\hline & 268 & 0.814 \\
\hline & 84 & 0.255 \\
\hline & 10 & 0.030 \\
\hline & 6 & 0.018 \\
\hline & 208 & 0.632 \\
\hline & 1 & 0.003 \\
\hline & 2 & 0.006 \\
\hline & 0 & 0.0 \\
\hline Totals & 1,420 & 4.315 \\
\hline
\end{tabular}


Appendix Table 1-6.--Summary of adult steelhead marked as juveniles at Dworshak National Fish Hatchery in 1982 .

1982 DWORSHAK - CONTROL (C3)

STEELHEAD

Release date: 5-19-82

Number juveniles released: $\quad 31,714$

Marks used - Brand: LAK-1 CWT: 23-16-2

Recovery Area

No. of Returns Percent Return

Adult Trapping Facilities

Bonneville

McNary

Lower Granite

River Sport

Columbia R. below Snake R.

Columbia R. above Snake R.

Snake R.

Clearwater $\mathrm{R}$.

Indian Fishery

Fall Zone 6

Winter Zone 6

Clearwater

Ceremonial

Dworshak Hatchery

Other Hatcheries

Stream Survey

Ocean Fishery
133

0.419

14

330

0.044

1.041

0.013

0

0.0

20

0.063

36

0.114

105

0.331

4

0.013

9

0.028

0

0.0

128

0.404

0

0.0

0

0.0

Totals

$\frac{0}{783}$

$\frac{0,0}{2.469}$ 

Appendix Table 1-7.--Summary of adult steelhead marked as juveniles at Dworshak National Fish Hatchery in 1982 .
1982 DWORSHAK - TEST (T3)
STEELHEAD

Release date: 5-19-82

Number juveniles released: 29,456

Marks used - Brand: RA) $(-1$ CWT: 23-16-3

Recovery Area

Adult Trapping Facilities

Bonnevilie

MoNary

Lower Granite
37

290

No. of Returns Percent Return

\section{River Sport}

Columbia $R$. below Snake $R$.

0.031

Columbia R. above Snake R.

0

0.0

Snake R.

11

0.037

Clearwater R.

0.020

Indian Fishexy

Fall Zone 6

Winter Zone 6

Clearwater

Ceremonial

Dworshak Hatchery

Other Hatcheries

Stream Survey

Ocean Fishery

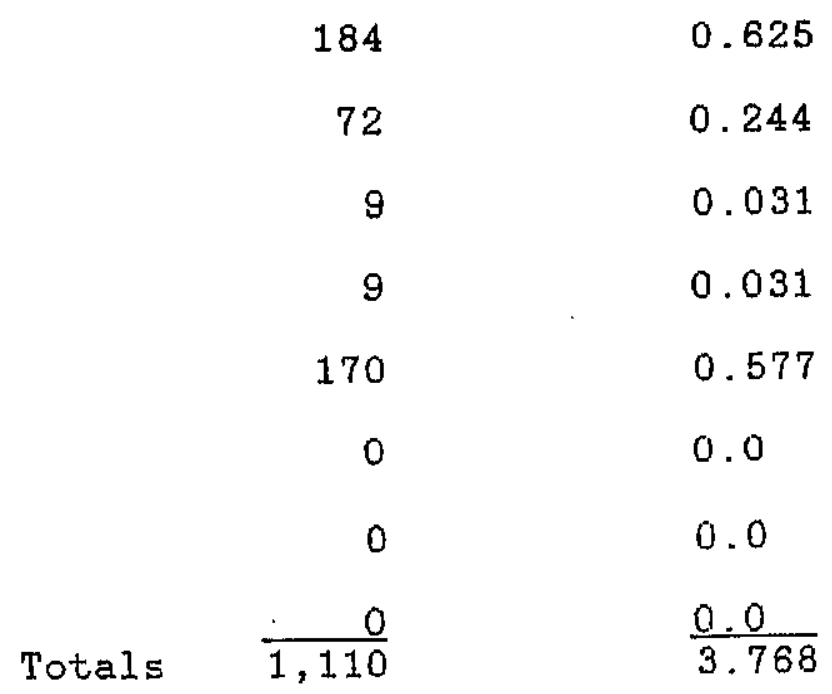


Appendix Table 1-8.--Summary of adult steelhead marked as juveniles at Dworshak National $\mathrm{Fish}$ Hatchery in 1982 .

\section{DWORSHAK - TEST (T4)}

STEELHEAD

Release date: $5-31-82$

Number juveniles released: 31,915

Marks used - Brand: RAL-1 CWT: 23-16-1

Recovery Area

Adult Trapping Facilities

Bonneville

McNary

Lower Granite
61

17

80
No. of Returns Percent Return

River sport

Columbia $R$. below Snake R.

0.191

Columbia $R$. above Snake $R$.

0

0.053

Snake R.

7

0.251

Clearwater R.

1

0.009

0.0

7

0.022

Indian Fishery

Fall Zone 6

0.169

Winter Zone 6

14

0.044

Clearwater

2

0.006

Ceremonial

0

0.0

Dworshak Hatchery

43

0.135

Other Hatcheries

0

0.0

Stream Survey

1

0.003

Ocean Fishery
Totals
$\frac{1}{284}$
$\frac{0.003}{0.890}$ 
Appendix Table 1 -9.--Summary of adult steelhead marked as juveniles at Dworshak National Fish Hatchery in 1983 .

\section{DWORSHAK - CONTROL (C1)}

STEELHEAD

Release date: 4-20-83

Number juveniles released: 33,178

Marks used - Brand: LAW-1 CWT: 23-16-38

Recovery Area

No. of Returns Percent Return

Adult Trapping Facilities

Bonneville

McNary

Lower Granite
43

7

213

River Sport

Columbia $R$. below Snake $R$.

Columbia R. above Snake $R$.

Snake R.

Clearwater $\mathrm{R}$.

Indian Fishery

F'all Zone 6

Winter Zone 6

Clearwater

Ceremonial

Dworshak Hatchery

Other Hatcheries

Stream Survey

Ocean Fishery

$\begin{array}{ccc}0 & 0.0 \\ 21 & 0.063 \\ 34 & 0.102\end{array}$

3

0.009

0.0

48

0.144

0

0.0

16

0.048

0

0.0

95

0.286

0

0.0

2

0.006

Totals $\frac{0}{482}$

$\frac{0.0}{1.453}$ 
Appendix Table 1 -10.--Summary of adult steelhead marked as juveniles at Dworshak National Fish Hatchery in 1983.

\section{DWORSHAK - TEST (T1)}

STEELHEAD

Release date: 4-20-83

Number juveniles released: 30,341

Marks used - Brand: RAF-1 CWT: 23-16-40

\section{Recovery Area}

Adult Trapping Facilities

Bonnevilite

MoNary

Lower Granite

River Sport

Columbia $R$. below Snake $R$.

Columbia R. above Snake R.

Snake R.

Clearwater R.

Indian Fishery

Fall Zone 6

Winter Zone 6

Clearwater

Ceremonial

Dworshak Hatchery

Other Hatcheries

Stream Survey

Ocean Fishery
No, of Returns Pexcent Return

123

0.405

50

0.165

417

1. 374

12

0.040

0

0.0

30

0.099

41

0.135
151

12

45

0

170

1

2

Totals $\frac{0}{1,054}$
0.498

0.040

0.148

0.0

0.560

0.003

0.007

$\frac{0.0}{3.474}$ 
Appendix Table 1-11.--Summary of adult steelhead marked as juveniles at Dworshak National Fish Hatchery in 1983.

1983 DWORSHAK - TEST (1A)

STEELHEAD

Release date: 4-20-83

Number juveniles released: 28,658

Marks used - Brand: RAZ-1 CWT: 23-16-39

Recovery Area No. of Returns Percent Return

Adult Trapping Facilities

Bonneville

MeNary

Lower Granite
161

50

425

Rivex Sport

Columbia R. below Snake R.

Columbia $R$. above Snake $R$.

Snake R.

Clearwater R.

Indian Fishery

Fall Zone 6

Winter Zone 6

Clearwater

Ceremonial

Dworshak Hatchery

Other Hatcheries

Stream Survey

Ocean Fishery
21

0

33

28

182

16

42

1

171

1

2

Totals $\frac{1}{1,1.34}$
0.562

0.174

1.483
0.073

0.0

0.115

0.098

0.635

0.056

0.147

0.003

0.597

0.003

0.007

$\frac{0.003}{3.957}$ 
Appendix Table 1-12.--Summaxy of adult steelhead marked as juyeniles at Dworshak National Fish Hatchery in 1983.

1983 DWORSHAK - CONTROL (C2)

STEELHEAD

Release date: 5-3-83

Number juveniles released: 32,236

Marks used - Brand: LAH-2 CWT: 23-16-16

Recovery Area

No. of Returns Percent Return

Adult Trapping Facilities

Bonnevilie

0.071

MeNary

0

0.0

Lower Granite

191

0.593

River Sport

Columbia $R$. below Snake R.

2

0.006

Columbia R. above Snake R.

0

0.0

Snake R.

0.037

Clearwater R.

28

0.087

Indian Fishery

Fall Zone 6

34

0.105

Winter Zone 6

0.003

Clearwater

8

0.025

Ceremonial.

0

0.0

Dworshak Hatchery

90

0.279

Other Hatcheries

0

0.0

Stream Survey

1

0.003

Ocean Fishery

Totals $\frac{1}{391}$

0.003

1.213 
Appendix Table 1-13.--Summary of adult steelhead marked as juyeniles at Dworshak National Fish Hatchery in 1983.

\section{DWORSHAK - CONTROL (C2A)}

STEELHEAD

Release date: $5-3-83$

Number juveniles released: $\quad 31,956$

Marks used - Brand: RAF-3 CWT: 23-16-19

\section{Recovery Area}

Adult Trapping Facilities

Bonneville

McNary

Lower Granite

River Sport

Columbia $R$. below Snake $R$.

Columbia $R$. above Snake $R$.

Snake R.

Clearwater R.

Indian Fishery

Fall Zone 6

Winter Zone 6

Clearwater

Ceremonial

Dworshalk Hatchery

Other Hatcheries

Stream Survey

Ocean Fishery
31

1

188

4

0

21

29

61

2

13

0

97

0

0

Totals $\quad \frac{0}{447}$

9

3

Percent Return
0.097

0.003

0.588

0.013

0.0

0.066

0.091

0.191

0.006

0.041

0.0

0.304

0.0

0.0

$\frac{0.0}{1.399}$ 
Appendix Table 1-14.--Summary of adult steelhead marked as juveniles at Dworshak National Fish

Hatchery in 1983.

$$
1983 \text { DWORSHAK - TEST (T2) }
$$

STEELEEAD

Release date: 5-3-83

Number juveniles released: 32,465

Marks used - Brand: RAF-2 CWT: 23-16-17

Recovery Area

No. of Returns Percent Return

Adult Trapping Facilities

Bonneville

McNary

Lower Granite

River Sport

Columbia R. below Snake R.

Columbia R. above Snake $\mathrm{R}$.

Snake R.

Clearwater $R$.

Indian Fishery

Fall Zone 6

176

Winter Zone 6

Clearwater

Ceremonial

Dworshak Hatchery

Other Hatcheries

Stream Survey

Ocean Fishery
136

42

447

23

0

21

29

0.419

0.129

1. 377
27

41

0

173

2

9

Totals $\frac{1}{1,127}$ 
Appendix Table 1-15.--Summary of adult steelhead marked as juveniles at Dworshak National Fish Hatchery in 1983.

\section{DWORSHAK - CONTROL (C3)}

STEELHEAD

Release date: 5-25-83

Number juveniles released: $30 ; 751$

Marks used - Brand: RAF-4 CWT: 23-16-20

Recovery Area

Adult Trapping Facilities

Bonneville

\section{Adult Trapping Hacilities}

MeNary

Lowex Granite
No. of Returns
Pexcent Return

$\begin{array}{ll}2 & 0.007 \\ 0 & 0.0\end{array}$

18

0.059

River Sport

Columbia R. below Snake R.

0.0

Columbia R. above Snake R.

0.0

Snake R.

0

0.0

Clearwater R.

0.023

Indian Fishery

Fall Zone 6

0.010

Winter Zone 6

0

0.0

Clearwater

0

0.0

Cexemonial

0

0.0

Dworshak Hatchery

0.023

Other Hatcheries

0

0.0

Stream Survey

0

0.0

Ocean Fishery

Totals

$\frac{0}{37}$

$\frac{0.0}{0.120}$ 
Appendix Table 1-16.--Summary of adult steelhead marked as juveniles at Dworshak National Fish Hatchery in 1983 .

\section{DWORSHAK - TEST (T3)}

\section{STEELHEAD}

Release date: $5-24-83$

Number juveniles released: 31,906

Maxks used - Brand: LAW-3 CWT: 23-16-18

Recovery Area

No. of Returns Percent Return

Adult Trapping Facilities

Bonneville

McNaxy

Lower Granite

River Sport

Columbia R. below snake R.

Columbia R, above Snake R.

Snake R.

Clearwater R.

Indian Fishery

$$
\begin{aligned}
& \text { Fall Zone } 6 \\
& \text { Winter Zone } 6 \\
& \text { Clearwater } \\
& \text { Ceremonial }
\end{aligned}
$$

Dworshak Hatchery

Other Hatcheries

Stream Survey

Ocean Fishery
12

4

45

0

0

2

2

0.038

0.013

0.141

0.013
0.141




\section{APPENDIX 2}

A Report of the Health Status of Selected Groups of Brood Year 1981 Steelhead Trout (Salmo gairdneri) Raised at the Dworshak National Fish Hatchery. 


\title{
A REPORT OF THE HEALTH STATUS OF SELECTED GROUPS OF BROOD YEAR \\ 1981 STEELHEAD TROUT (SALMO GAIRDNERI) RAISED AT THE \\ DWORSHAK NATIONAL FISH HATCHERY
}

\author{
by \\ A. JIm Chacko, Ph.D. \\ Research Scientist, Flshery Resources \\ and \\ George W. Klontz, D.V.M. \\ Professor, Fishery Resources \\ University of Idaho \\ Moscow, Idaho 83843
}

\author{
to \\ National Oceanic and Atmospheric Administration \\ National Marine Fisheries Service \\ Clarkston, Washington \\ 1 November 1982
}


INTRODUCTION:

This report covers work performed under Contract No. 41 USC 252 (c) (3) during the period 3 March 1982 through 30 September 1982.

OBJECTIVE:

The objective of the study was to assess the general condition of health in groups of juvenile steelhead trout smolts released at intervals from the Dworshak National Fish Hatchery, Ahsaka, Idaho, during the period 23 March 1982 through 28 May 1982. The general condition of health was to be assessed through the following analyses: body (forklength) measurements; $\mathrm{Na}^{+}-\mathrm{K}^{+}$ATPase levels in gill tissues; prevalence of Renibecterium salmoninarum in posterior kidney tissues; and the histopathological conditions existing in the gill, olfactory, and optic tissues.

SAMPLING METHODS:

1) Identification of Sample Groups:

Eight groups of fish were identified for the 1982 sampling. All groups were from egg take \#8 of the 1981 brood, North Fork Clearwater strain of steelhead trout. The eight groups were divided into test and control 1ots, identifled by a freeze-brand, and further divided into four release groups (Table 1). The established release dates were 19 April 1982, 30 April 1982, 19 May 1982, and 31 May 1982. A11 groups were in System II ponds at Dworshak NFH.

2) Sampling Collection and Preparation:

A sampling schedule and sequence were established (Table 2). At sampling time, the required number of fish were selected at random from the designated pond by a dip net and placed into a bucket of water. The fish 
Table 1: Group Identification and numbers during the 1982 sampling perlod at Dworshak NFH.

\begin{tabular}{cccccc}
\hline $\begin{array}{c}\text { Group } \\
\text { no. }\end{array}$ & $\begin{array}{c}\text { Pond } \\
\text { no. }\end{array}$ & $\begin{array}{c}\text { Release } \\
\text { date }\end{array}$ & Brand & $\begin{array}{c}\text { Inftial } \\
\text { head-count }\end{array}$ & $\begin{array}{c}\text { T/C } \\
\text { no. }\end{array}$ \\
\hline 1 & 26 & $4-19-82$ & RA L/4 & 37,113 & T1 \\
2 & 20 & $4-30-82$ & RA L/2 & 36,815 & T2 \\
3 & 16 & $5-19-82$ & RA $)(/ 1$ & 36,887 & T3 \\
4 & 12 & $5-31-82$ & RA L/1 & 37,114 & T4 \\
5 & 24 & $4-19-82$ & RA L/3 & 37,119 & T1A \\
6 & 22 & $4-19-82$ & LA K/3 & 36,826 & $\mathrm{C} 1$ \\
7 & 18 & $4-30-82$ & LA K/2 & 36,764 & $\mathrm{C} 2$ \\
8 & 14 & $5-19-82$ & LA K/1 & 37,131 & $\mathrm{C3}$ \\
\hline
\end{tabular}

a/ $T=$ Test; $C=$ Contro1 
Table 2: Sampling schedule and number of fish per sample by group for 1982 at Dworshak NFH.

\begin{tabular}{|c|c|c|c|c|c|c|}
\hline \multirow[b]{2}{*}{$\begin{array}{c}\text { Sampling } \\
\text { date }\end{array}$} & \multicolumn{6}{|c|}{ Number of fish sampled } \\
\hline & $3 / 23$ & $4 / 8$ & $4 / 19$ & $4 / 29$ & $5 / 17$ & $5 / 28$ \\
\hline \multicolumn{7}{|l|}{$\begin{array}{c}\text { Group } \\
\text { no. }\end{array}$} \\
\hline 1 & & & 30 & & & \\
\hline 2 & & & & 30 & & \\
\hline 3 & & & & & 30 & \\
\hline 4 & 30 & 30 & 30 & 30 & 30 & 60 \\
\hline 5 & & & 30 & & & \\
\hline 6 & & & 30 & & & \\
\hline 7 & & & & 30 & & \\
\hline 8 & & & & & 30 & \\
\hline
\end{tabular}


were taken to the facility laboratory and anesthetized in MS-222 (tricaine methanesulfonate, Ayerst Laboratories). Individual fish were measured (fork length to the nearest $\mathrm{mm}$ ) and exsanguinated by caudal penduncle severance. The first right g111 arch was removed, placed Into a numbered vial containing an ATPase preserving solution and frozen in liquid nitrogen. The second right gill arch was removed and placed Into a numbered vial containing $10 \%$ neutral buffered formalin. Also, into the same vial was placed a portion of the posterior kidney and the head severed just posterior to the eyes. Another portion of the middle and posterior kidney was placed into a numbered plastic bag and frozen at $-40^{\circ} \mathrm{C}$ for subsequent examination for $\underline{R}$. salmoninarum, the causative agent of bacterial kidney disease (BKD).

The 3/23, 4/8, and $4 / 9$ samples for gill $\mathrm{Na}^{+}-\mathrm{K}^{+}$ATPase levels were removed from the liquid nitrogen after 2-3 hours and stored in a Revco freezer at $-25^{\circ} \mathrm{F}$. The $4 / 19,5 / 17$, and $5 / 28$ gill samples were frozen directly in the $-25^{\circ} \mathrm{F}$ freezer.

The frozen gill samples were shipped in dry ice via Greyhound Bus Lines to the MMS Field Station at Cook, Washington (Table 3).

3) Histopathological Methods:

The formalin-fixed gill and kidney tissues were processed through the paraffin vacuum-imbedding technique, sectioned at 5 microns and stained using the alum hematoxylin-eosin $Y$ technique. The formalin-fixed heads were cut sagittally, decalcified, and prepared for staining as in the gill and kidney tissues. Most of the sections were stained using the alum hematoxylin-eosin $Y$ technique, and some were stained using the alum hematoxylin-eosin-phloxine-B technique. 
Table 3: Schedule for submitting frozen g111 samples to the NMFS Cook Field Station.

\begin{tabular}{llc}
\hline $\begin{array}{l}\text { Arr1va1 } \\
\text { date }\end{array}$ & $\begin{array}{l}\text { Sample } \\
\text { group }\end{array}$ & $\begin{array}{c}\text { Sampling } \\
\text { date }\end{array}$ \\
\hline $5 / 26 / 82$ & 1 & $4 / 19$ \\
& 4 & $3 / 23$ \\
& 4 & $4 / 08$ \\
& 4 & $5 / 17$ \\
& 5 & $4 / 19$ \\
$6 / 17 / 82$ & 6 & $4 / 19$ \\
$7 / 02 / 82$ & 4 & $5 / 28$ \\
& & \\
& 2 & $4 / 29$ \\
& 3 & $5 / 17$ \\
& 4 & $4 / 19$ \\
& 4 & $4 / 29$ \\
& 7 & $4 / 29$ \\
& 8 & $5 / 17$ \\
\hline
\end{tabular}


4) Immunofluorescent Method:

On the day of examination, the frozen samples of kidney tissue were thawed. A section was removed and the cut surface Imprinted on a slide and allowed to alr-dry on a slide warmer at $60^{\circ} \mathrm{C}$. Each imprint was overlayed with an amount of appropriately diluted anti-R. salmoninarum conjugated with fluorescein Isothlocyanate serum (National Flisherles Regearch Center, Leestown, West Virginia). The slides were 1ncubated in $100 \%$ humidified chambers for $15 \mathrm{minutes}$ at room temperature $\left(22-24^{\circ} \mathrm{C}\right)$, rinsed through two changes of phosphate buffered saline ( $\mathrm{pH} 7.6$ ), and through two changes of distilled water to remove the saline. After alr-drying, the Imprints were mounted with a PBS-glycerol medium and examined microscoptcally under ofl Immersion. A minimum of $20 \mathrm{flelds}$ per smear were examined, and the number of organloms per fleld recorded.

\section{RESULTS :}

1) Water Temperature:

The water temperatures at the scheduled times decreased from $47.7^{\circ} \mathrm{F}$ $\left(8.72^{\circ} \mathrm{C}\right.$ ) on $23 \mathrm{March}$ to $41.8^{\circ} \mathrm{F}\left(5.44^{\circ} \mathrm{C}\right)$ on 28 May 1982 (Table 4).

Table 4: Water temperatures at the time of the 1982 floh samplings from Dworshak NFH.

Date

23 March

8 Apr 11

19 Apr11

29 Apr11

17 May

28 May
Water temperature $\left({ }^{\circ} \mathrm{F}\right)$

47.7

47.0

42.0

42.5

44.0

41.8 
2) Fork Lengths:

The fork lengths (mm) of Individual fish show a gradual Increase with time (Table 5). This is especially evident when the mean fork lengths and range of fork lengths recorded in the Group 4 samples are examined (Tables 6 and 7).

\section{3) ATPase Analyses:}

The samples taken for $\mathrm{Na}^{+}-\mathrm{K}^{+}$ATPase levels in g111 t1ssues were sent to the NMFS Field Station, Cook, Washington, In three shipments. The first, sent on 25 May 1982, was scheduled to arrive on 26 May 1982; however, it did not arrive until late the following day because of an error In routing during shipment. As a result, some of the samples were thawed and were unsuitable for ATPase determination. The specific samples unsultable were from Group 4 , the $3 / 23$ and 4/8 samples.

In general, there was a gradual increase in gill $\mathrm{Na}^{+}-\mathrm{K}^{+}$ATPase levels during the overall sampling perlod (Tables 8 and 9).

4) Prevalence of Renibacterium salmoninarum:

Using the method of direct Immunofluorescence, $\underline{R}$. salmoninarum, the causative agent of $\mathrm{BKD}$, was detected only in samples collected on 17 May 1982 (Table 10). Since the samples were examined at several points in time by sampling date, it is possible to assume that the reagent(s) were contaminated with R. salmoninarum at that point in time. This assumption 1s somewhat validated by not detecting the organism in any other samplings of Group 4--before or after the 17 May sample. It is further validated by closely examining the histopathological sections of the specific fish Involved and not detecting any evidence of pre-clinical $B K D$. 
Table 5: Fork lengthe of fleh sampled from raceways at Dworahak, NFH prior to the 1982 release.

\begin{tabular}{|c|c|c|c|c|c|c|c|c|c|c|c|c|c|}
\hline $\begin{array}{c}\text { Sampling } \\
\text { date }\end{array}$ & $3 / 23$ & $4 / 8$ & & & 19 & & & $4 / 2$ & & & $5 / 17$ & & $5 / 2 B$ \\
\hline Eond no. & 4 & 4 & $I$ & 4 & 5 & 6 & 2 & 4 & 7 & 3 & 4 & 8 & 5 \\
\hline Flsh no, & & & & & & & & & & & & & \\
\hline 1 & 176 & 181 & $135^{\circ}$ & 132 & 140 & 166 & 120 & 170 & 205 & 137 & 205 & 184 & 130 \\
\hline 2 & 172 & 192 & 201 & 129 & 146 & 190 & 185 & 175 & 140 & 199 & 137 & 205 & 195 \\
\hline 3 & 114 & 134 & 196 & 210 & 189 & 124 & 170 & 185 & 155 & 232 & 202 & 165 & 185 \\
\hline 4 & 154 & 156 & $20 B$ & 136 & 155 & 220 & 155 & 185 & 165 & 202 & 194 & 192 & 195 \\
\hline 5 & 142 & 178 & 184 & 201 & 132 & 155 & 150 & 200 & 165 & 132 & 180 & 174 & 150 \\
\hline 6 & 144 & 215 & 140 & 106 & 216 & 161 & 165 & 205 & 150 & 114 & 126 & 145 & 165 \\
\hline 7 & 163 & 182 & 206 & 204 & 221 & 191 & 135 & 150 & 170 & 187 & 189 & 203 & 160 \\
\hline 8 & 165 & 190 & 142 & 190 & 118 & 196 & 170 & 145 & 185 & 83 & 226 & 186 & 175 \\
\hline 9 & 128 & 174 & 168 & 142 & 105 & 159 & 165 & 170 & 190 & 190 & 176 & 170 & 175 \\
\hline 10 & 261 & 101 & 140 & 197 & 138 & 205 & 200 & 185 & 145 & 127 & 207 & 198 & 195 \\
\hline 11 & 134 & 113 & 190 & 177 & 190 & 179 & 220 & 190 & 160 & 170 & 186 & 168 & 210 \\
\hline 12 & 143 & 160 & 166 & 105 & 168 & 146 & 175 & 190 & 175 & 149 & 192 & 135 & 180 \\
\hline 13 & 166 & 135 & 124 & 190 & 196 & 110 & 160 & 180 & 175 & 207 & 144. & 180 & 145 \\
\hline 14 & 160 & 168 & 172 & 165 & 184 & 224 & 155 & 160 & 190 & 195 & 211 & 200 & 135 \\
\hline 15 & 138 & 139 & 186 & 125 & 158 & 209 & 135 & 165 & 155 & $127^{\circ}$ & 159 & 178 & 195 \\
\hline 16 & 95 & 119 & 182 & 182 & 195 & 152 & 170 & 180 & 205 & 178 & 155 & 128 & 205 \\
\hline 17 & 115 & 121 & 178 & 173 & 171 & 212 & 205 & 160 & 210 & 165 & 170 & 159 & 195 \\
\hline 18 & 199 & 140 & 104 & 198 & 123 & 171 & 185 & 145 & 150 & 218 & 134 & 191 & 190 \\
\hline 19 & 113 & 90 & 194 & 170 & 157 & 185 & 190 & 140 & 175 & 210 & 164 & 185 & 175 \\
\hline 20 & 134 & 195 & 93 & 175 & 149 & 143 & 165 & 175 & 165 & 182 & 196 & 196 & 185 \\
\hline 21 & 164 & 180 & 132 & 149 & 135 & 155 & 155 & 190 & 165 & 109 & 184 & 188 & 150 \\
\hline 22 & 145 & 117 & 204 & 219 & 176 & 178 & 180 & 185 & 190 & 174 & 130 & 150 & 155 \\
\hline 23 & 170 & 115 & 138 & 194 & 231 & 213 & 205 & 185 & 195 & 159 & 173 & 219 & 140 \\
\hline 24 & 138 & 132 & 179 & 191 & 127 & 128 & 210 & $\downarrow 55$ & 205 & 116 & 167 & 165 & 165 \\
\hline 25 & 142 & 120 & 200 & 184 & 170 & 118 & 145 & 140 & 145 & 130 & 150 & 203 & 175 \\
\hline 26 & 157 & 87 & $2\lfloor 7$ & 180 & 174 & 193 & 155 & 210 & 185 & 205 & 220 & 220 & 155 \\
\hline 27 & 119 & 170 & 193 & 188 & 210 & 200 & 170 & 205 & 190 & 215 & 121 & 190 & 190 \\
\hline 28 & 128 & 205 & 127 & 169 & 169 & 135 & 165 & 190 & 160 & 218 & 205 & 218 & 195 \\
\hline 29 & 139 & 185 & 188 & 161 & 160 & 212 & 145 & 160 & 185 & 180 & 139 & 181 & 210 \\
\hline 30 & 116 & 199 & $19 \mathrm{l}$ & 175 & 193 & 188 & 180 & 165 & 170 & 194 & 225 & 234 & 195 \\
\hline 31 & & & & & & & & & & & & & 210 \\
\hline $\begin{array}{l}32 \\
33\end{array}$ & & & & & & & & & & & & & 180 \\
\hline $\begin{array}{l}33 \\
34\end{array}$ & & & & & & & & & & & & & 185 \\
\hline $\begin{array}{l}34 \\
35\end{array}$ & & & & & & & & & & & & & 270 \\
\hline $\begin{array}{l}35 \\
36\end{array}$ & & & & & & & & & & & & & 170 \\
\hline $\begin{array}{l}36 \\
37\end{array}$ & & & & & & & & & & & & & $\begin{array}{l}165 \\
205\end{array}$ \\
\hline 38 & & & & & & & & & & & & & 155 \\
\hline 39 & & & & & & & & & & & & & 210 \\
\hline 40 & & & & & & & & & & & & & 170 \\
\hline 41 & & & & & & & & & & & & & 175 \\
\hline 42 & & & & & & & & & & & & & 180 \\
\hline 43 & & & & & & & & & & & & & 180 \\
\hline 44 & & & & & & & & & & & & & 155 \\
\hline 45 & & & & & & & & & & & & & 205 \\
\hline $\begin{array}{l}46 \\
47\end{array}$ & & & & & & & & & & & & & 185 \\
\hline 47 & & & & & & & & & & & & & 165 \\
\hline 48 & & & . & & & & & & & & & & 170 \\
\hline 49 & & & & & & & & & & & & & 175 \\
\hline 50 & & & & & & & & & & & & & 175 \\
\hline 51 & & & & & & & & & & & & & 155 \\
\hline 52 & & & & & & & & & & & & & 150 \\
\hline 53 & & & & & & & & & & & & & 180 \\
\hline 54 & & & & & & & & & & & & & 200 \\
\hline 35 & & & & & & & & & & & & & 195 \\
\hline 56 & & & & & & & & & & & & & 205 \\
\hline 57 & & & & & & & & & & & & & 180 \\
\hline 58 & & & & & & & & & & & & & 180 \\
\hline 59 & & & & & & & & & & & & & 165 \\
\hline 60 & & & & & & & & & & & & & 160 \\
\hline
\end{tabular}


Table 6: Average fork lengths (mm), range (mm), and standard deviations of lengths in sample groups of fish at Dworshak NFH.

\begin{tabular}{|c|c|c|c|c|}
\hline Lot no. & $\begin{array}{c}\text { Sampling } \\
\text { date }\end{array}$ & $\begin{array}{c}\text { Mean } \\
\text { length (mm) }\end{array}$ & $\begin{array}{l}\text { Length } \\
\text { range }(\mathrm{mm})\end{array}$ & $\begin{array}{l}\text { Standard } \\
\text { deviation }\end{array}$ \\
\hline 1 & 19 Apr11 & 169.26 & $93-217$ & 33.310 \\
\hline 2 & 29 Apr 11 & 169.50 & $120-220$ & 23.647 \\
\hline 3 & 17 May & 170.13 & $83-218$ & 39.176 \\
\hline \multirow[t]{6}{*}{4} & $23 \mathrm{March}$ & 144.47 & $95-176$ & 22.994 \\
\hline & 08 Apri1 & 153.10 & $87-215$ & 36.418 \\
\hline & 19 Apri1 & 170.56 & $129-219$ & 30.097 \\
\hline & 29 April & 174.66 & $140-210$ & 19.736 \\
\hline & 17 May & 175.56 & $121-226$ & 30.905 \\
\hline & 28 May & 177.08 & $130-210$ & 20.696 \\
\hline 5 & 19 Apri1 & 166.53 & $127-221$ & 32.033 \\
\hline 6 & 19 Aprt1 & 173.93 & $110-224$ & 32.388 \\
\hline 7 & 29 Apr11 & 174.00 & $140-210$ & 19.880 \\
\hline 8 & 17 May & 183.60 & $135-204$ & 25.100 \\
\hline
\end{tabular}


Table 7: Mean fork length (mm) and length range (mm) in sample groups by sampling times.

\begin{tabular}{|c|c|c|c|c|c|c|c|c|c|}
\hline \multirow{2}{*}{$\begin{array}{c}\text { Sample } \\
\text { datee }\end{array}$} & \multicolumn{8}{|c|}{ Group } & \multirow[b]{2}{*}{ Mean } \\
\hline & 1 & 2 & 3 & 4 & 5 & 6 & 7 & 8 & \\
\hline $3 / 23$ & & & & $\begin{array}{c}144.47 \\
(96-176)\end{array}$ & & & & & 144.47 \\
\hline $4 / 08$ & & & & $\begin{array}{c}153.10 \\
(87-215)\end{array}$ & & & & & 153.10 \\
\hline $4 / 19$ & $\begin{array}{c}169.26 \\
(93-217)\end{array}$ & & & $\begin{array}{c}170.56 \\
(129-219)\end{array}$ & $\begin{array}{l}166.53 \\
(127-221)\end{array}$ & $\begin{array}{c}173.93 \\
(110-224)\end{array}$ & & & 170.07 \\
\hline $4 / 29$ & & $\begin{array}{c}169.5 \\
(120-220)\end{array}$ & & $\begin{array}{l}174.66 \\
(140-210)\end{array}$ & & & $\begin{array}{l}174.00 \\
(140-210)\end{array}$ & & 172.72 \\
\hline $5 / 17$ & & & $\begin{array}{c}170.13 \\
(83-218)\end{array}$ & $\begin{array}{l}175.56 \\
(121-226)\end{array}$ & & & & $\begin{array}{l}183.6 \\
(135-204)\end{array}$ & 172.85 \\
\hline $5 / 28$ & & & & $\begin{array}{c}177.08 \\
(130-210)\end{array}$ & & & & & 177.08 \\
\hline
\end{tabular}


Toble 8: G111 $\mathrm{Na}^{+}-\mathrm{X}^{+}$ATP-ase levels in steelhead trout sampled from Oworshak, N.F.H. during 1982.

\begin{tabular}{|c|c|c|c|c|c|c|c|c|c|c|c|c|c|}
\hline $\begin{array}{l}\text { Sampling } \\
\text { Dats: }\end{array}$ & $3 / 23$ & $4 / 8$ & & $4 /$ & & & & $4 / 29$ & & & $5 / 17$ & & $5 / 28$ \\
\hline Pond No.: & 4 & 4 & 1 & 4 & 5 & 6 & 2 & 4 & 7 & 3 & 4 & 8 & 4 \\
\hline Fish Ho. & & & & & & & & & & & & & \\
\hline 1 & 5.5 & 5.6 & 5.9 & 12.9 & - & 14.7 & 9.3 & 15.0 & 9.5 & 7.5 & 18.2 & 12.1 & 14.4 \\
\hline 2 & 1.1 & 6.6 & 4.7 & 10.8 & 2.0 & 15.6 & 18.3 & 12.4 & 14.6 & 9.7 & 9.0 & 13.1 & 13.4 \\
\hline 3 & 2.4 & 2.5 & 3.6 & 13.8 & 4.3 & 5.1 & 17.0 & 18.0 & 9.4 & 8.9 & 11.6 & 8.6 & 17.3 \\
\hline 4 & 1.5 & 2.7 & 15.2 & 10.4 & 5.6 & 8.3 & 19.0 & 5.5 & 11.5 & 12.0 & 12.6 & 8.1 & 10.6 \\
\hline 5 & -1.9 & 5.7 & 6.5 & 15.0 & 2.5 & 6.3 & 26.2 & 8.5 & 13.5 & 9.7 & 13.4 & 11.3 & 11.6 \\
\hline 6 & 1.2 & 6.7 & 2.2 & 10.2 & 8.1 & 7.8 & 11.2 & 8.6 & 10.3 & 12.6 & 8.0 & 6.5 & 10.5 \\
\hline 7 & 0.6 & 5.0 & 7.8 & 9.4 & 9.7 & 10.7 & 16.0 & 15.8 & 12.0 & 9.3 & 8.7 & 6.9 & 9.0 \\
\hline 8 & 1.0 & 3.8 & 5.4 & 16.4 & 5.1 & 8.1 & 10.9 & 8.8 & 11.5 & 13.6 & 18.9 & 8.5 & 21.6 \\
\hline 9 & & 2.8 & 7.8 & 10.1 & 2.0 & 7.0 & 11.0 & 10.6 & 8.2 & 15.8 & 21.5 & 14.1 & 4.2 \\
\hline 10 & & 0.8 & 9.3 & 11.5 & 3.2 & 8.2 & 7.7 & 14.5 & 7.8 & 6.9 & 11.6 & 21.2 & 9.7 \\
\hline 11 & & -1.2 & 11.3 & $\$ 6.5$ & 10.2 & 13.3 & 6.3 & 11.8 & 4.8 & 12.8 & 14.5 & 18.6 & • \\
\hline 12 & $\stackrel{4}{\pi}$ & 4.8 & 3.7 & 10.5 & 9.9 & 3.2 & 17.5 & 10.3 & 7.5 & 6.8 & 16.3 & 10.8 & 8.7 \\
\hline 13 & 产 & 2.9 & 3.1 & 13.9 & 7.1 & 5.2 & 6.0 & 7.7 & 4.6 & 18.0 & 10.7 & 17.4 & 10.9 \\
\hline 14 & \& & 0.2 & 7.2 & 9.7 & 12.7 & 9.3 & 11.4 & 7.3 & 10.1 & 12.8 & 10.3 & 9.9 & 9.4 \\
\hline 15 & 蒙 & & 13.4 & 4.4 & 9.5 & 9.7 & 15.3 & 22.7 & 6.3 & - & 11.7 & 18.0 & 22.2 \\
\hline 16 & 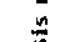 & & 14.6 & 10.3 & 8.0 & 10.0 & 11.8 & 19.9 & 14.3 & 14.3 & 6.7 & 10.7 & 7.5 \\
\hline 17 & 5 & & 7.5 & 8.9 & 7.3 & 21.9 & 12.3 & 14.6 & 5.9 & 10.0 & 12.8 & 16.1 & 4.7 \\
\hline 18 & ธี & $\frac{1}{\underline{E}}$ & - & 8.9 & 3.0 & 11.8 & Mt. ! & 16.8 & 16.7 & 11.3 & 7.0 & 16.7 & 14.9 \\
\hline 19 & $\Phi$ & $\bar{n}$ & 10.6 & 5.6 & 11.4 & 11.2 & 15.1 & 10.7 & $\$ .1$ & 8.3 & 9.7 & 16.9 & 15.1 \\
\hline 20 & $\tilde{5}$ & 8 & 1.8 & 6.4 & 5.4 & 7.8 & 12.7 & 13.5 & 8.1 & 9.8 & 8.9 & 17.1 & 19.9 \\
\hline 21 & $\overline{\breve{d}}$ & 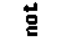 & 1.5 & 5.3 & 6.5 & 10.0 & 9.2 & 0.2 & 10.3 & 3.4 & 16.1 & 12.9 & 16.3 \\
\hline 22 & 1 & $\stackrel{n}{n}$ & 10.2 & 13.1 & 7.6 & 8.5 & 8. 1 & 6.3 & 9.6 & 5.4 & 7.5 & 13.7 & 11.2 \\
\hline 23 & 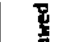 & 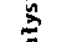 & 4.3 & 6.7 & 13.5 & 4.6 & 10.4 & 5.9 & 8.3 & 7.4 & 6.4 & 17.9 & 10.9 \\
\hline 24 & 3 & 蛋 & 2.2 & 12.3 & 5.3 & 5.9 & 14.6 & 9.8 & 10.1 & 6.0 & 5.0 & 15.7 & 9.8 \\
\hline 25 & u & $\Phi$ & $6.1^{\prime}$ & 8.7 & 5.7 & 0.4 & 9.3 & 4.6 & 11.3. & 4.7 & 4.6 & 12.9 & 10.9 \\
\hline 26 & $\overline{7}$ & 5 & 9.8 & 7.5 & 3.0 & 12.5 & 10.4 & 11.7 & 7.7 & 8.4 & 11.2 & 11.0 & 11.4 \\
\hline 27 & ถึ & $\overline{\breve{~}}$ & 14.8 & 8.9 & 4.8 & 5.1 & 7.2 & 10.9 & 21.8 & 9.5 & 4.8 & 13.5 & 3.4 \\
\hline $2 B$ & & 1 & 6.8 & 9.6 & 4.7 & 9.8 & 9.3 & 11.4 & $: 1.9$ & 11.8 & 8.8 & 18.0 & 12.5 \\
\hline 29 & & $\underline{z}$ & 7,5 & 8.9 & 6.2 & 10.3 & 14.9 & 9.6 & 11.0 & 13.1 & 7.7 & 13.9 & B. 1 \\
\hline 30 & & 혼 & 8.5 & 15,3 & 9.2 & 12,9 & 12.0 & 11,3 & 8.5 & 9.3 & 10.0 & 11.5 & 7.1 \\
\hline 31 & & $y$ & & & & & & & & & & & 7,5 \\
\hline 32 & & $\overline{2}$ & & & & & & & & & & & 12.2 \\
\hline 33 & & 落 & . & & & & & & & & & & 23.9 \\
\hline 34 & & & & & & & & & & & & & 13.2 \\
\hline 35 & & & & & & & & & & & & & 25.5 \\
\hline 36 & & & & & & & & & & & & & 12.8 \\
\hline 37 & & & & & & & & & & & & & 12.9 \\
\hline 38 & & & & & & & & & & & & & 11.5 \\
\hline 39 & & & & & & & & & & & & & 11.9 \\
\hline 40 & & & & & & & & & & & & & 14.3 \\
\hline 41 & & & & & & & & & & & & 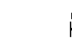 & 15.2 \\
\hline 42 & & & & & & & & & & & & 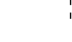 & 11.3 \\
\hline 43 & & & & & & & & & & & & ' & 21.1 \\
\hline 44 & & & & & & & & & & & & & 13.5 \\
\hline 45 & & & & & & & & & & & & & 24.3 \\
\hline 46 & & & & & & & & & & & & & 9.6 \\
\hline $\begin{array}{l}47 \\
48\end{array}$ & & & & & & & & & & & & & 15.0 \\
\hline 49 & & & & & & & & & & & & & 13.3 \\
\hline 50 & & & & & & & & & & & & & 15.0 \\
\hline 51 & & & & & & & & & & & & & 14.2 \\
\hline 52 & & & & & & & & & & & & & 19.9 \\
\hline 53 & & & & & & & . & & & & & & 13.5 \\
\hline 54 & & & & & & & & & & & & & 13.7 \\
\hline 55 & & & & & & & & & & & & & 21.5 \\
\hline 56 & & & & & & & & & & & & & 19.7 \\
\hline 57 & & & & & & & & & & & & & 16.71 \\
\hline 58 & & & & & & & & & & & & & 7.4 \\
\hline 59 & & & & & & & & & & & & & 16.2 \\
\hline 60 & & & & & & . & & & & & & 、 & 13.2 \\
\hline & & & & & & & 13 & & & & & & 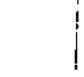 \\
\hline
\end{tabular}


Table 9: Statistical analyses of gill $\mathrm{Na}^{+}-\mathrm{K}^{+}$ATP-ase levels in Dworshak N.F.H. steelhead.

\begin{tabular}{|c|c|c|c|c|c|c|c|c|c|c|}
\hline $\begin{array}{c}\text { Sample } \\
\text { Date }\end{array}$ & & 1 & 2 & 3 & 4 & 5 & 6 & 7 & 8 & Mean \\
\hline $3 / 23 / 82$ & $\begin{array}{l}\text { mean } \\
\text { range } \\
\text { st'd dev. }\end{array}$ & & & & $\begin{array}{c}1.43 \\
-1.9-5.5\end{array}$ & & & & & 1.43 \\
\hline $4 / 8 / 82$ & $\begin{array}{l}\text { mean } \\
\text { range } \\
\text { st'd dev. }\end{array}$ & & & & $\begin{array}{c}3.49 \\
-1.2-6.7\end{array}$ & & & & & 3.49 \\
\hline $4 / 19 / 82$ & $\begin{array}{l}\text { mean } \\
\text { range } \\
\text { st'd dev. }\end{array}$ & $\begin{array}{c}7.49 \\
1.5-15.2 \\
4.02\end{array}$ & & & $\begin{array}{c}10.39 \\
5.3-16.4 \\
10.39\end{array}$ & $\begin{array}{l}6.67 \\
2.0-13.5 \\
3.15\end{array}$ & $\begin{array}{l}9.44 \\
3.2-15.6 \\
3.84\end{array}$ & & & 8.49 \\
\hline $4 / 29 / 82$ & $\begin{array}{l}\text { mean } \\
\text { range } \\
\text { st'd dev. }\end{array}$ & & $\begin{array}{c}12.15 \\
6.0-26.2 \\
4.29\end{array}$ & & $\begin{array}{c}11.42 \\
4.6-22.7 \\
4.31\end{array}$ & & & $\begin{array}{c}10.10 \\
4.8-16.7 \\
3.62\end{array}$ & & 11.22 \\
\hline $5 / 17 / 82$ & $\begin{array}{l}\text { mean } \\
\text { range } \\
\text { st'd dev. }\end{array}$ & & & $\begin{array}{l}9.96 \\
4.7-15.8 \\
3.37\end{array}$ & $\begin{array}{l}10.80 \\
4.6-21.5 \\
4.27\end{array}$ & & & & $\begin{array}{c}13.45 \\
6.5-21.2 \\
3.82\end{array}$ & 11.40 \\
\hline $5 / 28 / 82$ & $\begin{array}{l}\text { mean } \\
\text { range } \\
\text { st'd dev. }\end{array}$ & & & & $\begin{array}{c}13.36 \\
4.2-25.5 \\
4.99\end{array}$ & & & & & 13.36 \\
\hline
\end{tabular}


Table 10. Prevalence of Renibacterium salmoninarum in posterior kidney tissues of steel head from Dworshak N.F.H.

\begin{tabular}{|c|c|c|c|c|c|c|c|c|}
\hline Sampling & & & & Sample & & & & \\
\hline Date & 1 & 2 & 3 & & 5 & 6 & 7 & 8 \\
\hline 3/23/82 & & & & $0 / 30$ & & & & \\
\hline $4 / 8 / 82$ & & & & $0 / 30$ & & & & \\
\hline $4 / 19 / 82$ & $0 / 30$ & & & $0 / 30$ & $0 / 30$ & $0 / 30$ & & \\
\hline $4 / 29 / 82$ & & $0 / 30$ & & $0 / 30$ & & & $0 / 30$ & \\
\hline $5 / 17 / 82$ & & & $1 / 30$ & $6 / 30$ & & & & $1 / 30$ \\
\hline $5 / 28 / 82$ & & & & $0 / 60$ & & & & \\
\hline
\end{tabular}




\section{5) H1gtopathological Examinations:}

In general, there were no signiftcant life-compromising histopathological changes observed in glils, kldneys, nasal sac, and post-orbital t1ssues (Table 11). The most consistent finding in the gill t1ssues was a mild to moderate lamellar hypertrophy, to which no clinical BIgnificance was attached. In one sampling (Group 4 on 4/19), there were oeveral flah exhiblting lameliar necrosis. The clintcal significance of this 18 unkown, but given the general histopathological conditions of the kldney, nasal, sac, and post-orblt tissues, it is unlikely that the gill condition was anything more than transitory.

The most consistent finding in the kidney tissues was a mild to moderate generalized fatty infiltration which was probably due more to dietary composition rather than to renal dysfunction, given the condition of the renal tubules and glomerulf. There were 1solated Instances of mild to moderate hydropic changes in the renal tubules, but no clinical signiflcance was attached to this given the lack of more sertous lesions in the renal tissues.

The nasal sac and post-orbit t1ssues were consistently without abnormalit1es. The observations of free blood in the nasal cavities of some samples was probably due to hemorrhage induced through sampling technique because the underlying t1ssue were without rotable degenerative changes.

\section{CONCLUSIONS :}

Based upon the foregoing physical, physiological, and histopathological observations, there is no reason to assume that the fish sampled were anything other than clinically healthy. 'Throughout the 420 
Table 11: Histopathological changes in gill, kidney, nasal sac, and post-orbital tissues of steelhead sampled in 1982 from Dworshak N.F.H.

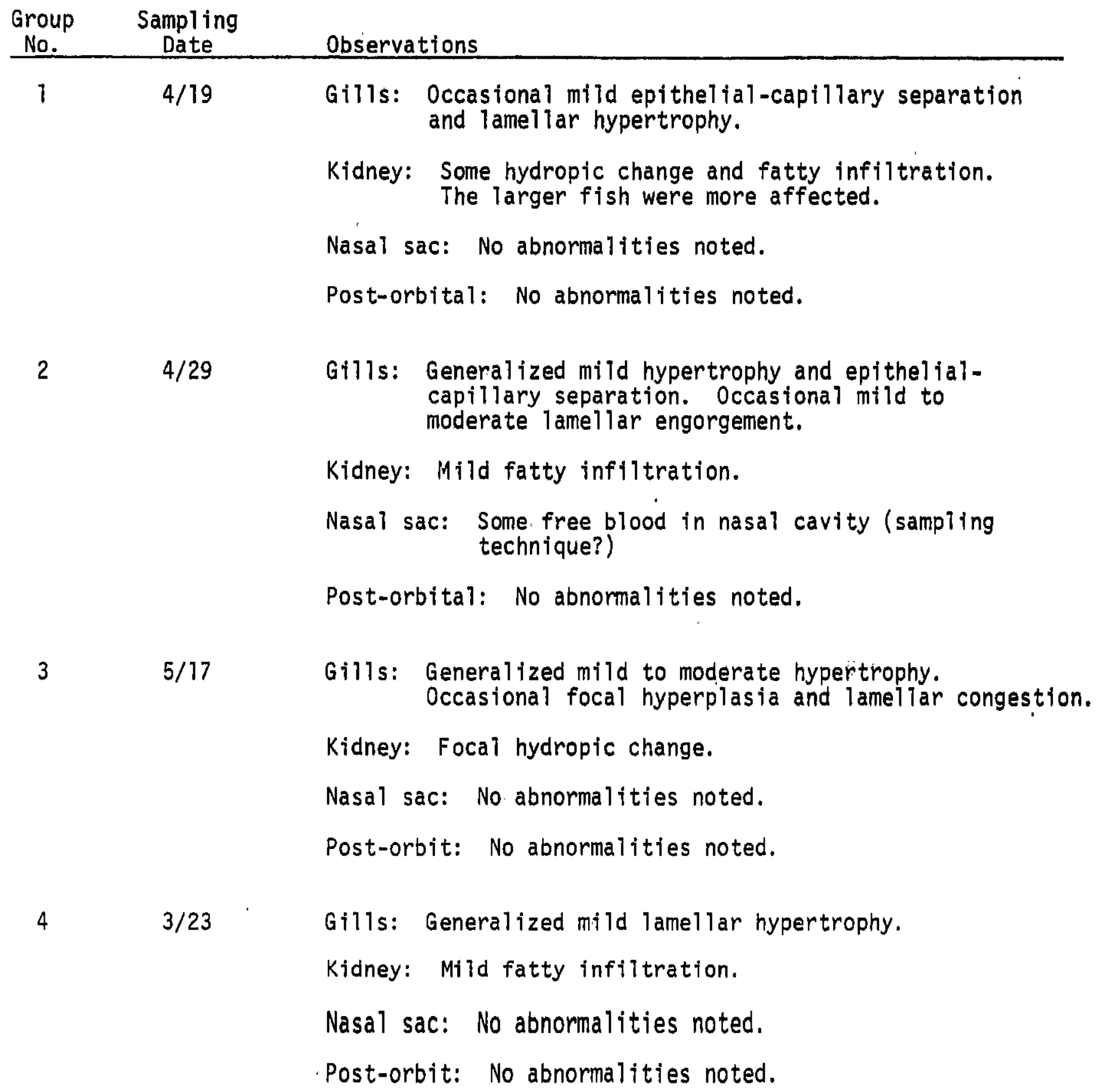


Table 11: Continued

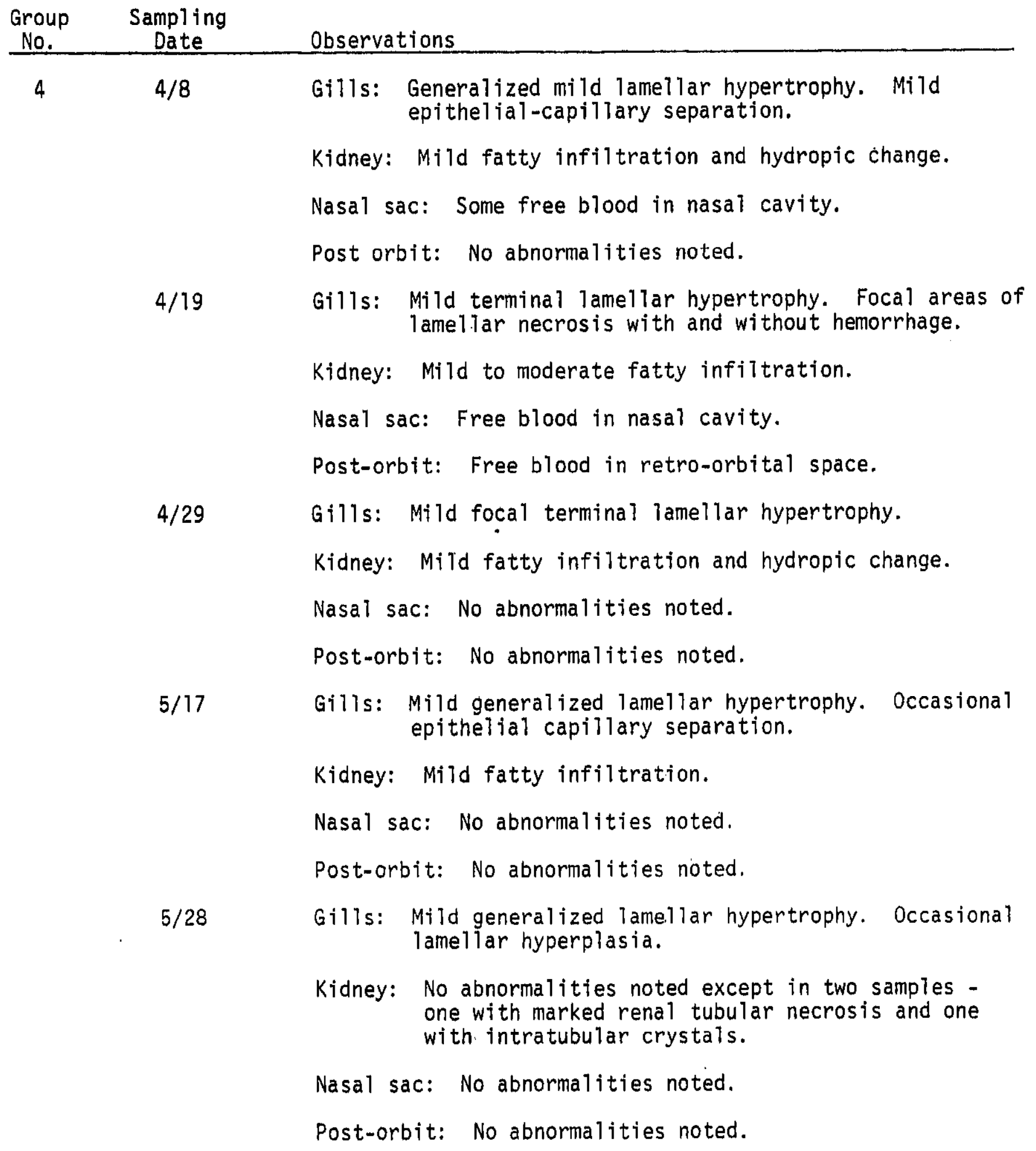


Table 11: Continued

\begin{tabular}{|c|c|c|}
\hline $\begin{array}{l}\text { Group } \\
\text { No. }\end{array}$ & $\begin{array}{l}\text { Sampling } \\
\text { Date }\end{array}$ & Observations \\
\hline \multirow[t]{3}{*}{5} & $4 / 19$ & $\begin{array}{l}\text { Gills: Mild to moderate generalized lamellar hypertrophy. } \\
\text { Occasional lamellar engorgement and lamellar } \\
\text { hyperplasia. }\end{array}$ \\
\hline & & $\begin{array}{l}\text { Kidney: Mild to moderate fatty infiltration and hydropic } \\
\text { change. }\end{array}$ \\
\hline & & $\begin{array}{l}\text { Nasal sac: No abnormalities noted. } \\
\text { Post-orbit: No abnormalities noted. }\end{array}$ \\
\hline \multirow[t]{3}{*}{6} & $4 / 19$ & $\begin{array}{l}\text { Gills: Moderate lamellar necrosis with hemorrhage. } \\
\text { One sample with a mild Dermocystidium infection. }\end{array}$ \\
\hline & & $\begin{array}{l}\text { Kidney: Mild to moderate fatty infiltration and hydropic } \\
\text { change. }\end{array}$ \\
\hline & & $\begin{array}{l}\text { Nasal sac: Some samples with free blood in nasal cavity. } \\
\text { Post-orbit: No abnormalities noted. }\end{array}$ \\
\hline 7 & $4 / 29$ & $\begin{array}{l}\text { Gills: Mild generalized hypertrophy. } \\
\text { Kidney: Mild.generalized fatty infiltration. } \\
\text { Nasal sac: No abnormalities noted. } \\
\text { Post-orbit: No abnormalities noted. }\end{array}$ \\
\hline \multirow[t]{2}{*}{8} & $5 / 17$ & $\begin{array}{l}\text { Gilis: Mild focal lamellar hypertrophy. Several fish with } \\
\text { moderate epithelial capillary separation. }\end{array}$ \\
\hline & & $\begin{array}{l}\text { Kidney: Mild generalized fatty infiltration. } \\
\text { Nasal sac: No abnormalities noted. }\end{array}$ \\
\hline
\end{tabular}


fish examined intensively, there was not a single indication of a potentially Iife-compromising condition. The gill tissues were in the best condition of any ever examined from a hatchery environment.

If there were one recommendation to be made from these observations, it would be to evaluate the influence of dietary composition and feeding rate on the presence of fatty. infiltration in the kidney. Another suggestion would be to examine more fish from more facilities to gain a broader base of knowledge. 


\section{APPENDIX 3}

A Report on the Health Status of Dworshak National Fish Hatchery Steelhead Trout (Salmo gairdneri) used in the National Marine Fisheries Service Transportation-Homing Study (Production Year 1982-1983). 


\begin{abstract}
A Report on the Heal th Status of
Dworshak National Fish Hatchery

Steel head Trout (Salmo gairdneri). used in the National Marine Fisheries Service Transportation-Homing Study (Production Year 1982-1983).
\end{abstract}

by

\author{
Terence M. Bradley \\ Research Biologist \\ Dworshak Fish Health Center
}

and

Joseph C. Lientz

Fish Disease Biologist (Division III) Dworshak Fish Heal th Center

September 28, 1983 


\section{INTRODUCTION}

The importance of rearing a high-quality smolt has been realized in recent years. The release of large numbers of disease-infected or physiologicallyinferior anadromous salmonids has resulted in poor adult returns. The additional stress of dam passage and/or transporation of downstream migrating smolts has emphasized the need for heal thy fish.

This project was undertaken to assess the health status of the steelhead trout reared at Dworshak National Fish Hatchery (DNFH) and used in the National Marine Fisheries Service (NMFS) transportation-homing study.

The report covers work performed under Contract No. 41 USC $252(\mathrm{c})(4)$ during the period March 1, 1982 through September 1, 1982. 


\section{METHODS AND MATERIALS}

Eight groups of juvenile steelhead trout reared at DNFH during production year 1982-1983 were selected for the experiment. Each group consisted of $28,000-40,000$ fish reared in separate $17^{\prime} \times 70^{\prime}$ Burrows recirculating ponds in system II. The juvenile steelhead trout were maintained on single-pass raw water from 06/01/82-11/19/82, 90 percent reused water from 11/19/82$04 / 06 / 83$, and returned to raw water prior to release on the selected dates. The fish were hand fed an OMP diet 8-10 times daily. A1l reused water was passed through large biofiltration beds to reduce environmental ammonia $\left(\mathrm{NH}_{3}-\mathrm{N}\right)$ and nitrite $\left(\mathrm{NO}_{2}-\mathrm{N}\right)$ concentrations. Measurements of $\mathrm{NH}_{3}-\mathrm{N}$ by direct nesslerization and $\mathrm{NO}_{2}-\mathrm{N}$ by the sulfanilamide-NEDA method were made three times weekly. Average environmental ammonia and nitrite concentrations were $0.48+0.24$ and $0.022 \pm 0.014$, respectively. A mineral supplement of $20-30 \mathrm{mg} / \ell$ $\mathrm{Na}+, 5-10 \mathrm{mg} / \ell \mathrm{Kt}$, and $30-40 \mathrm{mg} / \ell \mathrm{Cl}^{-}$was added to the water from $11 / 19 / 82-$ $04 / 06 / 83$. The eight groups of fish were nose tagged, freeze branded and adjpose clipped during December, 1982. Marking operations were supervised by $\mathrm{Mr}$. Steve Achord (NMFS, Clarkston, Washington).

Assessment of the physiological condition of the steelhead was based on the measurement of length, weight, condition factor, hematocrit, gill $\mathrm{Na}+\mathrm{K}+$ ATPase activity and plasma $\mathrm{Na}+$ and $\mathrm{K}+$ concentrations. The disease status was determined by general macro- and microscopic examination, incidence of bacterial kidney disease (Renibacterum salmoninarum) and histological examination of gills, kidneys, livers and nasal epithelium. Blood parameters and gill $\mathrm{Na}+\mathrm{K}+$ ATPase activities were assayed every two weeks for group 4 fish (pond 36) and several days prior to release in groups $1,2,3,5,6,7$, and 8. Blood samples were withdrawn from 16 fish at each sample point. Thirty fish were sampled for gi1l $\mathrm{Na} / \mathrm{K}+$ ATPase activities at each point except the last sampling of group 4 which contained 60 fish. Gross examination and histological samples consisted of 60 fish from group 4 and 30 fish from groups $1,2,3,5,6,7$, and 8 prior to release. 
The juvenile steelhead trout were randomly dipnetted from the ponds and anesthetized in a $75 \mathrm{mg} / \ell$ solution of tricaine methanesulfonate (MS-222, Argent Chemicals). Total length and weight were measured to the nearest millimeter and gram respectively. The condition factor was calculated using the formula $K=$ weight $(\mathrm{g}) /$ length ${ }^{3}(\mathrm{~cm})$. Blood samples were withdrawn from the caudal artery using a heparinized 1 . Occ tuberculin with a $25 \mathrm{~g} \times 5 / 8^{\prime \prime}$ needle (Pharmasea 1). The syringe was gently hand rolled to ensure mixing of heparin and blood and placed on ice. The syringe needle was removed to prevent hemolysis and the whole blood was gently injected into $350 \mu l$ caraway tubes (VWR). The samples were centrifuged in a Beckmann TJ-6R centrifuge at $4^{\circ} \mathrm{C}$ for fifteen minutes at $2,000 \times \mathrm{g}$. The tubes were cut above the plasma/ erythrocyte interface and the plasma placed in $0.5 \mathrm{ml}$ cups (VWR). Plasma was stored at $-25^{\circ} \mathrm{C}$ until assayed. The plasma $\mathrm{Na}+$ and $\mathrm{K}+$ concentrations were measured on a Radiometer FLM-3 Flame Photometer. Hematocrits were determined with a IEC microcapillary centrifuge and reader.

Immediately after blood sampling, approximately $0.1 \mathrm{~g}$ of gill tissue was excised from the gill arches on the right side. The gill filaments were placed in $1.0 \mathrm{ml}$ of a cold $\left(4^{\circ} \mathrm{C}\right)$ solution containing: $0.3 \mathrm{M}$ sucrose, $0.02 \mathrm{M}$ $\mathrm{Na}_{2}$ EDTA and $0.1 \mathrm{M}$ imidazole. An additional group of fish were sampled to reach the required sample number. The filaments were quickly placed in a $-25^{\circ} \mathrm{C}$ freezer and transferred to a $-80^{\circ} \mathrm{C}$ freezer within 24 hours. Frozen gill samples were shipped on dry ice via Greyhound Bus Lines to the NMFS Field Station at Cook, Washington. Gill Na+/K+ ATPase activities were assayed by Dr. Waily Zaugg using the method of Zaugg (1982).

Thirty fish from groups $1,2,3,5,6,7$, and 8 and sixty fish from group 4 were sampled for histology prior to release. Gill sections for histological examination were excised from the fish and placed in Bouin's fixative for 24 hours and transferred to 70 percent ETOH. A section of the posterior kidney, the liver and the head (severed behind the eyes) were treated in a simlar manner. The samples were completely dehydrated, embedded in paraffin and sections were cut at $5 \mu \mathrm{m}$ and stained with hematoxylin and eosin-phloxine. 
The prepared samples were examined by light microscopy. Histopathological examinations were conducted by Mr. Charlie Smith and Mr. John Morrison of the U.S. Fish and Wildlife Service Development Center at Bozeman, Montana.

During the sampling for histology, a small portion of the middle and posterior kidney was removed for determination of the incidence of Renibacterum salmoninarum. The sections were immediately placed and subsequently stored in 10 percent neutral buffered formalin. Slides were prepared by making a smear with a freshly-cut tissue section, air drying the slide and fixing it in absolute methanol for 10 minutes. The fixed slides were stored in a $-25^{\circ} \mathrm{C}$ freezer. The incidence of Renibacterum salmoninarum was determined using the direct fluorescent antibody test (F.A.T.) as previously described (Bullock and Stuckey, 1975). Conjugate for direct F.A.T. was supplied by the Biologics Lab at the U.S. Fish and Wildlife Service National Fisheries Research Center at Leetown, West Virginia. Material from a kidney lesion in a known infected fish was used as a positive control. Approximately 100 fields per smear were examined with an American Optics fluorescent microscope. The rating of the incidence of Renibacterum salmoninarum was based on an arbitrary scale of 0-4. Negative samples were given a value of 0, 1-3 bacteria/field a +1 , 4-10 bacteria/field a $+2,11-25$ bacteria/field a +3 , and greater than 25 bacteria/field a rating of +4 .

Gross examination of the fish at each sample point was conducted by Mr. Joseph C. Lientz (Division 3 Fish Disease Biologist, U.S. Fish and Wildlife Service). The gills and mucous were examined for parasites and abnormalities by light microscopy. The general condition of the fins, coloration, descaling and mucous consistency were noted. The internal organs were examined for any abnormalities, and bacterial smears were made if warranted. 


\section{RESULTS}

The pond number, brand, release date and population size of each group is presented in Table 1. Group 7 had the largest number of fish $(40,394)$ and group 5 the least number $(28,979)$. The sample dates and numbers are listed in Table 2. The mean length \pm standard deviation and mean weight \pm standard deviation are presented in Table 3. All groups attained a mean size of $>190 \mathrm{~mm}$ by release; mean lengths ranged from 192-210mm. The minumum mean weight was $64+15.6 \mathrm{~g}$, the maximum $80.7 \pm 21.5 \mathrm{~g}$. Table 4 ists the mean \pm standard deviation of weekly measurements $(3 x /$ week) of water temperature, $\mathrm{pH}$, dissolved oxygen and $\mathrm{NH}_{3}-\mathrm{N}$ concentrations.

The following sections report the data for the individual parameters and groups :

Plasma $\mathrm{Na}+$ and $\mathrm{K}+$ Concentrations and Hematocrits

The mean \pm standard deviation of plasma $\mathrm{Na}+$ and $\mathrm{K}+$ concentrations and hematocrit values are depicted in Table 5. All individual and mean plasma $\mathrm{Na}+$ concentrations are within the normal range for stee ihead trout smolts at DNFH. A peak in plasma Na+ concentrations was observed in group 4, fish on $03 / 17 / 83$. This shift has been shown to be indicative of smoltification changes in steelhead trout at DNFH by Bradley and Rourke (1983). All groups sampled after this date have lower plasma Nat concentrations, similar to group 4 values after the peak.

A number of fish in groups 1 (6 fish), 2 (2), 3 (7), 5 (11), 6 (7), 7 (1), and 8 (1) were found to have abnormally low plasma $K+$ concentrations. Group 4 also contained several individuals with low $K+$ levels on the following sample dates: $3 / 1$ ( $1 \mathrm{fish}$ ), 3/31 (3 fish), 4/19 (4 fish), and 5/19 (3 fish).

All individual hematocrit values were within the normal expected range. A total of eight individuals had values less than 30 percent. 


\begin{tabular}{cccccccc} 
Group No. & Pond No. & Brand & No. of Fish & Size (No./lb) & $\begin{array}{c}\text { Total } \\
\text { Length (mm) }\end{array}$ & Weight (1bs) & Release Date \\
\hline 1 & 28 & RAF-1 & 30,544 & 5.95 & 198 & 5,133 & $04-20-83$ \\
2 & 40 & RAF-2 & 34,741 & 5.55 & 204 & 6,260 & $05-03-83$ \\
3 & 36 & RAF-3 & 33,364 & 6.17 & 198 & 5,408 & $05-03-83$ \\
4 & 34 & RAF-4 & 31,240 & 5.74 & 207 & 5,442 & $05-25-83$ \\
5 & 30 & RAZ-1 & 28,979 & 5.91 & 200 & 4,903 & $04-20-83$ \\
6 & 32 & LAW-1 & 33,321 & 6.84 & 188 & 4,872 & $04-20-83$ \\
7 & 42 & LAW-2 & 40,394 & 5.36 & 197 & 7,536 & $05-03-83$ \\
8 & 38 & LAW-3 & 34,656 & 6.19 & 204 & 5,599 & $05-24-83$ \\
\hline
\end{tabular}

Table 1. The brand, number, size, total length, weight and release date of the 8 groups of steelhead trout.

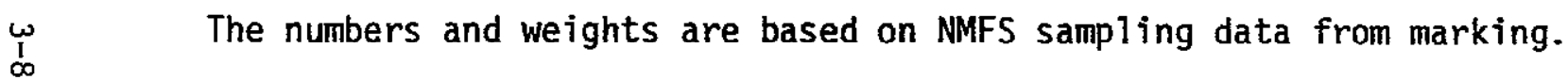




$\begin{array}{ccc}\text { Group No. } & \text { Sample Date } & \text { No. of Fish } \\ 1 & 04-20-83 & 30 \\ 2 & 04-29-83 & 30 \\ 3 & 05-02-83 & 30 \\ 4 & 03-01-83 & 30 \\ & 03-17-83 & 30 \\ & 03-31-83 & 30 \\ & 04-14-83 & 30 \\ 5 & 04-19-83 & 30 \\ 6 & 05-05-83 & 30 \\ 7 & 05-19-83 & 60 \\ 8 & 04-20-83 & 30 \\ & 04-20-83 & 30 \\ & 05-04-83 & 30 \\ & 05-24-83 & 30\end{array}$

Table 2. The sample date and number of individuals sampled for the 8 groups. 


\begin{tabular}{|c|c|c|c|c|c|}
\hline Group No. & $\begin{array}{l}\text { Sampling } \\
\text { Date }\end{array}$ & $\begin{array}{l}\text { Total Length (mm) } \\
\bar{x} \pm \mathrm{SD}\end{array}$ & $\begin{array}{l}\text { Total Length } \\
\text { Range }(\mathrm{mm})\end{array}$ & $\begin{array}{l}\text { Weight }(g) \\
x \pm S D\end{array}$ & $\begin{array}{l}\text { Weight } \\
\text { Range }(g)\end{array}$ \\
\hline 1 & $04-20-83$ & $192 \pm 26$ & $136-237$ & $68.8 \pm 26.4$ & $22.4-123.9$ \\
\hline 2 & $04-29-83$ & $205 \pm 21$ & $154-235$ & $77.7 \pm 21.3$ & $36.6-128.0$ \\
\hline 3 & $05-02-83$ & $205 \pm 17$ & $181-246$ & $74.7 \pm 18$ & $52.8-126.2$ \\
\hline \multirow[t]{7}{*}{4} & $03-01-83$ & $182 \pm 16$ & $141-211$ & $60.2 \pm 14.9$ & $27.5-92.0$ \\
\hline & $03-17-83$ & $184 \pm 19$ & $133-216$ & $61.8 \pm 17.4$ & $22.2-97.2$ \\
\hline & $03-31-83$ & $193 \pm 20$ & $140-232$ & $68.7 \pm 20.2$ & $26.9-113.4$ \\
\hline & $04-14-83$ & $203 \pm 4$ & $166-234$ & $78.7 \pm 3.7$ & $43.4-113.3$ \\
\hline & $04-19-83$ & $201 \pm 20$ & $164-244$ & $78.6 \pm 21.6$ & $39.1-133.3$ \\
\hline & $05-05-83$ & $204 \pm 13$ & $179-228$ & $77.6 \pm 16.8$ & $53.6-121.0$ \\
\hline & $05-19-83$ & $210 \pm 16.8$ & $182-248$ & $80.7 \pm 21.5$ & $49.2-145.4$ \\
\hline 5 & $04-20-83$ & $200 \pm 25.5$ & $152-247$ & $75.4 \pm 25.3$ & $32.5-135.6$ \\
\hline 6 & $04-20-83$ & $192 \pm 17$ & $141-234$ & $66.9 \pm 17.3$ & $27.2-126.1$ \\
\hline 7 & $05-04-83$ & $197 \pm 16$ & $164-231$ & $64 \pm 15.6$ & $38.4-101.0$ \\
\hline 8 & $05-24-83$ & $203 \pm 16$ & $171-248$ & $70.1 \pm 18.2$ & $34.0-122.7$ \\
\hline
\end{tabular}

Table 3. The means \pm standard deviations of Tength $(\mathrm{mm})$ and weight $(\mathrm{g})$, and the length and weight ranges at each sample date. Each value is the mean of 30 individuals except group 4 (05-19-83) which is 60 individuals. 


\begin{tabular}{lcccc} 
Date & Temperature $\left({ }^{\circ} \mathrm{F}\right)$ & $\begin{array}{l}\text { Dissolved } \\
\text { oxygen }(\mathrm{mg} / \mathrm{l})\end{array}$ & $\mathrm{pH}$ & $\begin{array}{c}\mathrm{NH}_{3}-\mathrm{N} \\
(\mathrm{mg} / \mathrm{l})\end{array}$ \\
\hline $03 / 01$ & $52.0 \pm 4.9$ & $10.2 \pm 0.90$ & $6.75 \pm 0.13$ & $0.52 \pm 0.07$ \\
$03 / 08$ & $48.5 \pm 0.5$ & $11.0 \pm 0.11$ & $6.63 \pm 0.29$ & $0.33 \pm 0.09$ \\
$03 / 15$ & $47.0 \pm 0.0$ & $11.2 \pm 0.20$ & $6.85 \pm 0.10$ & $0.49 \pm 0.16$ \\
$03 / 22$ & $47.2 \pm 0.8$ & $11.3 \pm 0.20$ & $6.57 \pm 0.32$ & $0.34 \pm 0.06$ \\
$03 / 29$ & $46.0 \pm 1.8$ & $11.4 \pm 0.3$ & $6.78 \pm 0.15$ & $0.34 \pm 0.06$ \\
$04 / 05$ & $42.0 \pm 0.0$ & $12.3 \pm 0.4$ & $6.40 \pm 0.14$ & $0.12 \pm 0.03$ \\
$04 / 12$ & $40.7 \pm 1.1$ & $12.6 \pm 0.0$ & $6.95 \pm 0.26$ & $0.12 \pm 0.03$ \\
$04 / 19$ & $43.8 \pm 3.2$ & $11.8 \pm 0.9$ & $6.80 \pm 0.33$ & $0.21 \pm 0.13$ \\
$04 / 26$ & $45.0 \pm 0.9$ & $10.2 \pm 0.2$ & $7.18 \pm 0.10$ & $0.32 \pm 0.06$ \\
$05 / 03$ & $46.2 \pm 1.0$ & $9.9 \pm 0.1$ & $7.00 \pm 0.26$ & $0.30 \pm 0.06$ \\
$05 / 10$ & $47.2 \pm 1.0$ & $10.8 \pm 0.8$ & $6.90 \pm 0.40$ & $0.16 \pm 0.03$ \\
$05 / 17$ & $48.3 \pm 0.6$ & $11.7 \pm 0.1$ & $7.20 \pm 0.15$ & $0.13 \pm 0.03$ \\
$05 / 24$ & $50.0 \pm 0.5$ & $11.1 \pm 0.3$ & $7.02 \pm 0.41$ & $0.13 \pm 0.09$
\end{tabular}

Table 4. Water temperature, dissolved oxygen concentration, $\mathrm{pH}$, and $\mathrm{NH}_{3}-\mathrm{N}$ concentration of System II for each week of the study. Each value is the mean \pm standard deviation of three readings/week. 


\begin{tabular}{ccccc} 
Group No. & Date & $\begin{array}{c}\mathrm{Na}+ \\
(\mathrm{mEq} / \mathrm{l})\end{array}$ & $\begin{array}{c}\mathrm{K}+ \\
(\mathrm{mEq} / \mathrm{l})\end{array}$ & $\begin{array}{c}\text { Hct } \\
(\%)\end{array}$ \\
\hline 1 & $04-20-83$ & $159 \pm 2$ & $0.9 \pm 0.3$ & $38 \pm 3$ \\
2 & $04-29-83$ & $152 \pm 1$ & $1.2 \pm 0.1$ & $38 \pm 1$ \\
3 & $05-02-83$ & $153 \pm 3$ & $0.7 \pm 0.3$ & $37 \pm 3$ \\
4 & $03-01-83$ & $158 \pm 4$ & $1.4 \pm 0.4$ & $39 \pm 3$ \\
& $03-17-83$ & $167 \pm 2$ & $2.0 \pm 0.1$ & $32 \pm 4$ \\
& $03-31-83$ & $164 \pm 1$ & $1.3 \pm 0.2$ & $34 \pm 0.8$ \\
& $04-14-83$ & $157 \pm 1$ & $1.9 \pm 0.6$ & $35 \pm 1$ \\
& $04-19-83$ & $157 \pm 5$ & $1.2 \pm 0.4$ & $38 \pm 4$ \\
& $05-05-83$ & $158 \pm 4$ & $1.8 \pm 0.3$ & $35 \pm 3$ \\
& $05-19-83$ & $161 \pm 3$ & $1.6 \pm 0.8$ & $38 \pm 3$ \\
6 & $04-20-83$ & $156 \pm 4$ & $0.7 \pm 0.4$ & $39 \pm 5$ \\
7 & $04-20-83$ & $155 \pm 4$ & $0.9 \pm 0.5$ & $38 \pm 3$ \\
8 & $05-04-83$ & $156 \pm 2$ & $1.4 \pm 0.4$ & $36 \pm 2$ \\
& $05-24-83$ & $158 \pm 3$ & $1.6 \pm 0.4$ & $36 \pm 3$
\end{tabular}

Table 5. Plasma $\mathrm{Nat}$ and $\mathrm{K}+$ concentrations and hematocrit values of the test groups. Each value is the mean \pm standard deviation of 15 individuals. 
The plasma. $\mathrm{Na}+$ and $\mathrm{K}+$ concentrations and hematocrit values for each individual fish are listed in Appendix A.

\section{Gill $\mathrm{Na}+/ \mathrm{K}+$ ATPase Activity and Condition Factor}

A statistically significant increase in gill $\mathrm{Na}+/ \mathrm{K}+$ ATPase activity and decrease in condition factor occurred in group 4 during the monitoring period. Table 6 presents the mean \pm standard deviations of gill $\mathrm{Na}+/ \mathrm{K}+$ ATPase activity and condition factor. Activities in group 4 increased significantly from $5.6 \pm 1.2 \mu$ moles ATP hydrolyzed/mg protein/hr on $3 / 1$ to $13.2+4.7$ on 5/5. The mean ATPase activities of group 4 at release were slightly lower (11.5+3.2) than activities from fish sampled on $5 / 5(13.2 \pm 4.7)$. The ATPase activities of four individuals $(19.9,20.5,23.0,35.0)$ from group $1(4 / 20)$ are much higher than activities in the other individuais in the group. In group $2(4 / 29)$, five abnormally-low ATPase activities were recorded. Two ATPase values are missing in group 5 because of loss of the sample during the assay. All other individuals appear to have gill $\mathrm{Na}+\mathrm{K}+$ ATPase activities within the normal range.

The mean condition factor of group 4 fish decreased significantly from $0.98+0.05$ on March 1 to $0.85+0.06$. This decrease in condition factor was consistent in other groups; the later the release date, the lower the mean condition factor. Indịvidual gill $\mathrm{Na}+\mathrm{K}+$ ATPase activities and condition factors can be found in Appendix A.

\section{Incidence of Renibacterium salmoninarum}

The incidence of Renibacterium salmoninarum for each group is presented in Table 7. The highest rating for any individual using the previously described $0-4$ system was a +1 . All eight groups had at least 2 positive $(+1)$ samples; the highest incidence was 5 positive $(+1)$ samples in a 30 fish sample (group 5 ). The percentage of infected fish ranged from 6.7 percent for group 8 to 16.7 percent for group 5 . No gross kidney lesions or abnormalities were 


\begin{tabular}{|c|c|c|c|c|}
\hline Group No. & Date & $\mu$ moles & $\begin{array}{l}\text { ATPase } \\
\text { ATP hydrolyzed } / \mathrm{mg} \\
\text { protein } / \mathrm{hr}\end{array}$ & Condition Factor \\
\hline 1 & $04-20-83$ & & $11.5 \pm 6.2$ & $0.93 \pm 0.05$ \\
\hline 2 & $04-2.9-83$ & & $9.3 \pm 2.0$ & $0.89 \pm 0.07$ \\
\hline 3 & $05-02-83$ & & $13.1 \pm 3.6$ & $0.85 \pm 0.04$ \\
\hline \multirow[t]{7}{*}{4} & $03-01-83$ & & $5.6 \pm 1.2$ & $0.98 \pm 0.05$ \\
\hline & $03-17-83$ & & $5.5 \pm 1.0$ & $0.96 \pm 0.07$ \\
\hline & $03-31-83$ & & $6.9 \pm 1.7$ & $0.93 \pm 0.04$ \\
\hline & $04-14-83$ & & $8.1 \pm 1.1$ & $0.93 \pm 0.05$ \\
\hline & $04-19-83$ & & $8.9 \pm 1.7$ & $0.95 \pm 0.04$ \\
\hline & $05-05-83$ & & $13.2 \pm 4.7$ & $0.90 \pm 0.05$ \\
\hline & $05-19-83$ & & $11.5 \pm 3.2$ & $0.85 \pm 0.06$ \\
\hline 5 & $04-20-83$ & & $8.5 \pm 1.2$ & $0.91 \pm 0.07$ \\
\hline 6 & $04-20-83$ & & $7.8 \pm 2.0$ & $0.92 \pm 0.05$ \\
\hline 7 & $05-04-83$ & & $13.4 \pm 3.2$ & $0.82 \pm 0.04$ \\
\hline 8 & $05-24-83$ & & $10.8 \pm 3.2$ & $0.82 \pm 0.05$ \\
\hline
\end{tabular}

Table 6. Mean \pm standard deviation of gill $\mathrm{Na}+\mathrm{K}+$ ATPase activities and condition factor values. The group 4 (05-19-83) sample contained 60 individuals, all others are 30 fish samples. 


\begin{tabular}{ccc} 
Group No. & No. of +1 samples & Percentage of +1 samples \\
\hline 1 & $3 / 30$ & 10.0 \\
2 & $4 / 30$ & 13.3 \\
3 & $3 / 30$ & 10.0 \\
4 & $8 / 60$ & 13.3 \\
5 & $5 / 30$ & 16.7 \\
6 & $4 / 30$ & 13.3 \\
7 & $4 / 30$ & 13.3 \\
8 & $2 / 30$ & 6.7 \\
\hline
\end{tabular}

Tabie 7. The number and percentage of fish in each group infected with R. salmoninamu. 
observed in any fish. The status of each individual is presented in Appendix B.

\section{Histological Examination}

The histological examination of gills, nasal epithelium, livers, and kidney tissues revealed several abnormalities. Gills collected from the majority of smolts in late April-early May (groups 1, 2, 5, 6, and 7) exhibited considerable hypertrophy of lamellar epithelium. Scattered fusion of some gill lamallae was observed but was considered to be mild. Gills from smolts in groups 3,4 , and 8 appeared to be in extremely good condition.

A similar occurrence was observed in the nasal epithelium. Considerable edema and mild diffuse necrosis of nasal sensory epithelial cells were found in a large percentage of fish in groups $1,2,5,6$, and 7 . The nasal epithelium examined from smolts in groups 3,4 , and 8 appeared in good condition with only occasional focal areas of edema.

Liver tissue and kidneys from all groups were essentially normal. Some mild swelling of kidney tubule epithelium was observed but only occasionally.

The complete histological report and micrographs submitted by Mr. C. Smith are contained in Appendix $D$.

\section{Gross Examination}

A minimum of 30 fish from each group were examined at each sampling date. Pre-marking exams showed that the fish were in good health. Light parasite loads of Gyrodactylus, Epistyl is and Ichthyopthirius and light-to-moderate dorsal erosion were noted.

Examinations in March revealed similar parasite loads and increased dorsal fin erosion. Light gill swelling and extension of some filaments beyond the 
opercles became apparent at this time. Some short rod bacteria and debris were found in the gilis. Fish health remained good. In late March, gill swelling and moderate-heavy dorsal fin erosion persisted.

During April, fin erosion and gill swelling were reduced. By mid-April fish were reported to be in very good condition. All groups of fish had attained smolt morphological characteristics by this time. All fish maintained at the hatchery during the remainder of the rearing period were found to be of high quality.

Fish release prior to 05/03/83 (groups $1,2,3,5,6$, and 7) exhibited more gill swelling and dorsal erosion than those released later in May (groups 4 and 8). However, fish health in the early release groups did not appear to be impaired. No viral or bacterial infections occurred during the sampling period.

Appendix $C$ contains a summary of the pre-release fish exams by Joseph $C$. Lientz (Division 3 Fish Disease Biologist). 
DISCUSSION

The data indicate that the fish were in various degrees of health. The mean plasma Na+ concentration of each group is within the normal expected range. The increase in plasma $\mathrm{Na}+$ concentrations observed on $03 / 17 / 83$ in group 4 is indicative of smoltification in steelhead trout at DNFH (Bradley and Rourke, 1983). It is not possible to say that all the groups went through this change due to the single sample point. However, the plasma $\mathrm{Na}$ + concentrations of the other groups at release are similar to those in group 4.

The low plasma $\mathrm{K}+$ concentrations in several smolts indicate a slight problem with ionic balance. It is normal to have a small number of individuals with low plasma $\mathrm{K}+$ in a population but groups $1,3,5$, and 6 have an excessive number.

Gill Na+/K+ ATPase activities increased and condition factor values decreased as would be expected in fish undergoing smoltification. The cause of the four low Na+/K+ ATPase activities in group 2 smolts is unknown but could be the result of problems with the assay. The four high activities from group $1(04 / 20)$ may also be due to assay difficulties or simpiy fish with abnormally high activities.

The incidence of Renibacterium saimoninarum in steelhead trout smolts was higher than in previous years. The increased number of spring chinook salmon being reared at DNFH might be the cause. This increased incidence does not appear to have had any detrimental effects on the steelhead trout smolts. No lesions or abnormalities were visible by gross examination and no subclinical signs were seen during histological examination. Fish health problems from $R$. salmoninarum may occur in steelhead trout at DNFH in the future but as of this time no effects have been seen.

Histological examinations revealed that smolts released in late April early May (groups 1, 2, 5, 6, and 7) exhibited several abnormalities, 
particularly epithelial hypertrophy and edema in gill and nasal-tissues. Fish released later in May (groups 3, 4, and 8) had much fewer anomalies. A possible cause for this phenomenon might be related to the high level of environmental solids in late March - early. April. Prior to the switch from reused water to single-pass water on $04 / 07 / 83$, the environmental solids reached maximum levels for the year. The elevated solids concentration may have caused the observed gill and nasal epithelium damage. The decreased solids during raw water rearing might allow recovery of tissues damaged by solids. The longer recovery time before sampling of group 3, 4, and 8 could explain the better conditions of gill and nasal epithelium in fish of these groups.

In summary it can be concluded that the fish in all groups were in good health and well advanced in smoltification. The major difference between groups is the higher incidence of gill and nasal epithelial hyperplasia in groups $1,2,5,6$, and 7 . It might be worthwhile to consider this when examining adult returns. 


\section{REFERENCES}

Bradley, T. and A. Rourke. 1983. Changes in plasma protein synthesis and electrolyte concentrations during smoltification in steelhead trout (Salmo gairdneri). Manuscript in preparation.

Bullock, G. L. and H. M. Stuckey, 1975. Fluorescent antibody identification and detection of the Corynebacterium. causing kidney disease of salmonids. J. Fish. Res. Bd. Can. 32(11):2224-2227.

Zaugg, W. S. 1982. Some changes in smoltification and seawater adaptability of salmonids resulting from environmental and other factors. Aquacuiture 28:143-151. 


\section{APPENOIX A}

Individual values and mean \pm standard deviation for the weight, length, $K$ factor, hematocrit (Hct), plasma $\mathrm{Na}+$ and $\mathrm{K}+$ concentrations, and gill $\mathrm{Na} / \mathrm{K}+$ ATPase activity of all fish sampled. 
Group 1 Pond 28 04-20-83

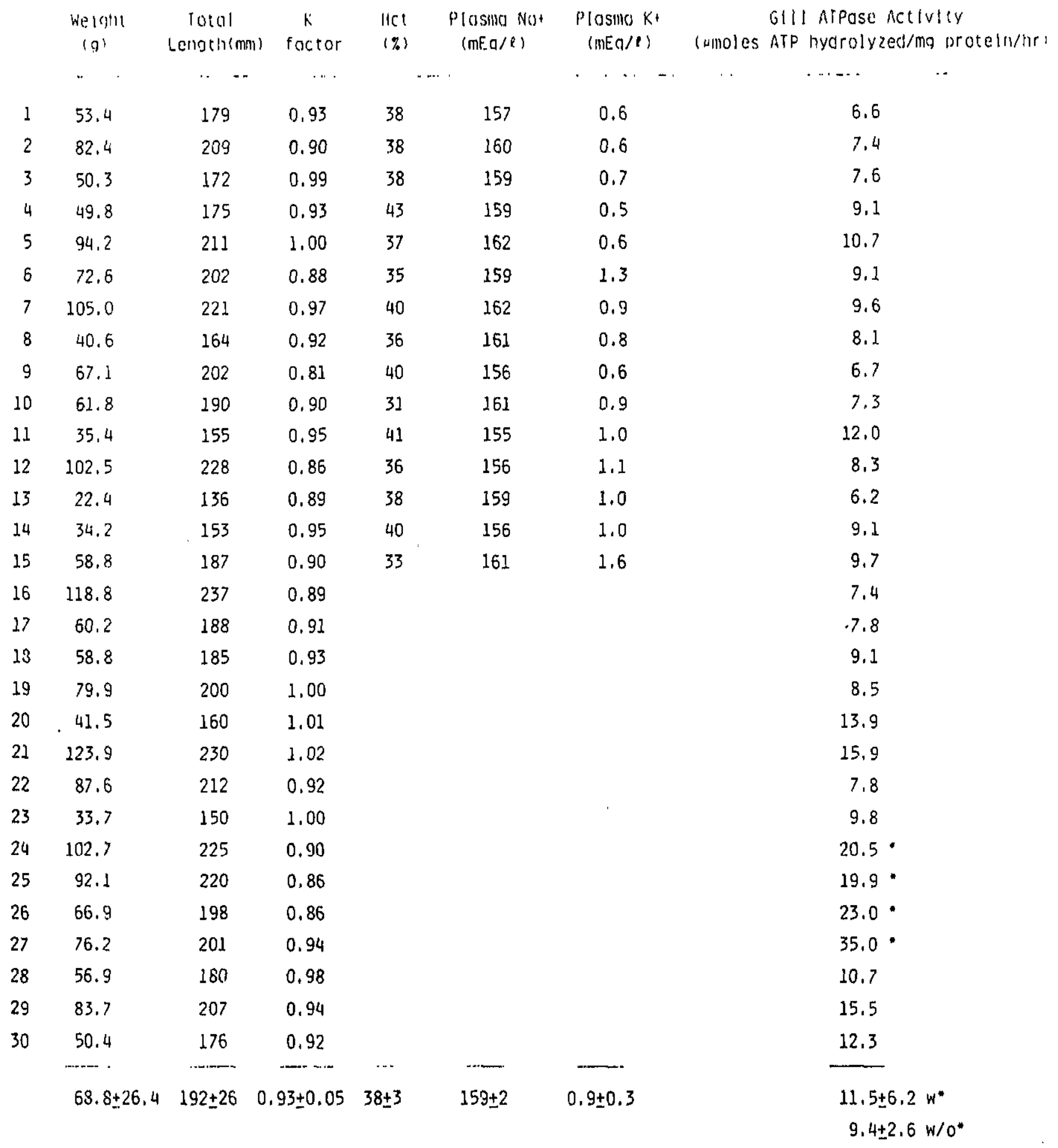


Group 2 Pond 40 04-29-83

\begin{tabular}{|c|c|c|c|c|c|c|c|c|}
\hline & $\begin{array}{l}\text { He !q̣llt } \\
\text { (و) }\end{array}$ & $\begin{array}{c}\text { lotol } \\
\text { Length(m) }\end{array}$ & $\begin{array}{c}k \\
\text { foctor }\end{array}$ & $\begin{array}{l}\mathrm{HCl} \\
(\bar{z})\end{array}$ & $\begin{array}{l}\text { Plosmo No+ } \\
(\mathrm{mEa} / \mathrm{l})\end{array}$ & $\begin{array}{l}\text { Plosmo K+ } \\
\text { (mEq/e) }\end{array}$ & (umoles & $\begin{array}{l}\text { GIII ATPose ACtIv!ty } \\
\text { ATP hydrolyzed/mg proteln/hr I }\end{array}$ \\
\hline & $\cdots$ & $\cdot \cdot \cdot$ & . & & $\cdots$ & $-\cdots$ & $-\cdots$ & - \\
\hline 1 & 87.1 & 216 & 0.86 & 38 & 156 & 1.1 & & 10.0 \\
\hline 2 & 73.2 & 200 & 0.92 & 41 & .154 & 1.3 & & 5.4 \\
\hline 3 & 79.3 & 215 & 0.80 & 38 & 152 & 1.5 & & 10.2 \\
\hline 4 & 50.2 & 176 & 0.92 & 41 & 155 & 1.2 & & 11.1 \\
\hline 5 & 128.0 & 233 & 1.01 & 32 & 153 & 1.7 & & 7.4 \\
\hline 6 & 97.8 & 225 & 0.86 & 38 & 155 & 1,8 & & $2.7 \cdot$ \\
\hline 7 & 101.0 & 227 & 0.86 & 40 & 157 & 1.6 & & $3.8^{\circ}$ \\
\hline 8 & 84.4 & 219 & 0.80 & 36 & 153 & 1.7 & & 0.1. \\
\hline 9 & 56.6 & 182 & 0.94 & 33 & $150^{\prime}$ & 0.9 & & $0.4^{\circ}$ \\
\hline 10 & 95.8 & 225 & 0.84 & 40 & 153 & 0.6 & & 7.2 \\
\hline 11 & 99.3 & 229 & 0.83 & 36 & 150 & 0.9 & & $3.8^{\circ}$ \\
\hline 12 & 68.4 & 201 & 0.84 & 37 & 145 & 0.7 & & 9.7 \\
\hline 13 & 76.0 & 209 & 0.83 & 38 & 151 & 1.2 & & 9.0 \\
\hline 14 & 86.7 & 218 & 0.84 & 41 & 152 & 0.9 & & 14.2 \\
\hline 15 & 46.5 & 174 & 0.88 & & 152 & 1.0 & & 12.7 \\
\hline 16 & 85.5 & 218 & 0.83 & 37 & 151 & $\cdot 1.2$ & & 9.6 \\
\hline 17 & 74.2 & 208 & 0.82 & & & & & 9.7 \\
\hline 13 & 67.8 & 199 & 0.86 & & & & & 8.0 \\
\hline 19 & 88.5 & 219 & 0.84 & & & & & 8.3 \\
\hline 20 & 72.8 & 202 & 0.88 & & & & & 11.2 \\
\hline 21 & 50.0 & 177 & 0.90 & & & & & 10.9 \\
\hline 22 & 39.8 & 154 & 1.09 & & & & & 8.8 \\
\hline 23 & 81.2 & 209 & 0.89 & & & & & 8.3 \\
\hline 24 & 67.9 & 200 & 0.85 & & & & & 9.3 \\
\hline 25 & 70.5 & 193 & 0.98 & & & & & 10.2 \\
\hline$\cdot-26$ & 79.3 & 207 & 0.89 & & & & & 10.5 \\
\hline 27 & 69.2 & 196 & 0.92 & & & & & 9.1 \\
\hline 28 & 36.6 & 160 & 0.89 & & & & & 5.8 \\
\hline 29 & 102.2 & 216 & 1.01 & & & & & 7.1 \\
\hline \multirow[t]{3}{*}{30} & $\begin{array}{l}114.2 \\
\ldots \ldots . .\end{array}$ & $\begin{array}{r}235 \\
-\end{array}$ & $\begin{array}{r}0.88 \\
\end{array}$ & $-\longrightarrow$ & $\ldots$ & - & & 8.4 \\
\hline & $77.7 \pm 21.3$ & $205 \pm 21$ & $0.89 \pm 0.07$ & $38 \pm 1$ & $152 \pm 1$ & $1,2 \pm 0,1$ & & $9.3 \pm 2.0 \mathrm{~W} / 0^{\circ}$ \\
\hline & & & & & & & & $8.1 \pm 3.3 \mathrm{w}^{\circ}$ \\
\hline
\end{tabular}


Group 3 Pond 36 05-02-83

\begin{tabular}{|c|c|c|c|c|c|c|c|}
\hline & $\begin{array}{l}\text { Welght } \\
(g)\end{array}$ & $\begin{array}{l}\text { Total } \\
\text { Length(m) }\end{array}$ & $\begin{array}{c}k \\
\text { foctor }\end{array}$ & $\begin{array}{l}\text { HCt } \\
(x)\end{array}$ & $\begin{array}{l}\text { Plasma } \mathrm{Na}^{+} \\
(\mathrm{mEa} / \ell)\end{array}$ & $\begin{array}{l}\text { Plasma K+ } \\
(\mathrm{mEq} / \mathrm{l})\end{array}$ & $\begin{array}{l}\text { Glll ATPose Activlty } \\
\text { (umoles ATP hydrolyzed/mg proteln/hr }\end{array}$ \\
\hline & $\cdots-$ & $\cdots \cdot-\cdots$ & $-\cdots$ & -7 & - & $-\cdots$ & . \\
\hline 1 & 62.3 & 193 & 0.87 & 37 & 155 & 0.9 & 9.8 \\
\hline 2 & 98.6 & 229 & 0.82 & 37 & 154 & 0.4 & 7.2 \\
\hline 3 & 66.2 & 193 & 0.92 & 33 & 153 & 0.9 & 15.9 \\
\hline 4 & 70.7 & 208 & 0.79 & 36 & 153 & 0.5 & 17.4 \\
\hline 5 & 104.8 & 230 & 0.86 & 37 & 145 & 0.4 & 18.0 \\
\hline 6 & 53.5 & 187 & 0.82 & 39 & 155 & 0.8 & 9.6 \\
\hline 7 & 54.2 & 186 & 0.84 & 39 & 157 & 0.6 & 7.3 \\
\hline 8 & 71.2 & 205 & 0.83 & 38 & 156 & 0.9 & 17.1 \\
\hline 9 & 52.6 & 181 & 0.89 & 35 & 152 & 0.8 & 14.3 \\
\hline 10 & 61.6 & 190 & 0.90 & 39 & 156 & 0.3 & 10.9 \\
\hline 11 & 83.7 & 219 & 0.80 & 38 & 152 & 0.5 & 16.6 \\
\hline 12 & 86.5 & 219 & 0.82 & 41 & 157 & 0.8 & 12.8 \\
\hline 13 & 62.3 & 192 & 0.88 & 45 & 152 & 0.6 & 12.5 \\
\hline 14 & 70.7 & 207 & 0.80 & & 152 & 1,1 & 9.7 \\
\hline 15 & 78.1 & 203 & 0.93 & 31 & 146 & 1.4 & 12.4 \\
\hline 16 & 126.2 & 246 & 0.85 & & & & 9.5 \\
\hline 17 & 53.3 & 186 & 0.83 & & & & 20.5 \\
\hline 13 & 87.8 & 216 & 0.87 & & & & 17.1 \\
\hline 19 & 71.9 & 201 & 0.89 & & & & 13,2 \\
\hline 20 & 89.7 & 219 & 0.85 & & & & 18.6 \\
\hline 21 & 69.2 & 199 & 0.88 & & & & 16.0 \\
\hline 22 & 91.5 & 218 & 0.88 & & & & 8.6 \\
\hline 23 & 92.6 & 222 & 0.85 & & & & 10.7 \\
\hline 24 & 53.1 & 184 & 0.85 & & & & 10.9 \\
\hline 25 & 73.9 & 206 & 0.85 & & & & 13.8 \\
\hline 26 & 96,5 & 229 & 0.80 & & & & 16.1 \\
\hline 27 & 63.6 & 192 & 0.90 & & & & 12.3 \\
\hline 28 & 62.5 & 193 & 0.87 & & & & 10.3 \\
\hline 29 & 52.8 & 184 & 0.85 & & & & 10.0 \\
\hline 30 & 81.1 & 212 & 0.85 & & & & 12.7 \\
\hline & $74.7+18$ & $205+17$ & $85+0.04$ & $37+3$ & $153 \pm 3$ & $0.7 \pm 0.3$ & $13.1 \pm 3.6$ \\
\hline
\end{tabular}


Group $4-1$ Pond 34 03-01-83

Welght Total $K$ HCt Plosma Na+ Plosmo K+ Glll ATPase Activlty (g) Length(m) foctor (z) (mEq/l) (mEa/l) (umoles ATP nydrolyzed/mg oroteln/hr)

\begin{tabular}{|c|c|c|c|c|c|c|c|}
\hline 1 & 50.1 & 176 & 0.92 & 38 & 160 & 1.4 & 7,4 \\
\hline 2 & 92,0 & 210 & 0.99 & 38 & 161 & 1,5 & 5.5 \\
\hline 3 & 68.8 & 192 & 0.97 & 32 & 161 & 1.2 & 4.7 \\
\hline 4 & 56.5 & 180 & 0.97 & 39 & 156 & 1.2 & 4.2 \\
\hline 5 & 50,3 & 173 & 0.97 & & 165 & 1,5 & 5.0 \\
\hline 6 & 51.2 & 175 & 0.96 & 39 & 155 & 1,3 & 5.5 \\
\hline 7 & 57.6 & 184 & 0,92 & 39 & 154 & 1,5 & 5,2 \\
\hline 8 & 59.9 & 181 & 1.01 & 391 & 157 & 1.8 & 4,8 \\
\hline 9 & 75.6 & 200 & 0.95 & 39 & 159 & 1.4 & 5,1 \\
\hline 10 & 67.2 & 189 & 1.00 & 45 & 162 & 0.8 & 5.1 \\
\hline 11 & 82.8 & 204 & 0.97 & 40 & 161 & 1.3 & 5.3 \\
\hline 12 & 64,0 & 184 & 1.03 & 44 & 152 & 0.7 & 5,8 \\
\hline 13 & 32.4 & 150 & 0.96 & 33 & 156 & 1.8 & 6.8 \\
\hline 14 & 27.5 & 141 & 0.98 & 35 & 154 & 2.5 & 8.0 \\
\hline 15 & 63.0 & 188 & 0.95 & 39 & 164 & 1,5 & 6.7 \\
\hline 16 & 51.9 & 167 & 1.11 & 40 & 157 & 1,3 & 5.9 \\
\hline 17 & 58.9 & 185 & 0.93 & & & & 5.7 \\
\hline 13 & 29.7 & 143 & 1,02 & & & & 7.0 \\
\hline 19 & 91.9 & 211 & 0.98 & & & & 5,4 \\
\hline 20 & 63.7 & 190 & 0.93 & & & & 7.0 \\
\hline 21 & 59.3 & 184 & 0.95 & & & & 8.7 \\
\hline 22 & 72.8 & 197 & 0.95 & & & & 4,8 \\
\hline 23 & 57.7 & 178 & 1.02 & & & & 4,8 \\
\hline 24 & 49,9 & 171 & 1.00 & & & & 5.6 \\
\hline 25 & 56.8 & 176 & 1.04 & & & & 4.9 \\
\hline 26 & 66.9 & 189 & 0.99 & & & & 3.6 \\
\hline 27 & 55.4 & 179 & 0.97 & & & & 4,5 \\
\hline 28 & 64.2 & 183 & 1.05 & & & & 4,1 \\
\hline 29 & 63.3 & 184 & 1,02 & & & & 4,8 \\
\hline 30 & 63.9 & 194 & 0,88 & & & & 4.8 \\
\hline & $0.2 ! 14, ?$ & $2 \pm 10$ & $8 \pm 0.05$ & $39 \pm 3$ & $158 \pm 4$ & $1.4 \pm 0.4$ & $5,0 \pm 1,2$ \\
\hline
\end{tabular}


Group 4-2 Pond 34 03-17-83

\begin{tabular}{|c|c|c|c|c|c|c|c|}
\hline & $\begin{array}{l}\text { Weight } \\
(0)\end{array}$ & $\begin{array}{l}\text { Total } \\
\text { Length(mm) }\end{array}$ & $\begin{array}{c}k \\
\text { foctor }\end{array}$ & $\begin{array}{l}\text { Hct } \\
(x)\end{array}$ & $\begin{array}{l}\text { Plosmo No+ } \\
(m E Q / t)\end{array}$ & $\begin{array}{l}\text { Plasma K+ } \\
\text { (mEQ/l) }\end{array}$ & $\begin{array}{c}\text { GIll ATPase Activity } \\
\text { (umoles ATP hydrolyzed/mg proteln } / \mathrm{hr}\end{array}$ \\
\hline 1 & 61.2 & 184 & 0,98 & 34 & 168 & 2.5 & 4.4 \\
\hline 2 & 47.0 & 167 & 1.01 & 26 & 168 & 2.2 & 5,8 \\
\hline 3 & 66.4 & 208 & 0.74 & 30 & 180 & 2.6 & 6.0 \\
\hline 4 & 51.7 & 175 & 0.96 & 28 & 181 & 2.3 & 6.2 \\
\hline 5 & 58.2 & 182 & 0.97 & 28 & 157 & 2.4 & 8.8 \\
\hline 6 & 59.0 & 185 & 0.93 & 32 & 165 & 2,3 & 6.3 \\
\hline 7 & 87.8 & 208 & 0,98 & 32 & 177 & 2,3 & 7.7 \\
\hline 8 & 22.2 & 133 & 0.94 & 33 & 169 & 2.5 & 5.2 \\
\hline 9 & 71.5 & 201 & 0.88 & 29 & 159 & 1.2 & 5.7 \\
\hline 10 & 89.4 & 212 & 0.94 & 41 & 166 & 1.1 & 4,5 \\
\hline 11 & 61.2 & 192 & 0.86 & 33 & 159 & 1,3 & 4,4 \\
\hline 12 & 75.6 & 201 & 0,93 & 38 & 153 & 1.0 & 5.0 \\
\hline 13 & 90.2 & 208 & 1.00 & 36 & 171 & 1.8 & 5.7 \\
\hline 14 & 30.9 & 149 & 0.93 & 32 & 165 & 2.2 & 5.4 \\
\hline 15 & 59,4 & 184 & 0.95 & 32 & 167 & 2.0 & 5.9 \\
\hline 16 & 42.9 & 164 & 0.97 & 32 & 160 & 2.0 & 4.9 \\
\hline 17 & 33.1 & 152 & 0.94 & & & & 4.5 \\
\hline 13 & 62.1 & 188 & 0.93 & & & & 4.9 \\
\hline 19 & 97,2 & 216 & 0,96 & & & & 4.0 \\
\hline 20 & 50.9 & 172 & 2,00 & & & & 5.2 \\
\hline 21 & 55.2 & 175 & 1.03 & & & & 5.5 \\
\hline 22 & 56.5 & 175 & 1.05 & & & & 5.2 \\
\hline 23 & 72.0 & 194 & 0.99 & & & & 4.8 \\
\hline 24 & 54,2 & 174 & 1.03 & & & & 5.5 \\
\hline 25 & 70.9 & 196 & 0.94 & & & & 5.4 \\
\hline 26 & 73.4 & 189 & 1.09 & & & & 5.7 \\
\hline 27 & 68.4 & 194 & 0,94 & & & & 4.7 \\
\hline 28 & 61.9 & 182 & 1.03 & & & & 5.8 \\
\hline 29 & 73.3 & 195 & 0,99 & & & & 6.3 \\
\hline 30 & 49.7 & 178 & 0.88 & & & & 5.5 \\
\hline & $61,8 \pm 17,4$ & $184 \pm 19 \quad 0$. & $96 \pm 0.07$ & $32+4$ & $167 \pm 2$ & $2,0 \pm 0.1$ & $5,5 \pm 1.0$ \\
\hline
\end{tabular}




\section{Group $4-3$ Pond $34 \quad 03-31-83$}

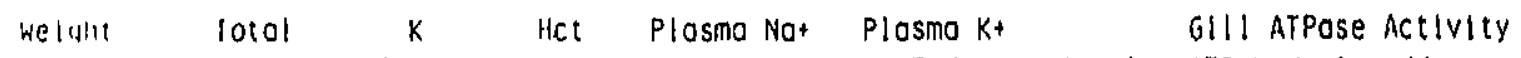
(g) Length(m) foctor ( $\mathrm{g}$ ) (mEa/l) (mEa/l) (umoles ATP hydrolyzed/mg proteln/hr)

$\begin{array}{rrrrrrr}67.2 & 192 & 0.95 & 33 & 171 & 1.9 & 10.5 \\ 118.2 & 232 & 0.95 & 37 & 168 & 1.4 & 10.1 \\ 54.3 & 179 & 0.95 & 35 & 163 & 1.8 & 6.7 \\ 80.1 & 205 & 0.93 & 32 & 162 & 1.3 & 8.5 \\ 113.4 & 233 & 0.90 & 38 & 171 & 2.3 & 7.0 \\ 82.5 & 211 & 0.88 & 30 & 165 & 2.2 & 10.7 \\ 57.4 & 184 & 0.92 & 35 & 165 & 1.7 & 5.0\end{array}$

757.4

84

0.92

165

1.7

5.0

55.3

186

0.86

30

1.9

6.3

84.8

0.93

0.5

6.1

60.4

184

0.97

40

161

0.5

5.1

$11 \quad 78.8 \quad 201$

0.97

35

161

0.9

6.4

$12 \quad 75.2 \quad 200$

0.94

37

162

0.6

6.8

1365.

189

0.97

37

1.1

5.4

60.4

187

0.92

41

162

0.9

5.6

1563.7

193

0.89

36

165

1.1

6.8

16

44.5

173

0.86

35

159

1.0

6.8

$174 \quad 0.96$

6.5

13

$26.9 \quad 140 \quad 0.98$

5.2

19

68.5

193

0.95

4.4

$41.6 \quad 164$

0.94

5.8

82.2

209

0.90

8,2

91.9

221

0.85

5.9

88.2

210

0.95

4.7

73.7

196

0.98

8,1

59.8

189

0.89

6,3

54.0

174

1.03

6.7

65.8

194

0.90

8.0

57.1

184

0.92

9.5

92.4

217

0.90

6.7

47.1

166

1.03

6.6

$68.7 \pm 20.2 \quad 193 \pm 20$

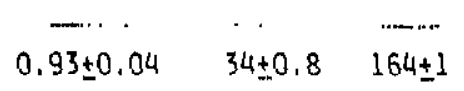

$1.3 \pm 0.2$

$6.9 \pm 1.7$ 
Group $4-4$ Pond $34 \quad 04-14-83$

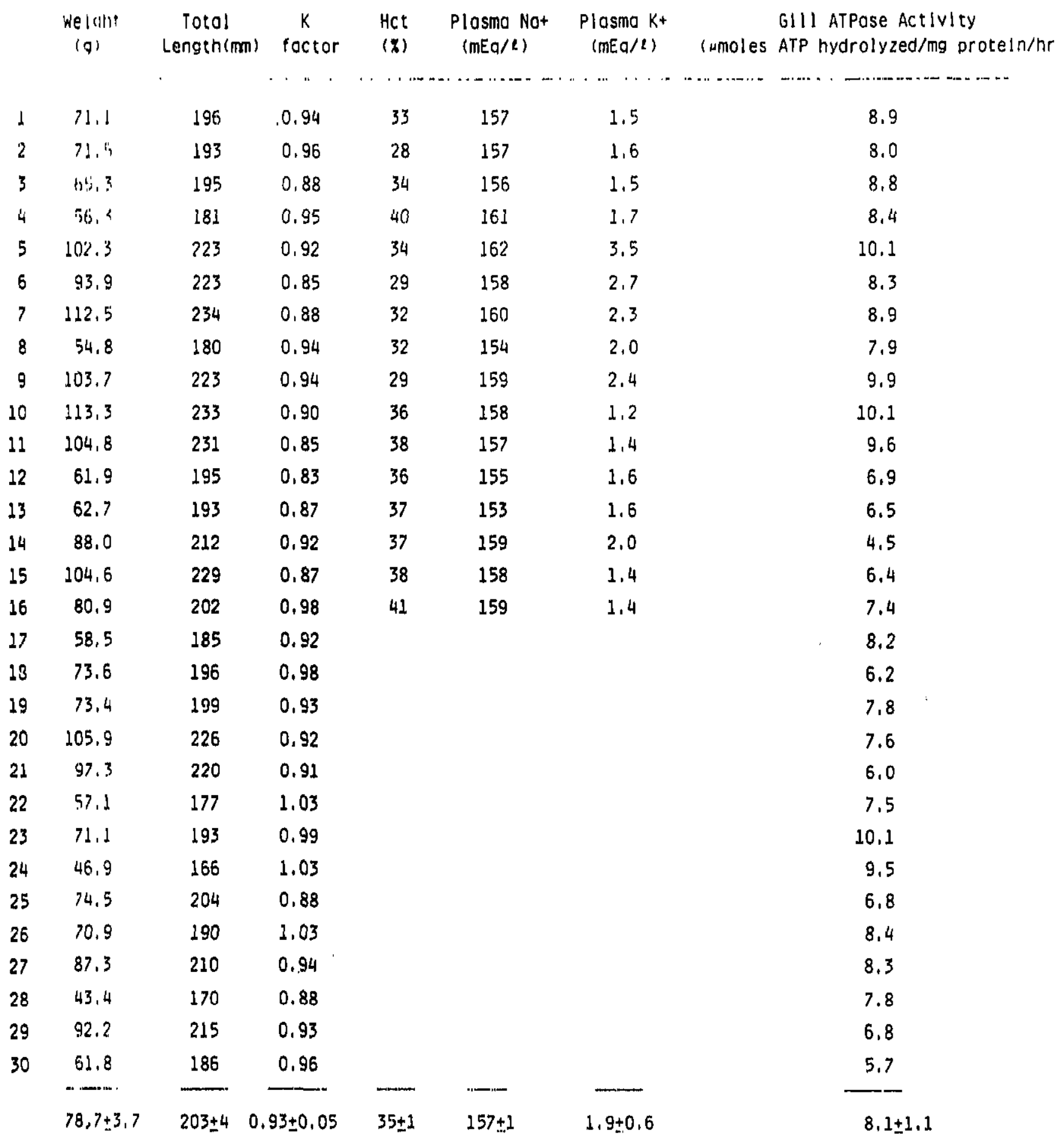


Group $4-5$ Pond 34 04-19-83

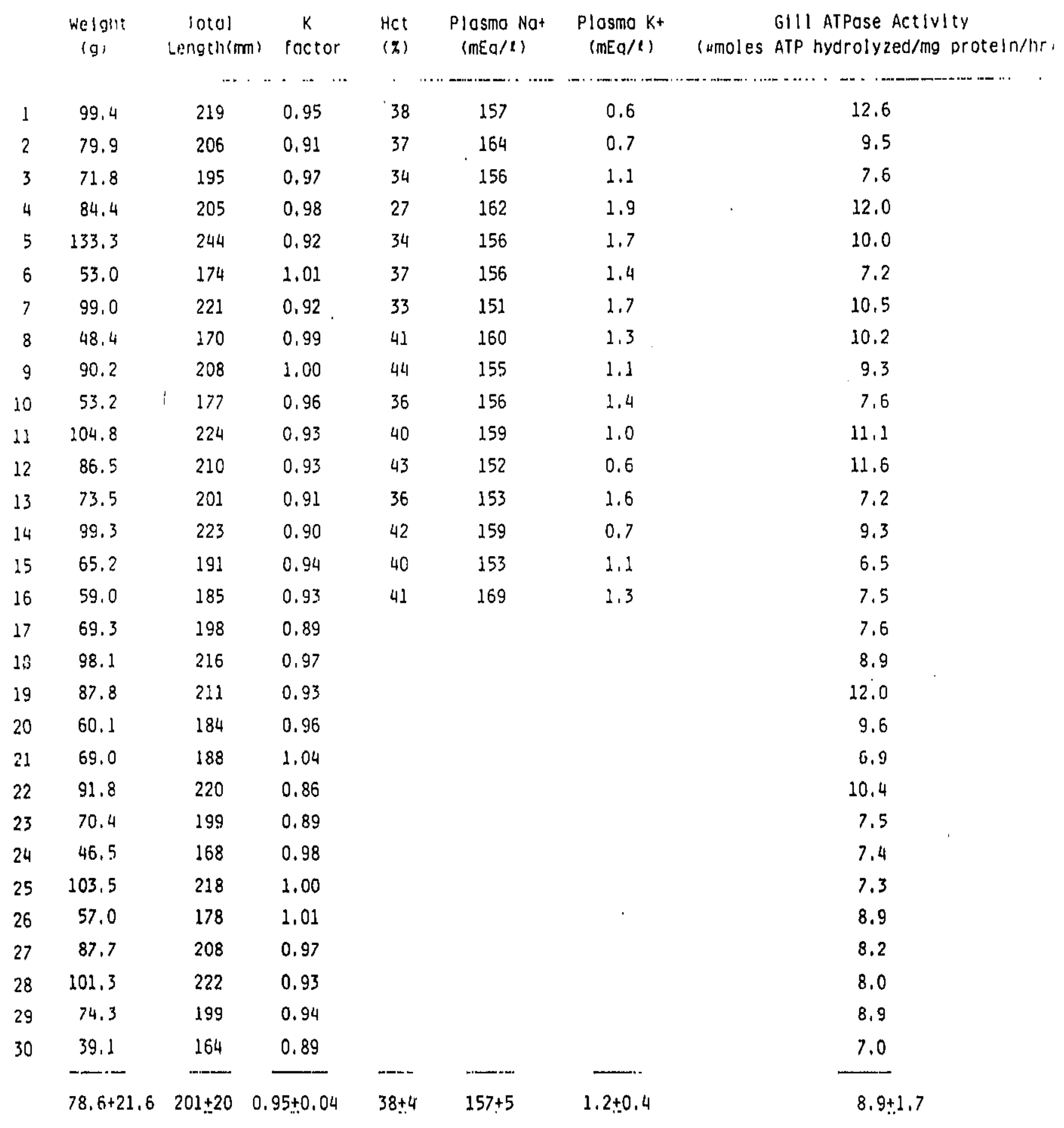


Group 4-6 Pond 34 05-05-83

\begin{tabular}{|c|c|c|c|c|c|c|c|c|}
\hline & $\begin{array}{l}\text { Welght } \\
\text { "; }\end{array}$ & $\begin{array}{l}\text { Totol } \\
\text { Length(rm) }\end{array}$ & $\begin{array}{c}k \\
\text { factor }\end{array}$ & $\begin{array}{l}\text { HCt } \\
(z)\end{array}$ & $\begin{array}{l}\text { Plosmo No+ } \\
(\mathrm{mEq} / \ell)\end{array}$ & $\begin{array}{l}\text { Plasmo } K_{+}+ \\
\text {(mEg/R) }\end{array}$ & (umoles & $\begin{array}{l}\text { G111 ATPase Activlty } \\
\text { ATP hydrolyzed/mg proteln } / \text { hr I }\end{array}$ \\
\hline & & $\cdots$ & . . & $\cdots$ & & ... & . & $\cdots \cdot$ \\
\hline 1 & 72,3 & 204 & 0.85 & 36 & 160 & 1.8 & & 16.0 \\
\hline 2 & 72.1 & 206 & 0.82 & 34 & 160 & 1.6 & & 10.1 \\
\hline 3 & 68.9 & 201 & 0.85 & 32 & 151 & 1.3 & & 10.0 \\
\hline 4 & 53.6 & 182 & 0.89 & 39 & 157 & 1.4 & & 21.5 \\
\hline 5 & 78.4 & 204 & 0.92 & 38 & 163 & 1.9 & & 12.5 \\
\hline 6 & 93.1 & 216 & 0.92 & 38 & 161 & 1.6 & & 14.2 \\
\hline 7 & 73.9 & 210 & 0.80 & 39 & 159 & 1.6 & & 18.3 \\
\hline 8 & 74.8 & 205 & 0.87 & 33 & 156 & 2.3 & & 9.5 \\
\hline 9 & 106.3 & 225 & 0.93 & 35 & 160 & 1.7 & & 13.5 \\
\hline 10 & 57.1 & 187 & 0.87 & 31 & 160 & 2.2 & & 9.1 \\
\hline 11 & 55.5 & 180 & 0.95 & 33 & 163 & 1.6 & & 9.5 \\
\hline 12 & 76.2 & 210 & 0.82 & 37 & 156 & 1.7 & & 18.4 \\
\hline 13 & 75.0 & 206 & 0.86 & 34 & 153 & 2.0 & & 8.2 \\
\hline 14 & 69.2 & 199 & 0.88 & 34 & 160 & 1.9 & & 9.9 \\
\hline 15 & 72.2 & 197 & 0.94 & 44 & 160 & 1.3 & & 9.7 \\
\hline 16 & 54.2 & 179 & 0.94 & 32 & 149 & 2.3 & & 7.9 \\
\hline 17 & 54,4 & 187 & 0.83 & & & & & 14.6 \\
\hline 13 & 79.7 & 206 & 0.91 & & & & & 9.3 \\
\hline 19 & 82.1 & 209 & 0.90 & & & & & 20.4 \\
\hline 20 & 79.9 & 208 & 0.89 & & & & & 18.6 \\
\hline 21 & 76.1 & 203 & 0.91 & & & & & 20.3 \\
\hline 22 & 91.7 & 211 & 0.98 & & & & & 9.0 \\
\hline 23 & 81.9 & 203 & 0.98 & & & & & 12.0 \\
\hline 24 & 118.0 & 228 & 1.00 & & & & & 17.4 \\
\hline 25 & 121.0 & 234 & 0.94 & & & & & 14.1 \\
\hline 26 & 77.7 & 203 & 0.93 & & & & & 23.8 \\
\hline 27 & 84.4 & 215 & 0.85 & & & & & 9.6 \\
\hline 28 & 84.4 & 214 & 0.86 & & & & & 8.8 \\
\hline 29 & 84.2 & 210 & 0.91 & & & & & 8.1 \\
\hline 30 & $\begin{array}{r}59.1 \\
\ldots\end{array}$ & 186. & 0.92 & $\ldots$ & - & 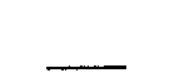 & & 18.7 \\
\hline & $77,6 \pm 16,8$ & $204 \pm 13 \quad 0$ & $90 \pm 0.05$ & $35 \pm 3$ & $158 \pm 4$ & $1,8 \pm 0,3$ & & $13.2 \pm 4.7$ \\
\hline
\end{tabular}


Group 4-7 Pond 34 05-19-83

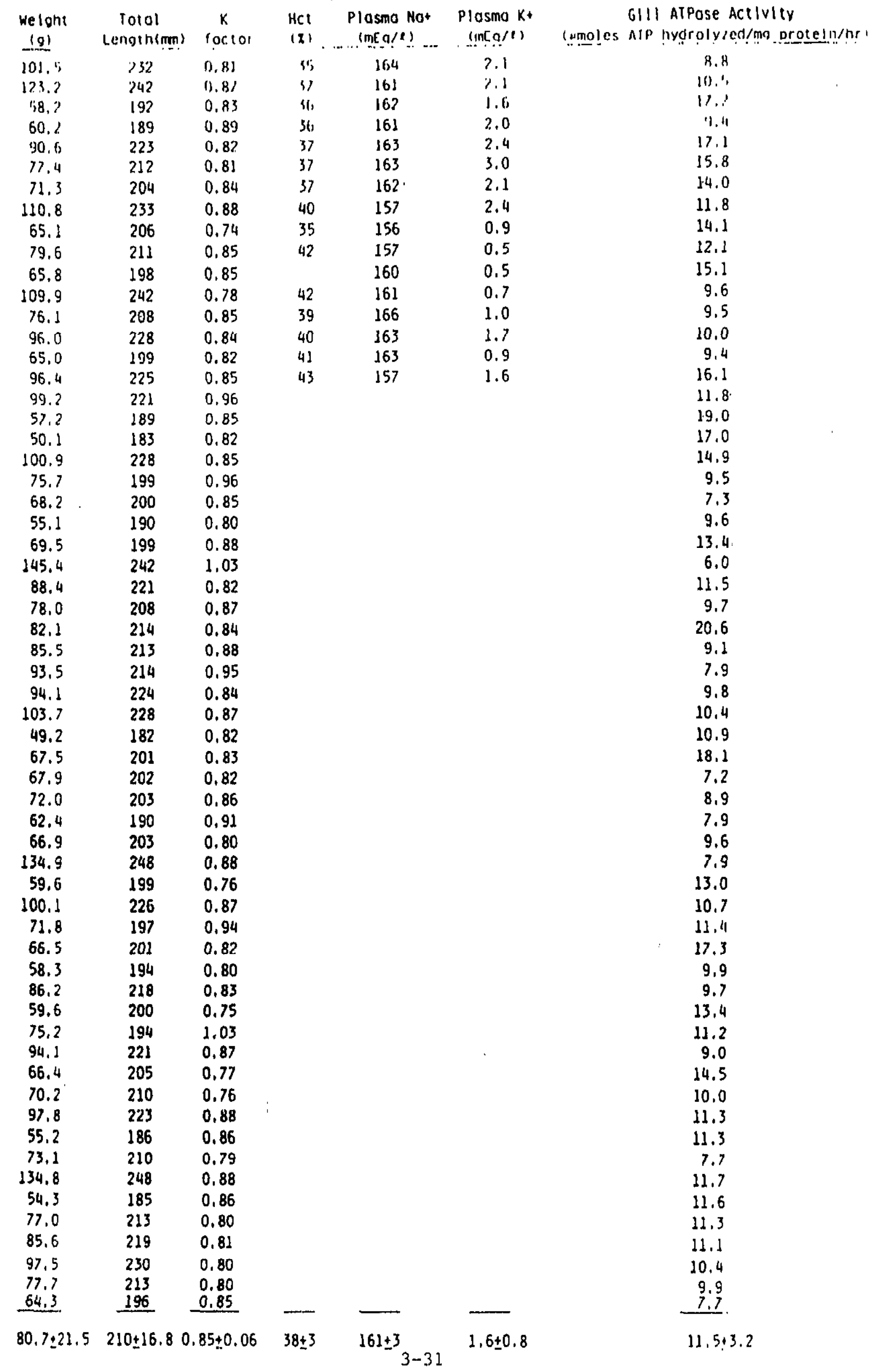


Group 5 Pond 30 04-20-83

\begin{tabular}{|c|c|c|c|c|c|c|c|}
\hline & $\begin{array}{l}\text { Weioht } \\
\text { (o) }\end{array}$ & $\begin{array}{l}\text { Total } \\
\text { L.ength(mm) }\end{array}$ & $\begin{array}{c}k \\
\text { foctor }\end{array}$ & $\begin{array}{l}\text { HCt } \\
(\%)\end{array}$ & $\begin{array}{l}\text { Plasmo Na+ } \\
\text { (mEa/f) }\end{array}$ & $\begin{array}{l}\text { Plosma K+ } \\
\text { (mEa/t) }\end{array}$ & $\begin{array}{l}\text { GIll ATPose ACtivlty } \\
\text { (umoles ATP hydrolyzed/mg proteln/hr }\end{array}$ \\
\hline & $\begin{array}{ll}\cdots \cdots \\
124.7\end{array}$ & 239 & 0.91 & $\cdots$ & 159 & 0.3 & 8.9 \\
\hline 2 & 104.8 & 234 & 0.82 & 43 & 161 & 0.4 & 7.3 \\
\hline 3 & 65.2 & 193 & 0.91 & 46 & 156 & 0.3 & 9.0 \\
\hline 4 & 79.9 & 212 & 0.84 & 35 & 156 & 0.5 & 9.2 \\
\hline 5 & 86.5 & 214 & 0.88 & 42 & 157 & 0.3 & 7.7 \\
\hline 6 & 38.5 & 158 & 0.98 & 36 & 158 & 1.1 & 8.0 \\
\hline 7 & 135.6 & 247 & 0.90 & 29 & 148 & 1.7 & 11.4 \\
\hline 8 & 63.8 & 195 & 0.86 & 37 & 160 & 0.7 & 8.9 \\
\hline 9 & 59.8 & 184 & 0,96 & 35 & 159 & 0.6 & \\
\hline 10 & 35.0 & 152 & 1.00 & 39 & 153 & 0.6 & ' \\
\hline 11 & 95.8 & 220 & 0.90 & 37 & 156 & 0.6 & 7.9 \\
\hline 12 & 77.8 & 211 & 0.83 & 41 & 158 & 0.7 & 9.5 \\
\hline 13 & 65.3 & 197 & 0.85 & 47 & 153 & 0.4 & 8.6 \\
\hline 14 & 71.4 & 194 & 0.98 & 37 & 153 & 1,0 & 7.6 \\
\hline 15 & 90.4 & 212 & 0.95 & 38 & 161 & 1.0 & 9.1 \\
\hline 16 & 89.4 & 213 & 0.93 & & & & 8.0 \\
\hline 17 & 68.2 & 204 & 0.80 & & & & 9.0 \\
\hline 13 & 65.3 & 197 & 0.85 & & & & 8.3 \\
\hline 19 & 87.8 & 220 & 0.82 & & & & 6.9 \\
\hline 20 & 59.9 & 178 & 1.06 & & & & 9.8 \\
\hline 21 & 32.5 & 148 & 1.00 & & & & 8.0 \\
\hline 22 & 92.1 & 218 & 0.89 & & & & 7.4 \\
\hline 23 & 71.1 & 204 & 0.84 & & & & 6.3 \\
\hline 24 & 113.4 & 228 & 0.96 & & & & 8.7 \\
\hline 25 & 98.5 & 222 & 0.90 & & & & 10.5 \\
\hline 26 & 36.9 & 156 & 0.97 & & & & 6.7 \\
\hline 27 & 60.9 & 182 & 1,01 & & & & 7.6 \\
\hline 28 & 77.7 & 209 & 0.85 & & & & 9.1 \\
\hline 29 & 62.1 & 188 & 0.93 & & & & 9.0 \\
\hline \multirow[t]{3}{*}{30} & 51.0 & 174 & 0.97 & & & & 9.9 \\
\hline & $\cdots-\ldots$ & $\square$ & $-\cdots$ & $\cdots$ & $\cdots \cdots$ & $-\cdots$ & $\cdots \cdots$ \\
\hline & $75,4 \pm 25,3$ & $200 \pm 25.50$ & $.91 \pm 0.07$ & $39 \pm 5$ & $156 \pm 4$ & $0.7 \pm 0.4$ & $8.5 \pm 1.2$ \\
\hline
\end{tabular}


Group 6 Pond 32 04-20-83

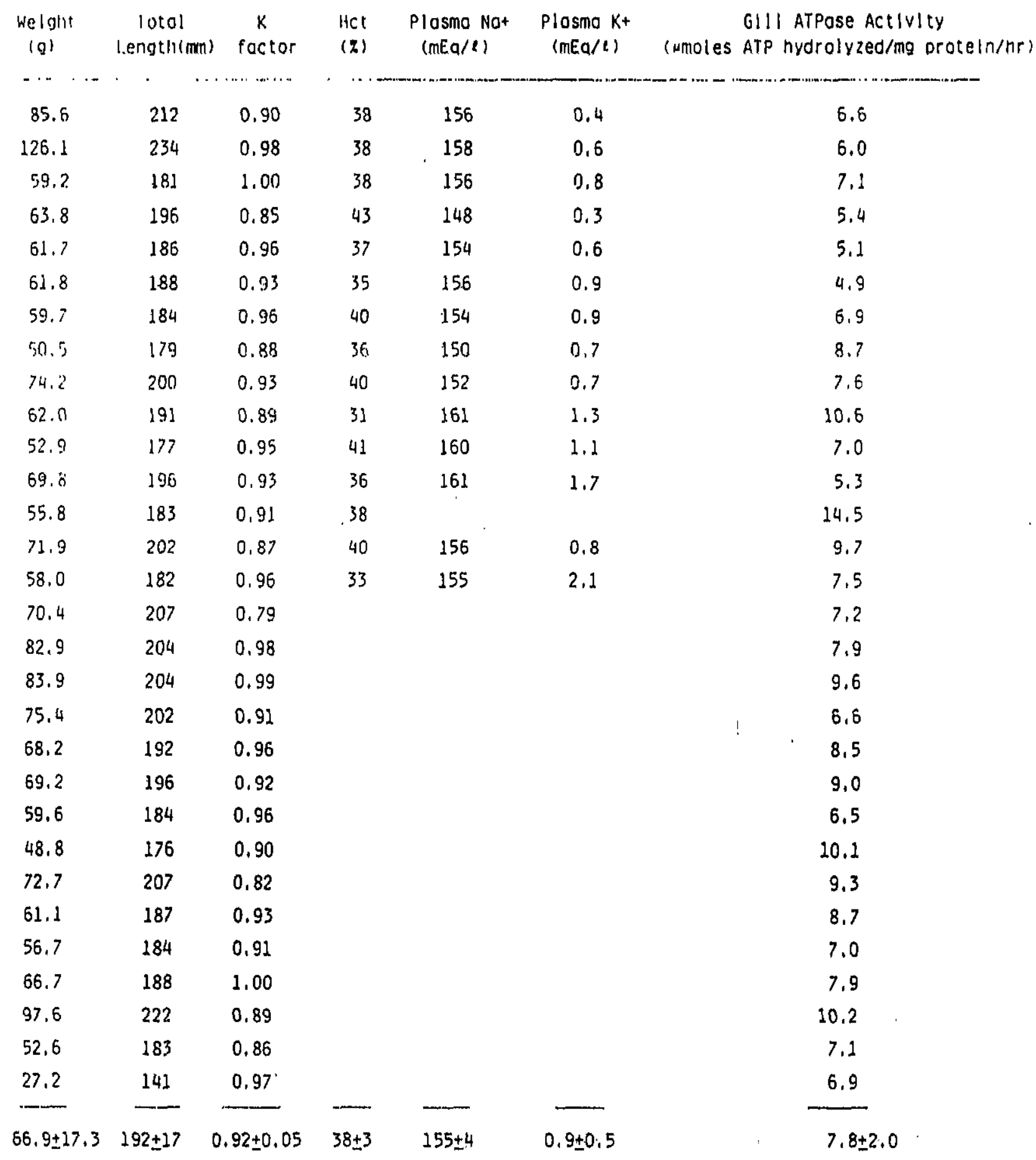




\begin{tabular}{|c|c|c|c|c|c|c|c|c|}
\hline & & & & Grou & Pond & $05-04$ & & \\
\hline & $\begin{array}{l}\text { Welght } \\
(g)\end{array}$ & $\begin{array}{l}\text { Total } \\
\text { Length(mm) }\end{array}$ & $\begin{array}{c}k \\
\text { factor }\end{array}$ & $\begin{array}{l}\text { HCt } \\
(z)\end{array}$ & $\begin{array}{l}\text { Plosma Nat } \\
(\mathrm{mEa} / \ell)\end{array}$ & $\begin{array}{l}\text { Plosma K+ } \\
(\mathrm{mEq} / \ell)\end{array}$ & (umoles & $\begin{array}{l}\text { GIll ATPOse ACtivity } \\
\text { ATP hydrolyzed/mg proteln/hr, }\end{array}$ \\
\hline 1 & 90.9 & 227 & 0.78 & 36 & 159 & 1.1 & & 11,6 \\
\hline 2 & 62,5 & 196 & 0.83 & 34 & 154 & 1.1 & & 8.3 \\
\hline 3 & 52.1 & 188 & 0.78 & 39 & 159 & 1.0 & & 19.7 \\
\hline 4 & 49.6 & 184 & 0.80 & 36 & 157 & 0.8 & & 11.4 \\
\hline 5 & 60.3 & 196 & 0.80 & 37 & 159 & 1.1 & & 20.7 \\
\hline 6 & 60.7 & 197 & 0.79 & 34 & 155 & 1.0 & & 12.3 \\
\hline 7 & 47,3 & 178 & 0.84 & 35 & 159 & 1.4 & & 14.0 \\
\hline 8 & 57.8 & 191 & 0,83 & 34 & 156 & 1,2 & & 10.4 \\
\hline 9 & 78.6 & 209 & 0,86 & 39 & 159 & 2.2 & & 13.0 \\
\hline 10 & 76.2 & 214 & 0.78 & 35 & 152 & 1.3 & & 12.3 \\
\hline 11 & 58.2 & 196 & 0.77 & 37 & 154 & 1.5 & & 12.4 \\
\hline 12 & 87,5 & 211 & 0.93 & 38 & 153 & 1.8 & & 9.2 \\
\hline 13 & 63.5 & 194 & 0.87 & 36 & 155 & 1.8 & & 17.5 \\
\hline 14 & 81,8 & 217 & 0.80 & 34 & 153 & 2.0 & & 10.6 \\
\hline 15 & 67.6 & 203 & 0.81 & 38 & 155 & 1.6 & & 10.6 \\
\hline 16 & 61.0 & 195 & 0.82 & & & & & 20.1 \\
\hline 17 & 101.0 & 231 & 0.82 & & & & & 13.6 \\
\hline 13 & 38.4 & 164 & 0.87 & & & & & 13.5 \\
\hline 19 & 78.8 & 210 & 0.85 & & & & & 11.5 \\
\hline 20 & 95.2 & 230 & 0.78 & $\cdot$ & & & & 13.2 \\
\hline 21 & 52.4 & 185 & 0.83 & & & & & 11,8 \\
\hline 22 & 53.3 & 188 & 0,80 & & & & & 16.2 \\
\hline 23 & 58.7 & 189 & 0.87 & & & & & 11.1 \\
\hline 24 & 65.8 & 197 & 0.86 & & & & & 11.5 \\
\hline 25 & 42.4 & 173 & 0.82 & & & & & 10.1 \\
\hline 26 & 58.0 & 193 & 0.81 & & & & & 13.3 \\
\hline 27 & 61.7 & 198 & 0.79 & & & & & 17.9 \\
\hline 28 & 49.3 & 179 & 0.86 & & & & & 13.7 \\
\hline 29 & 55.0 & 193 & 0.77 & & & & & 14.9 \\
\hline 30 & 57.7 & 195 & 0.78 & & & & & 16,5 \\
\hline & $64 \pm 15.6$ & $197 \pm 16$ & $0.82 \pm 0.04$ & $36 \pm 2$ & $156 \pm 2.5$ & $1.4 \pm 0,4$ & & $13,4+3,2$ \\
\hline
\end{tabular}




\section{Group 8 Pond 38 05-24-83}

\begin{tabular}{|c|c|c|c|c|c|c|c|c|}
\hline & $\begin{array}{l}\text { Weloill } \\
\text { (g) }\end{array}$ & $\begin{array}{l}\log (10) \\
\text { l. }\end{array}$ & $\begin{array}{c}k \\
\text { foctor }\end{array}$ & $\begin{array}{l}\text { HCt } \\
(z)\end{array}$ & $\begin{array}{l}\text { Plosmo Nat } \\
\text { (mEE/C) }\end{array}$ & $\begin{array}{l}\text { P.losmo } \mathrm{K}^{+} \\
\text {(mEg/l) (umoies }\end{array}$ & $\begin{array}{l}\text { GIII ATPOse Activl } \\
\text { ATP hydrolyzed/nig }\end{array}$ & $\begin{array}{l}\text { ty } \\
\text { Droteln/hr) }\end{array}$ \\
\hline & & & $\ldots$ & & $\cdots \cdot$ & 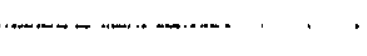 & $\cdots \cdots+\cdots$ & $\cdots \cdots$ \\
\hline 1 & 57.3 & 192 & 0.81 & 33 & 157 & 1.4 & 9.9 & \\
\hline 2 & 119.6 & 240 & 0.87 & 36 & 163 & 1.5 & 10.1 & \\
\hline 3 & 34.0 & 171 & 0.68 & 32 & 160 & 2.0 & 8.1 & \\
\hline 4 & 75.1 & 209 & 0,82 & 38 & 162 & 0,9 & 8.4 & \\
\hline 5 & 67.7 & 203 & 0.81 & 40 & 160 & 1.6 & 14.6 & \\
\hline 6 & 62.9 & 207 & 0.71 & 35 & 156 & 2.1 & 12.3 & \\
\hline 7 & 66.9 & 204 & 0.79 & 35 & 161 & 1.3 & 8.8 & \\
\hline 8 & 75.4 & 203 & 0.90 & 38 & 160 & 1.7 & 6.8 & \\
\hline 9 & 64.0 & 198 & 0.82 & 37 & 159 & 1.9 & 9.0 & \\
\hline 10 & 68.9 & 197 & 0.90 & 41 & 154 & 0.8 & 16.0 & \\
\hline 11 & 65.6 & 202 & 0.80 & 32 & 157 & 2.2 & 9.2 & \\
\hline 12 & 84.6 & 217 & 0.83 & 34 & 158 & 1.8 & 9.5 & \\
\hline 13 & 54.4 & 190 & 0.79 & 36 & 160 & 1.6 & 14,3 & \\
\hline 14 & 95.4 & 226 & 0.83 & 38 & 159 & 1.2 & 16.4 & \\
\hline 15 & 70.7 & 203 & 0.85 & 40 & 157 & 1.4 & 12.6 & \\
\hline 16 & 79.1 & 211 & 0.84 & 35 & 153 & 1.5 & 9,2 & \\
\hline 17 & 66.4 & 199 & 0.84 & & & & 10,2 & \\
\hline 13 & 79.3 & 206 & 0.91 & & & & 11.2 & \\
\hline 19 & 122.7 & 248 & 0.80 & & & & 11.8 & \\
\hline 20 & 71.3 & 212 & 0.75 & & & & 15.1 & \\
\hline 21 & 63.1 & 197 & 0.83 & & & & 14.4 & \\
\hline 22 & 53.2 & 181 & 0.90 & & & & 10.6 & \\
\hline 23 & 65.6 & 199 & 0.83 & & & & 8.7 & \\
\hline 24 & 59.0 & 194 & 0.81 & & & & 8.8 & \\
\hline 25 & 43,8 & 174 & 0.83 & & & & 7.3 & \\
\hline 26 & 66.1 & 200 & 0.83 & & & & 7.2 & \\
\hline 27 & 81.7 & 218 & 0.79 & & & & 6.3 & \\
\hline 28 & 65.1 & 198 & 0.84 & & & & 9.0 & \\
\hline 29 & 66.0 & 203 & 0.79 & & & & 18.5 & \\
\hline \multirow[t]{2}{*}{30} & $\begin{array}{r}59.3 \\
-\cdots\end{array}$ & $\begin{array}{l}197 \\
\ldots \ldots .\end{array}$ & $\begin{array}{l}0.78 \\
\ldots \ldots\end{array}$ &. & $-\cdots-\cdots$ & -.- & 8.4 & \\
\hline & $70.1 \pm 18.2$ & $203 \pm 16$ & $0.82 \pm 0.05$ & $36 \pm 3$ & $158 \pm 3$ & $1,6 \pm 0,4$ & $10,8 \pm 3,2$ & \\
\hline
\end{tabular}




\section{APPENDIX B}

The incidence

of

R. salmoninarum

in

Indfvidual Steelhead Trout

Prior to Rel ease 
Group 1 Pond 28 04-20-83

1. 0

2. 0

3. 0

4. 0

5. 0

6. 0

7. 0

8. 0

9. 0

10. 0

1. 0

2. 0

3. 0

4. 0

5. 0

6. 0

7. 0

8. 0

9. 0

10. 0
11. 0

12. +1

13. 0

14. 0

15. 0

16. 0

17. 0

18. 0

19. +1

20. 0

$$
+1=3 / 30(10.0 \%)
$$

Group 2 Pond 40 04-29-83

11. 0

12. 0

13. 0

14. 0

15. 0

16. +1

17. 0

18. +1

19. +1

20. 0

$+1=4 / 30(13.3 \%)$
21. 0

22. 0

23. 0

24. 0

25. 0

26. 0

27. 0

28. 0

29. +1

30. 0
21. 0

22. +1

23. 0

24. 0

25. 0

26. 0

27. 0

28. 0

29. 0

30. 0 
Group 3 Pond 36 05-02-83

1. 0

2. 0

3. 0

4. 0

5. 0

6. 0

7. 0

8. 0

9. 0

10. +1
11. +1

12. 0

13. 0

14. 0

15. 0

16. 0

17. 0

18. 0

19. 0

20. 0

$$
+1=3 / 30(10.0 \%)
$$

21. +1

22. 0

23. 0

24. 0

25. 0

26. 0

27. 0

28. 0

29. 0

30. 0 


\section{Group 4 Pond 34 05-19-83}

1. 0

2. 0

3. 0

4. +1

5. 0

6. 0

7. 0

8. 0

9. +1

10. 0

11. 0

12. 0

13. 0

14. 0

15. 0

16. 0

17. 0

18. +1

19. 0

20. 0
21. 0

22. 0

23. 0

24. +1

25. 0

26. +1

27. 0

28. 0

29. 0

30. 0

31. 0

32. 0

33. 0

34. 0

35. 0

36. 0

37. +1

38. 0

39. 0

40. 0
41. 0

42. 0

43. +1

44. 0

45. 0

46. 0

47. 0

48. 0

49. 0

50. 0

51. 0

52. 0

53. 0

54. 0

55. 0

56. 0

57. 0

58. 0

59. +1

60. 0

$$
+1=8 / 60(13.3 \%)
$$


Group 5 Pond $30 \quad$ 04-20-83

1. 0

2. +1

3. 0

4. 0

5. 0

6. 0

7. 0

8. 0

9. +1

10. 0

1. +1

2. +1

3. 0

4. 0

5. 0

6. 0

7. 0

8. +1

9. 0

10. 0
11. 0

12. 0

13. 0

14. 0

15. +1

16. 0

17. 0

18. 0

19. 0

20. 0

$+1=5 / 30(16.7 \%)$

Group 6 Pond 32 04-18-83

11. 0

12. 0

13. 0

14. 0

15. 0

16. 0

17. 0

18. 0

19. 0

20. 0

$+1=4 / 30(13.3 \%)$

3-40
21. 0

22. 0

23. 0

24. 0

25. 0

26. 0

27. 0

28. +1

29. 0

30. +1
21. 0

22. 0

23. +1

24. 0

25. 0

26. 0

27. 0

28. 0

29. 0

30. 0 


\section{Group 7 Pond 42 05-02-83}

1. 0

2. 0

3. 0

4. 0

5. 0

6. 0

7. +1

8. 0

9. 0

10. 0

1. 0

2. 0

3. 0

4. 0

5. 0

6. 0

7. 0

8. 0

9. 0

10. +1
11. 0

12. 0

13. 0

14. 0

15. 0

16. 0

17. 0

18. +1

19. 0

20. 0

$$
+1=4 / 30(13.3 \%)
$$

Group 8 Pond 38 05-18-83

11. 0

12. 0

13. +1

14. 0

15. 0

16. 0

17. 0

18. 0

19. 0

20. 0

$$
+1=2 / 30(6.7 \%)
$$

21. 0

22. 0

23. 0

24. 0

25. 0

26. +1

27. 0

28. 0

29. +1

30. 0
21. 0

22. 0

23. 0

24. 0

25. 0

26. 0

27. 0

28. 0

29. 0

30. 0 


\section{APPENDIX C}

Summary of Fish Health

Examinations by Joseph $C_{\text {, Lientz }}$ 
NMFS - 1983

Fish Health Exams

01-18-83 - Pre-mark exams

STT from all groups appeared to be in good health. Only light parasite loads of Gyrodactylus, Epistyzis, and Ichthyopthimius were noted. Light to moderate fin erosion was observed. Some debris was noted in the gills but stress was not apparent.

03-02-83 - Pre-release exams

STT appear to be in good condition. Light parasite loads were observed. Dorsal fin erosion was more apparent. Gills showing more swelling and more obvious extension beyond the opercle. Short rod bacteria were noted and more debris was present.

03-18-83

Same as 03-02-83, but moderate to heavy dorsal erosion and gill swelling noted. More external changes of smoltification being observed.

04-04-83

Fish look good. No stresses indicated and very light parasite loads observed.

04-19-83

Fish in very good condition. No stresses.

04-29-83

Still very good. No stresses.

05-24-83

Fish with light external parasite loads (GyrodactyZus and Epistyzis). Fins - dorsal erosion approximately 25 percent (moderate); gills good. Smolt appearance.

Throughout the rearing period January 1983 through May 1983 the steelhead in the marked groups appeared to be in good health. No undue stress conditions were noted. There was an indication that the parasite load was reduced, gill condition improved and overall health improved with the lower temperatures after 04-04-83. It would again appear that these are some of the better STT produced in the history of Dworshak NFH. 


\title{
APPENDIX D
}

Histological observations in select tissues of 1983 steelhead trout smolts reared at the Dworshak National Fish Hatchery.

\author{
by \\ Charlie E. Smith \\ and \\ John K. Morrison
}


HISTOLOGICAL OBSERVATIONS IN SELECT TISSUES OF 1983 STEELHEAD TROUT SMOLTS REARED AT THE OWORSHAK NATIONAL FISH HATCHERY

BY Charlie E. Smith \& John K. Morrison, USF\&WS, Bozeman Fish Cultural Development Center, Bozeman, Montana 59715

\section{INTRODUCTION}

The following report was prepared as part of an overall fish health examination to determine the well being of select groups of marked steelhead trout smolts reared at the Dworshak National Fish Hatchery during 1982-1983.

\section{OBJECTIVE}

The objective of this study was, by use of histological technique, to determine the condition of select tissues of steelhead trout smolts prior to their release from the Dworshak National Fish Hatchery.

METHODS

A histological examination of gills, kidneys, liver and nasal epithelium was conducted on 150 steelhead trout sampled during late April - early May $(4 / 20,4 / 29,5 / 2 \& 5 / 4)$ and 90 smolts collected in mid and late May $(5 / 19 \& 5 / 24) 1983$.

Tissues were dissected from anesthetized fish and preserved in Bouin's fixative by Dworshak personnel. Samples were then sent to the Bozeman FCDC where they were processed for histological. examination. Paraffin sections were cut at $5 \mu \mathrm{m}$ and stained with hematoxylin and eosin-phloxine.

\section{RESULTS}

Gizls

In general gills of the majority of smolts collected during late April - early May showed considerable hypertrophy (swelling) of lamellar epithelium (Fig 1) as well as mild diffuse necrosis of epithelium covering gill lamellae (Fig 2). Scattered fusion of some gill lamellae was also apparent, but was considered to be mild as were focal areas of edema and 
inflammation located at the bases of lamellae in a few fish. Seperation of gill lamellar epithelium from underiying basement membrane was apparent in the majority of fish. Most of this, however, appeared to be artifact. Neither parasitic nor bacterial infections were observed in any of the fish.

Gills from smolts collected in mid-late May appeared to be in extremely good condition (Figs $3 \& 4$ ). Occasionally, fusion and clubbing of lamellae at the tips of some filaments was seen ( $F i g$ ), but this was the exception rather than the rule.

Nasal epithelium

Considerable edema and mild diffuse necrosis of nasal sensory epithelial cells were a common finding in a large number of fish sampled in late April - early May (Fig 6). In addition, copious amounts of mucus was being secreted by increased numbers of goblet (mucus secreting) cells in some of the smolts. Sloughed necrotic cells could sometimes be seen in the secreted mucus (Fig 7).

Nasal epithelium of smolts sampled in mid and late May was generally in good condition (Fig 8) and other than occasional focal areas of edema, none of the other changes mentioned above were apparent. Livers

Liver tissue from all of the fish examined was essentially normal. There was very little cytoplasmic vacuolation in hepatocytes so typical of what is normally seen in hatchery fish and indicative primarily of reduced glycogen storage. This, however, may be normal for smolting steelhead.

Kidneys

Kidneys from all fish sampled were also essentially normal. There was some mild swelling of kidney tubule epithelium and occasionally, hydropic vacuolation. Such changes were very mild and only noted occasionally. 
CONCLUSION

Based upon histological examination of gills and nasal epithelium of fish examined in later April - early May one can assume that these fish were not healthy. The fact that tissues from fish sampled in mid to late May were normal may be related to the management practice of switching from reused water to raw water with a reduced temperature.

This inturn reduces the metabolic loading of the hatchery thereby reducing feeding rates and metabolite production, both of which may aid in repair of damaged tissues.

The fungus infections noted in nasal capsules of downstream migrants in the past may have been due to the release of smolts having similar degenerative changes in nasal epithelium that have been demoristrated in this report. Such changes, along with physiological and environmental stresses would make the smolts more susceptible to fungal infection. 
LEGEND TO FIGURES

Figure 1. Gill section from smolt collected $4 / 20 / 83$ showing hypertrophy (swelling) of gill lamellar epithelium, $x 1100$.

Figure 2. Hypertrophy and mild diffuse necrosis (arrows) of gill epithelium of fish sampled $4 / 20 / 83, \times 1100$.

Figure 3. Section of normal gill from smolt collected 5/24/83, X 175 .

Figure 4. High power view of some gill lamellae shown in Figure 3 , $\times 1100$.

Figure 5. Fusion and clubbing of gill lamellae at tip of filaments from smolt collected 5/19/83, X 175 .

Figure 6. Focal areas of edema with some necrosis (arrows) in nasal epithelium of smolt collected $4 / 29 / 83, \times 450$.

Figure 7. Nasal epithelium of smolt collected $5 / 2 / 83$. Note necrotic epithelium (arrow) being sloughed into surrounding area containing mucus, $\times 450$.

Figure 8. Normal nasal epithelium representative of that of smolt collected $5 / 24 / 83, \times 450$. 

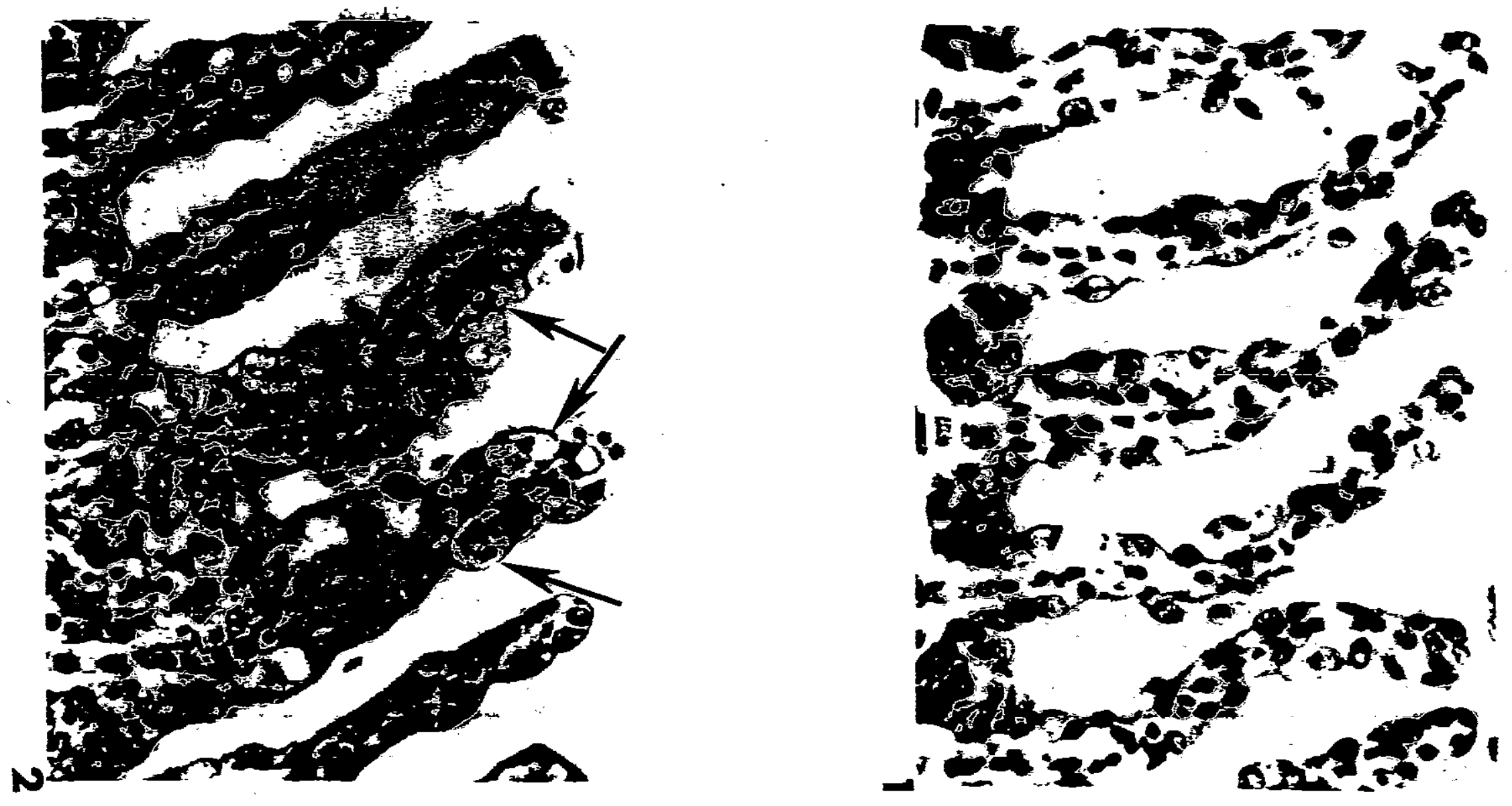

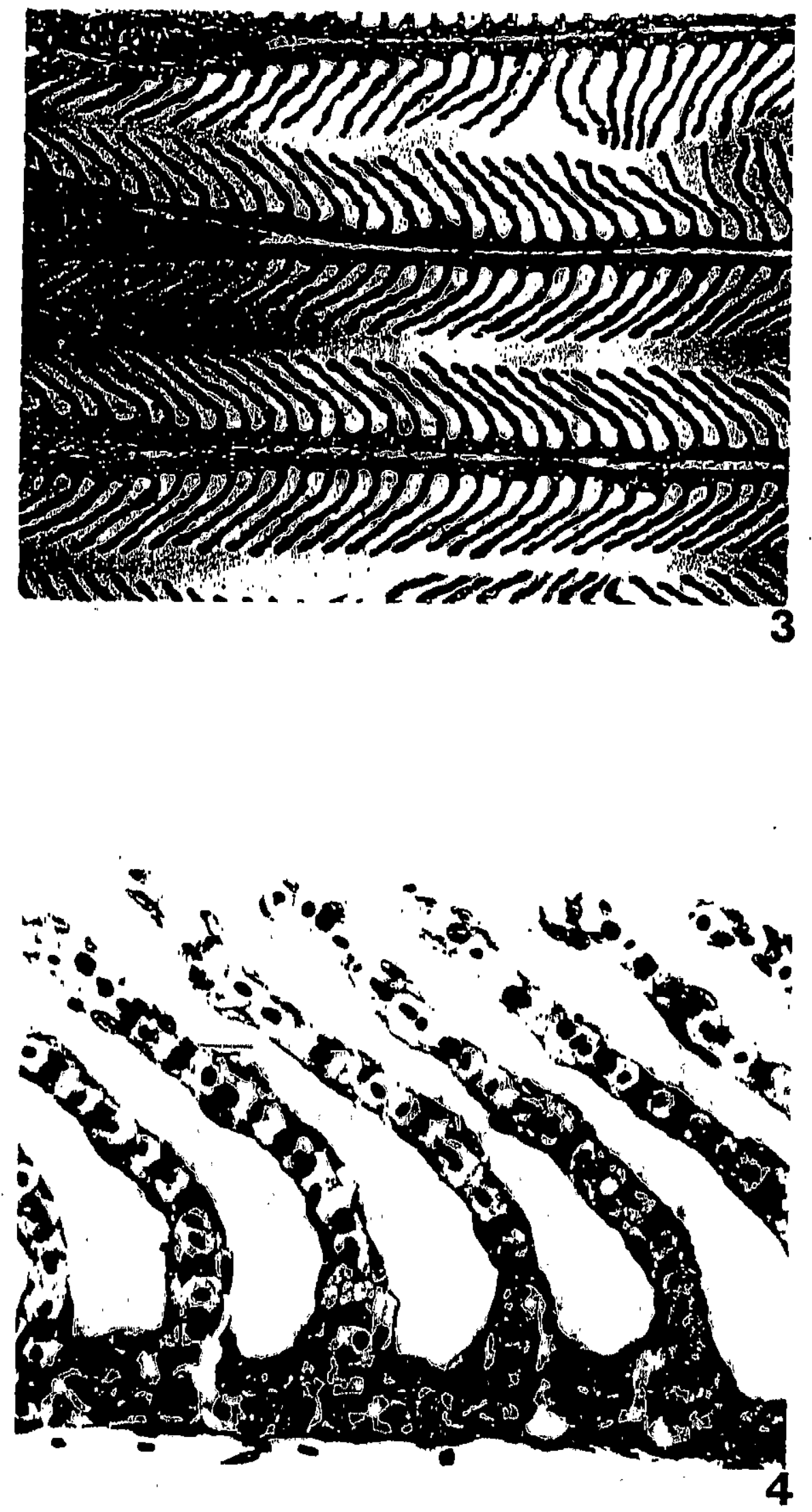

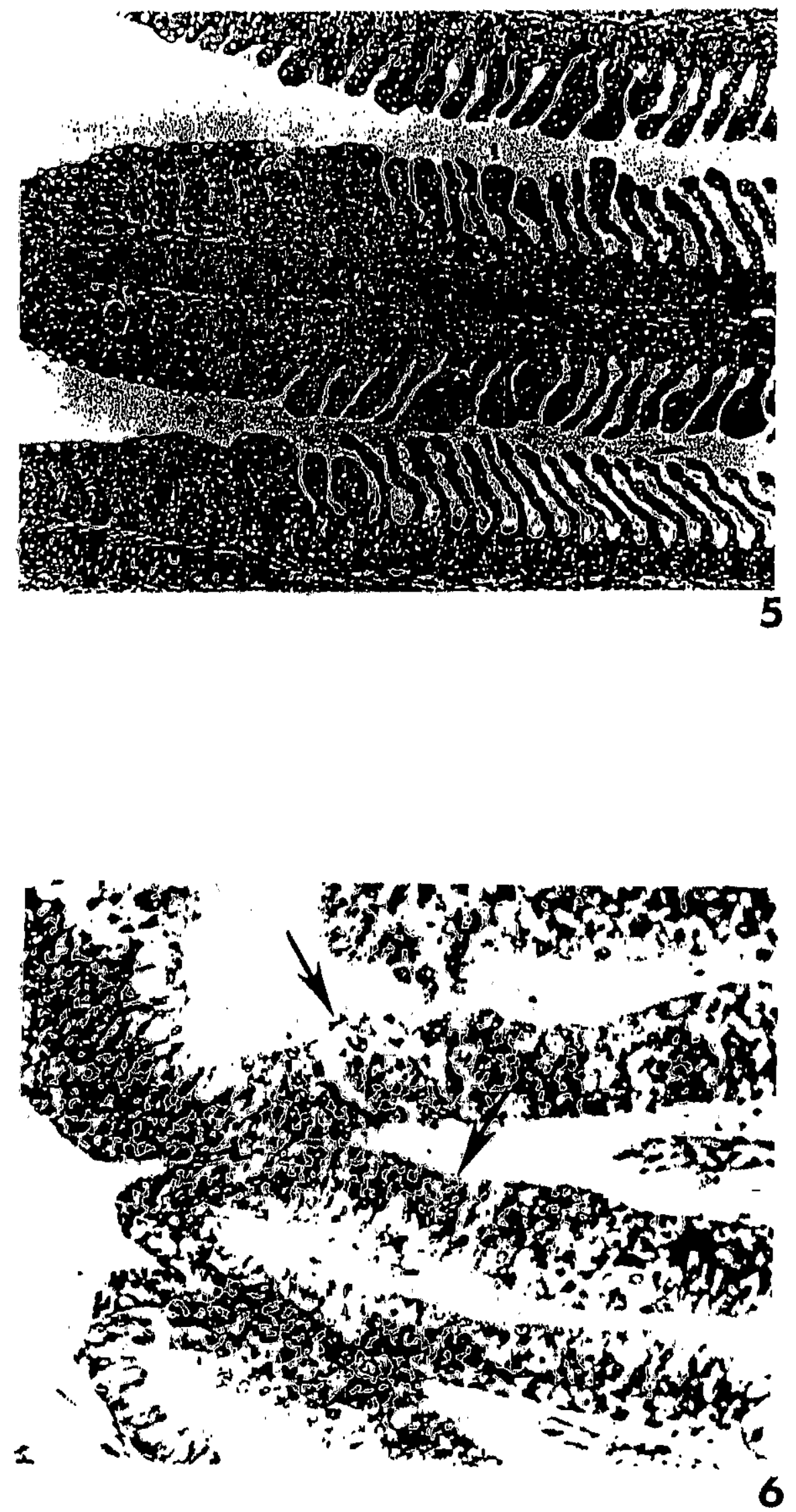

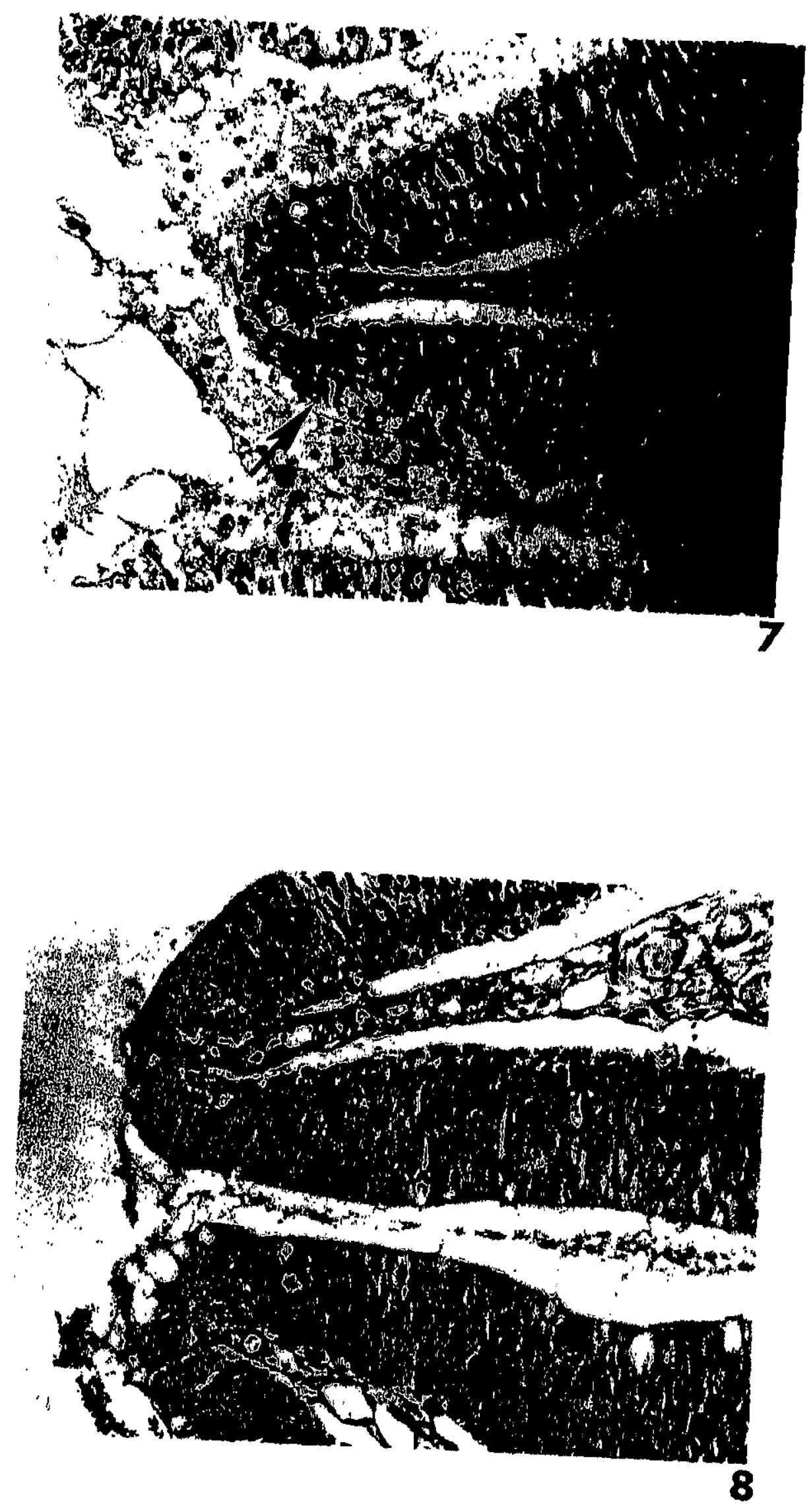